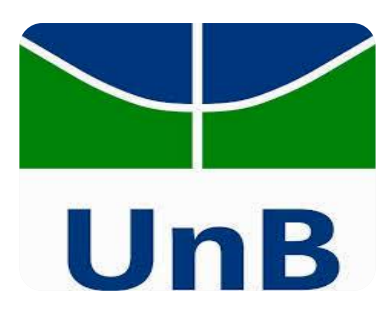

UNIVERSIDADE DE BRASÍLIA INSTITUTO DE FÍSICA

PROGRAMA DE PÓS-GRADUAÇÃO DE MESTRADO PROFISSIONAL EM ENSINO DE FÍSICA

MESTRADO NACIONAL PROFISSIONAL EM ENSINO DE FÍSICA

MODELAGEM TEÓRICA E EXPERIMENTAL DA DINÂMICA DE CORPOS RÍGIDOS EM SUPERFÍCIES COM ATRITO APLICADA AO ENSINO DO CONCEITO DE ENERGIA E SUAS TRANSFORMAÇÕES

Maria da Penha de Laia 


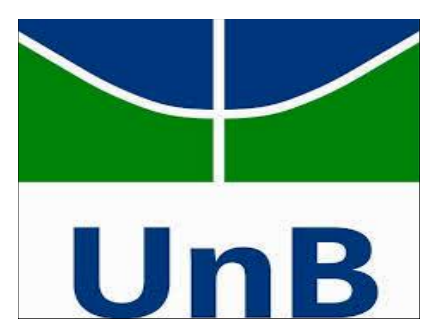

UNIVERSIDADE DE BRASÍLIA

INSTITUTO DE FÍSICA

PROGRAMA DE PÓS-GRADUAÇÃO DE MESTRADO PROFISSIONAL EM ENSINO DE FÍSICA

MESTRADO NACIONAL PROFISSIONAL EM ENSINO DE FÍSICA

\section{MODELAGEM TEÓRICA E EXPERIMENTAL DA DINÂMICA DE CORPOS RÍGIDOS EM SUPERFÍCIES COM ATRITO APLICADA AO ENSINO DO CONCEITO DE ENERGIA E SUAS TRANSFORMAÇÕES}

\section{Maria da Penha de Laia}

Dissertação de Mestrado apresentada à Banca Examinadora da Universidade de Brasília (UnB), como exigência parcial para a obtenção do título de Mestre em Ensino de Física, sob a orientação do professor Dr. Antony Marco Mota Polito.

Brasília-DF 
dD334m de Laia, Maria da Penha

MODELAGEM TEÓRICA E EXPERIMENTAL DA DINÂMICA DE CORPOS RÍGIDOS EM SUPERFÍCIES COM ATRITO APLICADA AO ENSINO DO CONCEITO DE ENERGIA E SUAS TRANSFORMAÇÕES / Maria da Penha de Laia; orientador Antony Marco Mota Polito. -Brasília, 2015. 149 p.

Dissertação (Mestrado Profissional em Ensino de Física) -Universidade de Brasília, 2015. 1. Ensino de física. 2. Aprendizagem significativa. 3. Energia: conservação, transformação e dissipação. 4. Experimentos educacionais. 5. Movimentos de translação e rotação acoplados. I. Polito, Antony Marco Mota, orient. II. Título. 


\section{AGRADECIMENTO}

À Deus, pela proteção e força divina.

À minha família, pela compreensão e companheirismo.

Ao meu filho, Mateus Laia, pela ajuda e paciência em vários trabalhos relacionados à tecnologia.

Ao professor e orientador, Antony Marco Mota Polito, por fazer deste trabalho um campo aberto de ensinamento, transformando cada encontro em um belíssimo evento educativo. Sou muito grata por ter sido meu professor orientador, aprendi muito com você.

A todos os professores e colegas do mestrado, por terem contribuído muito para que fosse possível mais esta conquista.

Aos professores de física, Charles e Mário, que tanto contribuíram para mais esta conquista.

À professora Dra. Maria de Fátima Verdeaux, pela atenção e acompanhamento.

À CAPES, pela contribuição financeira.

À Sociedade Brasileira de Ensino de Física (SBF) pela realização do Mestrado Nacional Profissional em Ensino de Física.

Ao Instituto de Física da Universidade de Brasília (UnB) pela excelente acolhida. 
Agradeço todas as dificuldades que enfrentei; não fosse por elas, eu não teria saído do lugar. As facilidades nos impedem de caminhar. Mesmo as críticas nos auxiliam muito.

Chico Xavier. 


\section{SUMÁRIO}

Resumo

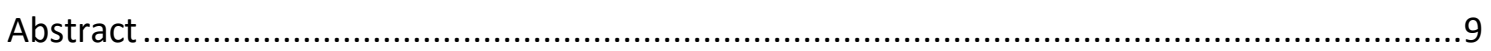

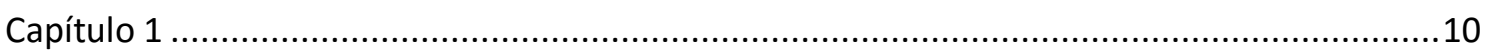

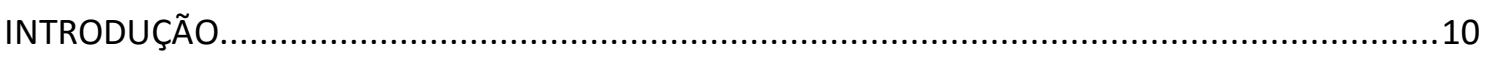

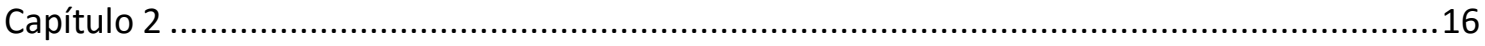

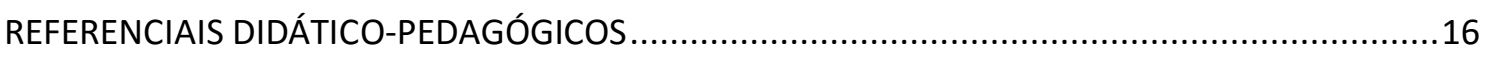

2.1. O papel da matemática no ensino da física..................................................................16

2.2. A teoria de aprendizagem significativa de David Ausubel............................................19

2.3. A teoria de educação de Joseph Novak ......................................................................22

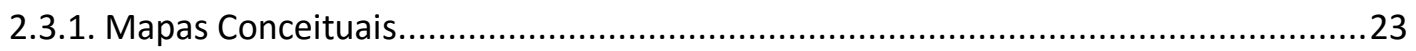

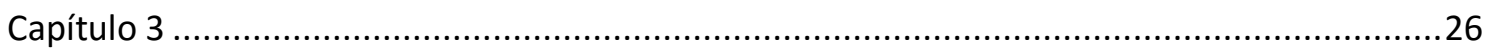

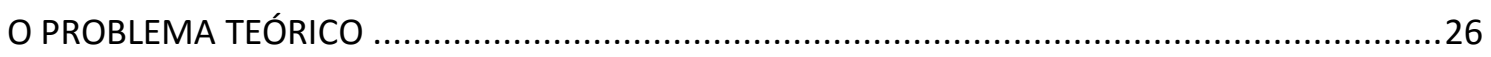

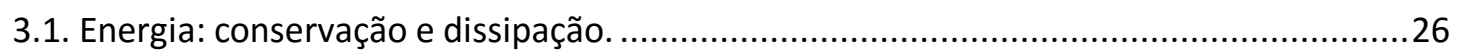

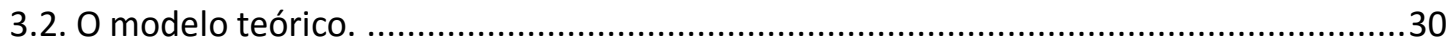

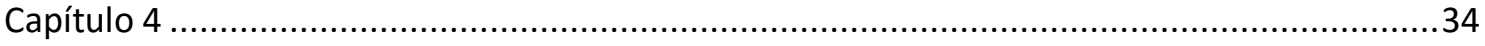

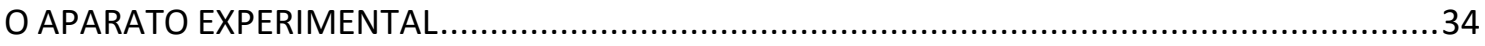

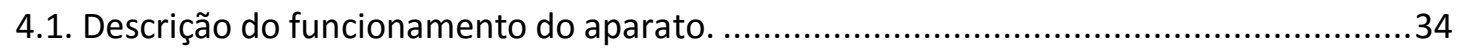

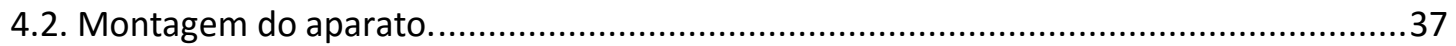

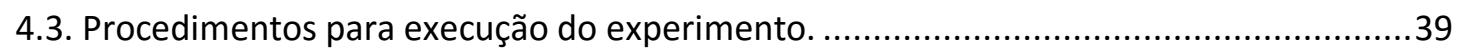

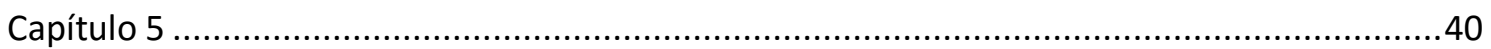

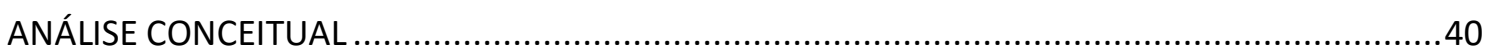

5.1. Medições necessárias para efetuar a interpretação......................................................40

5.2. Análise conceitual do fenômeno: panorama............................................................. 41

5.3. Análise conceitual do fenômeno: detalhamento............................................................4

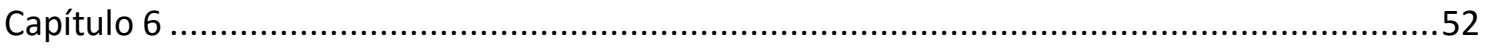

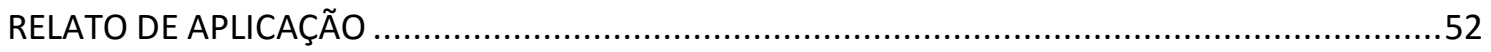

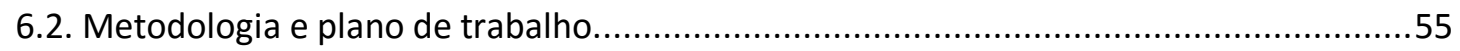

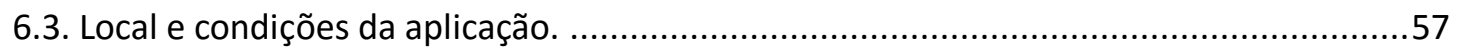

6.4. Etapas da aplicação e sequência de aprendizagem. ......................................................60

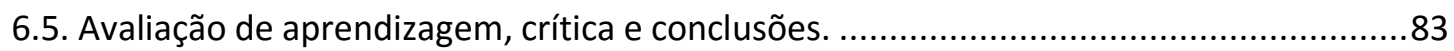

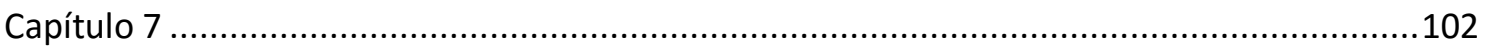




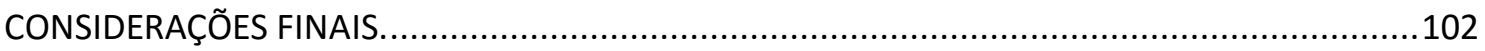

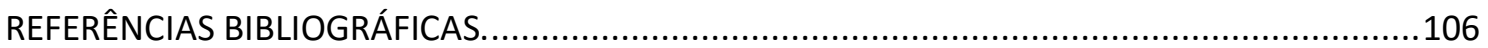

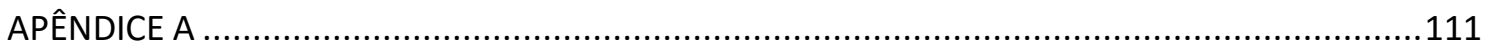

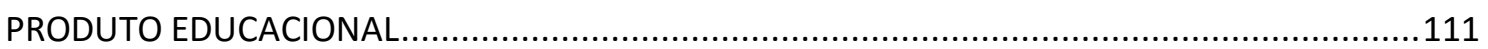

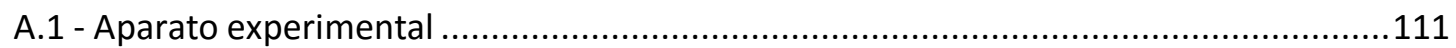

A.1.1 - Descrição do funcionamento do aparato. .............................................................111

A.1.2 - Descrição dos materiais utilizados......................................................................114

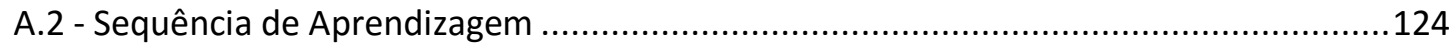

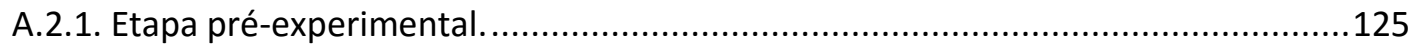

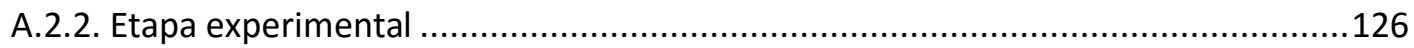

A.2.3. Etapa de análise do experimento....................................................................133

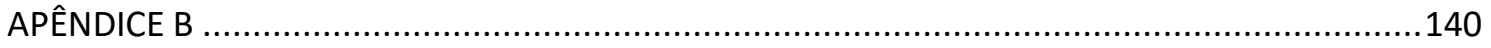

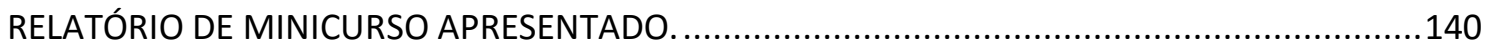




\section{LISTA DE FIGURAS.}

Figura 1: estrutura de mapa conceitual. 25

Figura 2: estrutura e conteúdo de mapa conceitual. .................................................. 25

Figura 3: esquema de forças na barra girante sobre superficie com atrito. .................. 30

Figura 4: coordenadas cartesianas para a barra girante.......................................... 31

Figura 5: coordenadas generalizadas para a barra girante....................................... 32

Figura 6: esquema de forças em um carro sobre superfície com atrito. ...................... 33

Figura 7: carrinho, eixo rotor, ferrolho e trajetórias traçadas pelo carrinho. ..................3 37

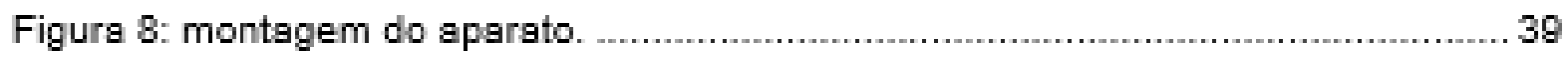

Figura 9: Instituto de Salinas. Fonte: arquivo do IFNMG ...........................................60

Figura 10: mapa do norte de Minas Gerais. ............................................................ 60

Figura 11: mapas conceituais feitos pelos alunos (pré-teste) .....................................64

Figura 12: mapas conceituais feitos pelos alunos (pré-teste). ......................................65 65

Figura 13: mapas conceituais feitos pelos alunos (pré-teste). ...................................66

Figura 14: alunos fazendo medidas e construindo tabelas. ......................................69

Figura 15: alunos analisando trajetórias descritas pelo carrinho................................ 71

Figura 16: alunos discutindo as tarefas do guia 3.................................................... 79

Figura 17: aparato em funcionamento e registro de algumas trajetórias. .....................80

Figura 18: trajetória analisada no exemplo......................................................... 81

Figura 19: outra trajetória descrita pelo carrinho ...................................................... 81

Figura 20: mapas conceituais produzidos pelos alunos. $\dot{A}$ direita: pós-teste. $\dot{A}$

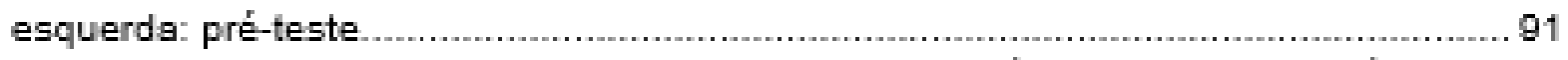

Figura 21: mapas conceituais produzidos pelos alunos. $\mathrm{A}$ direita: pós-teste. $\dot{A}$

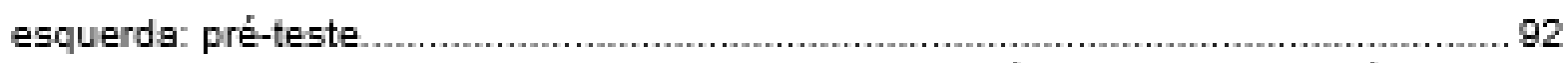

Figura 22: mapas conceituais produzidos pelos alunos. $\dot{A}$ direita: pós-teste. $\dot{A}$

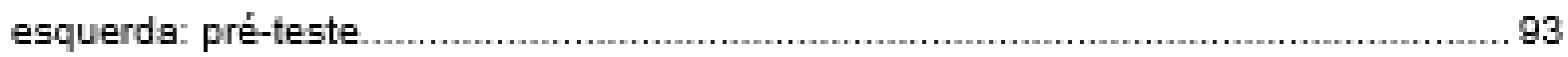

Figura 23: mapas conceituais produzidos pelos alunos. $\dot{A}$ direita: pós-teste. $\dot{A}$ esquerda: pré-teste.

Figura 24: mapas conceituais produzidos pelos alunos. $\dot{A}$ direita: pós-teste. $\dot{A}$

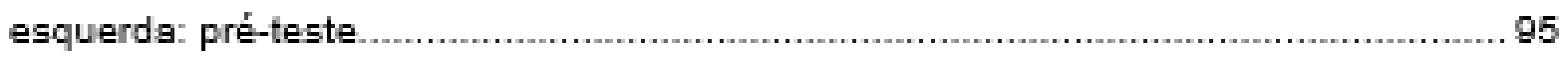

Figura 25: mapas conceituais produzidos pelos alunos. $\dot{A}$ direita: pós-teste. $\dot{A}$

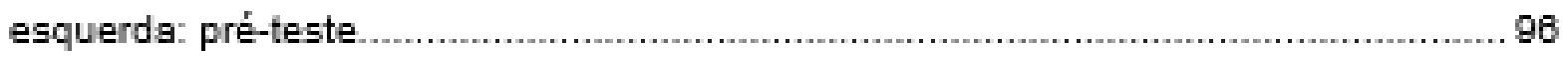

Figura 26: mapas conceituais produzidos pelos alunos. $\dot{A}$ direita: pós-teste. $\dot{A}$ esquerda: pré-teste.

Figura A-1: carrinho, eixo rotor, ferrolho e trajetória traçada pelo carrinho. ................ 114

Figura A-2: partes do aparato experimental: 1-carrinho e 2-eixo rotor........................ 119

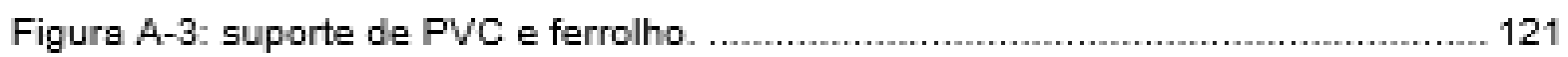

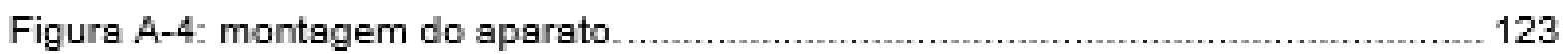

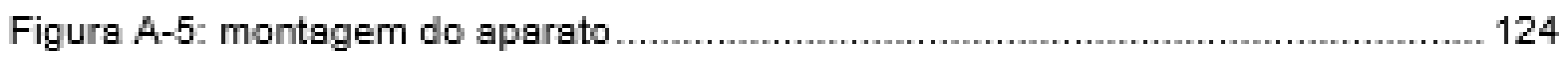

Figura B-1: apresentaçäo do arranjo experimental no IFNMG-Salings...................... 142

Figura B-2: atividades dos participantes do minicurso. ............................................. 143 


\section{Resumo}

Nesse trabalho, apresentamos o desenvolvimento e a construção de um aparato experimental e de uma sequência de aprendizagem para realizar um estudo do conceito de energia e de suas transformações utilizando a dinâmica de um corpo rígido deslizando sobre uma superfície com atrito. $\mathrm{O}$ aparato consiste em um dispositivo capaz de lançar um disco de madeira munido de quatro pontos de apoio sobre uma superfície plana, em movimento combinado de rotação e translação. O movimento de rotação é produzido pela conversão de energia potencial gravitacional, estocada em um peso suspenso, enquanto 0 movimento de translação é produzido pela conversão de energia potencial elástica, estocada em uma mola. Ao final de cada ensaio, uma trajetória desenhada sobre a superfície é analisada para avaliar o princípio de conservação da energia mecânica e as perdas energéticas por atrito por meio da superfície e das partes móveis do aparato. Para uma avaliação qualitativa do desempenho da estratégia, foram utilizados mapas conceituais. Esse produto educacional foi aplicado no Instituto Federal Norte de Minas Gerais - Campus Salinas, para uma turma do primeiro ano do Ensino Médio. Acreditamos que esse produto tem grande potencial para enriquecer não apenas as aulas relacionadas com o tema "energia e suas transformações", mas todas as demais aulas de mecânica. Ele possibilita, ainda, estudar o impacto que a introdução de aparatos experimentais, manipuláveis diretamente pelo aluno, permite alcançar na melhoria da aprendizagem significativa de conceitos básicos da mecânica, integrando de forma mais efetiva os conceitos e suas definições matemáticas. A estratégia utilizada para a aplicação desse trabalho visou uma participação ativa dos estudantes na construção dos conceitos, na manipulação do experimento e na execução de medidas.

Palavras-chave: Dinâmica de Corpos Rígidos; Energia Mecânica; Energia Potencial; Energia Cinética; Trabalho; Forças de Atrito; Princípio de Conservação da Energia; Dissipação de Energia; Aprendizagem Significativa; Mapas Conceituais; Ensino de Física. 


\begin{abstract}
In this work, we present the development and construction of an experimental apparatus and a sequence of learning to conduct a study of the concept of energy and its transformations using the dynamics of a rigid body sliding on a surface with friction. The apparatus consists of a device capable of launching a disc of wood supported by four points upon a flat surface, in a combination of rotational and translational movement. The rotational motion is produced converting gravitational potential energy, stored in a suspended weight, while the translational motion is produced converting elastic potential energy stored in a spring. At the end of each trial, a trajectory drawn on the surface is analyzed to assess the principle of conservation of mechanical energy and the energy losses through the forces of friction produced both by the surface and by the movable parts of the apparatus. For a qualitative assessment of the strategy, we used conceptual maps. This educational product was applied at the Instituto Federal do Norte de Minas Gerais - Campus Salinas, for a first year high school class. We believe that this product has great potential to enrich not just the classes related to the theme "energy and its transformations", but all other classes of mechanics. It also allows to study whether the introduction of experimental apparatus, directly manipulated by the students, allows to improve meaningful learning of basic concepts of mechanics, integrating more effectively the mathematical concepts and their definitions. The strategy used for the application of this work aimed at the active participation of the students in the construction of concepts, in the handling of the trial and execution of measurements.
\end{abstract}

Palavras-chave: Rigid Body Dynamics, Mechanical Energy; Potential Energy; Kinetic Energy; Work; Forces of Friction; Principle of Energy Conservation; Dissipation of Energy; Meaningful Learning; Conceptual Maps; Teaching of Physics. 


\section{Capítulo 1}

\section{INTRODUÇÃO}

Ao longo de minha experiência como docente, atuando nas áreas de ciências, matemática e física, nas esferas municipal, estadual e federal, do Estado de Minas Gerais, pude constatar que os conceitos físicos, quando ensinados apenas teoricamente, sem apelo a situações de caráter concreto e/ou prático, tendem a ser aqueles que os alunos menos têm condições de aprender. Por vezes, mesmo sendo capazes de executar as atividades propostas pelo professor, os alunos não conseguem organizar e integrar os conteúdos a serem aprendidos.

Segundo a teoria de aprendizagem devida a David Ausubel, a chamada aprendizagem significativa só acontece quando os novos conceitos são apresentados em contextos de aprendizagem que interajam de maneira específica e suficientemente adequada com a estrutura cognitiva dos indivíduos, de tal forma que os conceitos que Ihes são prévios possam servir de alicerce para a construção dos novos conceitos. Ainda segundo Ausubel, quando esta interação não acontece ou acontece deficientemente, é possível que a aprendizagem se dê de modo meramente mecânico, tendendo a não perdurar, ou seja, não proporcionando uma alteração da estrutura conceitual já cristalizada (MOREIRA, 1999, 2012).

Mesmo instâncias menos elaboradas de aplicação dessas ideias já sugerem uma suposição natural: a de que situações física e vivencialmente concretas, mas conceitualmente ricas, quando apresentadas em sala de aula, proporcionam um certo conjunto de condições adequadas que, ainda que não sejam, elas próprias, inteiramente suficientes, parecem ser necessárias para qualquer tipo de aprendizagem significativa. De fato, não há dúvidas de que, em contextos concretos e instigantes, os alunos costumam ter maiores oportunidades - e, principalmente, necessidades - de aprender a construir esquemas, medir grandezas físicas, utilizar instrumentos, analisar resultados encontrados com o auxílio de expressões matemáticas e, por fim, utilizar 
diferentes linguagens e símbolos para alcançar uma compreensão teórica adequada de sua experiência (SÉRÉ, COELHO, NUNES, 2003).

Ainda mais especificamente, é natural supor que o aprendizado de técnicas de investigação experimental, em conexão com avaliações conceituais quantitativas, possibilite um olhar mais crítico e integrado sobre os fenômenos físicos, favorecendo a construção de relações entre os referentes empíricos, os conceitos, as leis e as teorias (DE MELLO ARRUDA, 1993). A hipótese de fundo é, portanto, que a utilização de situações experimentais no ensino de física é capaz de potencializar a aquisição integrada de conceitos físicos, seja nos seus aspectos qualitativos, seja nos aspectos quantitativos, o que ajuda os estudantes a efetivarem uma aprendizagem verdadeiramente significativa. Segundo Ausubel, o aprendiz toma posse, desse modo, de significados claros, precisos, diferenciados e transferíveis (AZEVEDO et al, 2009; BORGES, 2002; SERÉ, COELHO, NUNES, 2003; TAMIR, 1991; WHITE, 1996; DE ARAÚJO, DOS SANTOS ABIB, 2003; DOS SANTOS, 2007).

Muito embora tal hipótese de base pareça natural, contudo, o método tradicional, com aulas exclusivamente teóricas, desvinculadas não apenas de práticas concretas, mas também do quotidiano do aluno, ainda é adotado por boa parte dos docentes. Esse pode ser o principal motivo para o desinteresse, a evasão e o baixo rendimento que vêm sendo observados em sala de aula, principalmente na área da física (DE ARAÚJJ, DOS SANTOS ABIB, 2003). Evidentemente, essa constatação não afasta a importância de outros fatores tais como a falta de equipamentos básicos necessários ao bom desempenho da prática docente, as salas de aula com elevado número de alunos, os baixos salários dos docentes, associados à sua carga horária estafante (ZIBAS, 2013). Sem estudos mais amplos e profundos, é impossível avaliar o papel relativo desses fatores e demonstrar quais deles são preponderantes. É até mesmo possível - e até provável - que haja uma correlação entre eles. Entretanto, em vista das dificuldades de se atacar os demais problemas - e até que se prove que somente a solução conjunta de todos eles seria capaz de alterar substancialmente o quadro da educação em ciências, no Brasil - é interessante 
investigar que tipos de ação podem ser levadas à cabo, individualmente, para melhorar a abordagem dos conteúdos científicos em sala de aula.

Essas constatações e reflexões valem para todos os níveis da educação. Porém, infelizmente, no Brasil, o Ensino Médio é considerado a pior etapa da Educação Básica. De acordo com dados do Ministério da Educação (MEC), 970 mil jovens de 15 a 17 anos estão fora da escola (TOKARNIA, 2013). Os resultados do IDEB (Índice de Desenvolvimento da Educação Básico) de 2013, por exemplo, apontaram uma média de 3,7 pontos, abaixo da meta, que era de 3,9 pontos. Segundo o então Ministro da Educação, Henrique Paim, isso se deveu ao fato de que as políticas voltadas a esse nível de ensino eram recentes, já que o Ensino Médio apenas se tornou responsabilidade plena dos Estados e Municípios a partir de 2011, com o FUNDEB (Fundo Nacional de Desenvolvimento da Educação). A discussão sobre os problemas do Ensino Médio está aberta (EDUCAÇÃO, 2014). É consenso que precisamos adquirir hábitos novos, romper rotinas, dialogar e investigar as necessidades das novas escolas, embora não pareça haver consenso em como esses novos hábitos serão alcançados (KAWAMURA e HOSOUME, 2003).

Em suma, a proposta de produto pedagógico apresentada nessa dissertação parte de perspectivas didático-pedagógicas específicas, mas razoavelmente aceitas, e de um diagnóstico parcial (e informal) da situação encontrada nas salas de aula. Ou seja, parte da ideia de que uma das possibilidades de se contribuir para uma participação mais ativa do aprendiz na construção de seu próprio conhecimento encontra-se em sua imersão em contextos física e vivencialmente concretos, porém, conceitualmente ricos. Esses e outros elementos envolvendo referenciais teóricos didático-pedagógicos serão apresentados com um pouco mais de detalhes no Capítulo 2.

Em consonância com a ideia geral esboçada, propomos a utilização de aparatos experimentais que permitam não apenas a mera demonstração de um fenômeno, mas que possam ir além: permitam e exijam sua manipulação direta, por parte do aluno, com vistas a aprofundar sua compreensão não apenas qualitativa, mas, principalmente, quantitativa. Pensando especificamente no estudante do primeiro ano do Ensino Médio, focalizamos o trabalho em torno do 
problema do ensino do conceito de energia e de suas transformações. Para tanto, elaboramos e construímos uma situação de aprendizagem envolvendo a utilização de um aparato experimental para estudar a dinâmica de corpos rígidos em superfícies com atrito, um tema relativamente pouco explorado, mesmo no contexto da mecânica ensinada nos cursos superiores de física, porém, de bastante apelo intuitivo e prático.

Muitos são os objetivos que se pode alcançar, com esse tipo de abordagem. Em primeiro lugar, o estudo e a avaliação do impacto real causado pela introdução de aparatos experimentais manipulados diretamente pelo aluno na melhoria da aprendizagem significativa de conceitos básicos da mecânica. Esse objetivo mais geral pode e deve ganhar uma instância ulterior: a análise do possível impacto positivo da manipulação experimental no sentido de integrar, de forma mais efetiva, a partes qualitativa e quantitativa dos conceitos físicos, ou seja, seus referentes intuitivos e suas definições matemáticas formais. Evidentemente, um objetivo colateral, mas igualmente importante, é verificar se a introdução de situações de aprendizagem envolvendo contextos fisicamente concretos é capaz de tornar as aulas de físicas mais interessantes, interativas e (potencialmente) voltadas para o quotidiano e as vivências do aluno.

Para implementar a proposta baseada na hipótese assumida e dar oportunidade de verificar a real possibilidade de se alcançar ao menos alguns dos objetivos citados, elaboramos uma situação experimental que, esperamos, seja capaz de ilustrar os aspectos gerais acima mencionados. Essa situação experimental guarda relação direta com um problema prático, amplamente relacionado com vivências quotidianas dos alunos: o problema de um carro cujo motorista perdeu o seu controle e entra em processo de derrapagem. Nesse problema, observa-se comumente que os carros traçam com suas rodas (no asfalto ou na terra) trajetórias curvas que são o resultado de uma combinação de movimentos de rotação e de translação.

Resumidamente, nosso aparato consiste de um disco (um "carrinho") que, inicialmente, encontra-se acoplado a um eixo rotor, ambos suspensos verticalmente. $O$ conjunto formado pelo carrinho e pelo eixo rotor entra em movimento de rotação a partir da ação de um cabo (fio fino) em cuja extremidade encontra-se um peso suspenso. $O$ peso é solto de uma determinada altura e 0 
carrinho desacopla-se do eixo rotor quando o peso atinge o fim de seu curso. $O$ carrinho cai sobre uma superfície horizontal, girando, e, nesse exato instante, recebe um impacto horizontal de um dispositivo que possui uma energia potencial elástica estocada (um "ferrolho" dotado de uma mola). O resultado esperado é uma dinâmica, envolvendo o acoplamento dos movimentos de rotação e translação, cuja trajetória é registrada na superfície por onde o móvel deslizou. É a forma e, principalmente, o comprimento total desse percurso que devem ser analisados para servir de base para o desenvolvimento de boa parte das discussões que estarão presentes na sequência didática. A situação concreta esboçada tem potencial para apresentar grande quantidade de conceitos de mecânica de forma integrada, tais como: posição, trajetória, velocidade, velocidade angular, força de atrito, energia potencial, energia cinética, dissipação, coeficiente de elasticidade, etc. O problema teórico envolvido na descrição da dinâmica será apresentado, muito brevemente, no Capítulo 3. O detalhamento das partes, das funções e da montagem do aparato experimental será efetuada no Capítulo 4.

Com o objetivo de utilizar o aparato em uma situação específica de aprendizagem, elaboramos uma sequência didática apropriada e a aplicamos em uma turma do primeiro ano do Ensino Médio do Instituto Federal do Norte de Minas Gerais (IFNMG) - Campus de Salinas. Os objetivos específicos que procuramos alcançar através do uso dessa sequência didática foram os seguintes. Em primeiro lugar, fazer com que os estudantes tomassem um primeiro contato com os conceitos de energia, suas transformações e suas dissipações de uma forma completamente qualitativa, por meio de explicações concretamente exemplificadas por meio da demonstração do funcionamento do aparato. Em seguida, procurar fazer com que estruturassem o conhecimento teórico com base na intuição prática do assunto, inclusive pela assimilação de expressões matemáticas cuja justificação foi (e deve ser) devidamente postergada. $O$ objetivo seguinte consiste em fazer com que os estudantes realizem ensaios que produzam trajetórias cuja análise permita verificar o papel que as forças de atrito desempenham na dissipação das energias mecânicas potenciais. Para realizar esses ensaios e ter acesso aos dados relevantes, os estudantes têm, à sua disposição, diversas escolhas de parâmetros físicos. 
Todos esses parâmetros devem ser medidos por eles mesmos e utilizados na medida de sua necessidade para a compreensão quantitativa dos processos de transformação da energia. De qualquer modo, talvez o mais importante a ser destacado na utilização deste tipo de experimentos "problematizadores" é a busca por uma discussão em torno dos conteúdos, visando explorar o assunto relacionado com a adequação dos modelos ideais quando aplicados a situações reais (AZEVEDO et al, 2009). Vale ressaltar que a sequência didática apresentada é apenas um modelo. Caberá sempre ao professor montar outras sequências de acordo com os conteúdos e os objetivos que deseje atingir.

Os detalhes da sequência didática e da análise conceitual que a acompanha são apresentados no Capítulo 5. No Capítulo 6, apresentamos o relato da aplicação e seus resultados. No Capítulo 7, apresentamos nossas considerações finais.

Faz parte desse trabalho uma descrição completa e detalhada do produto educacional. Ela é apresentada no Apêndice A. Para facilitar a confecção e a utilização do material pelos docentes, preparamos um roteiro detalhado da construção do aparato experimental. Completa o produto educacional uma proposta de sequência de aprendizagem envolvendo o tema "energia e suas transformações".

No Apêndice B, apresentamos o relato de um minicurso ministrado para os professores sobre o produto educacional, no evento II SELFIS (Semana da Licenciatura em Física), ocorrido no Instituto Federal do Norte de Minas Gerais. 


\section{Capítulo 2}

\section{REFERENCIAIS DIDÁTICO-PEDAGÓGICOS}

Neste capítulo, abordaremos, de forma breve e sucinta, algumas teorias de aprendizagem que podem ser utilizadas como fundamento para as estratégias de desenvolvimento e aplicação deste trabalho. Porém, antes, teceremos alguns importantes comentários críticos que julgamos ser de importância capital para o entendimento dos objetivos que quisemos alcançar no desenvolvimento desse projeto.

\subsection{O papel da matemática no ensino da física.}

No contexto específico do Ensino Médio, um dos problemas mais frequentemente citados, entre aqueles que parecem ser cruciais para o baixo desempenho dos alunos, refere-se ao domínio dos conhecimentos matemáticos que alicerçam os conteúdos de física a serem ensinados. Segundo PIETROCOLA $(2002,2008)$, por exemplo, é fundamental que a física seja ensinada de uma forma integrada com a matemática da qual ela faz uso, uma vez reconhecido o papel fundamentalmente estruturante que a matemática desempenha na construção dos conceitos e das teorias físicas (WIGNER, 1960; YEATTS, HUNDHAUSEN, 1992; ZAHAR, 1980). À princípio, esse papel estruturante deveria ser cuidadosamente diferenciado do papel puramente instrumental que certas partes da matemática desempenham nas teorias físicas, principalmente, na sua aplicação (exemplos e problemas a serem resolvidos).

Contudo, a ênfase nos aspectos estruturantes, em detrimento dos instrumentais, deve ser um pouco melhor compreendida e analisada. De fato, embora seja suficientemente clara essa divisão de papéis no contexto da apresentação das teorias físicas em nível mais sofisticado - por exemplo, no ensino superior -, não é completamente claro de que modo o papel estruturante pode ser enfatizado ou evidenciado quando o nível de apresentação dos conceitos da física é tal que as suas teorias ainda não podem ser suficientemente descritas ou articuladas, justamente por serem os conceitos matemáticos 
estruturantes de nível muito mais elevado. À título de ilustração desse fato, podemos citar o caso da mecânica newtoniana. Seus conceitos fundamentais (espaço, tempo, velocidade, aceleração, massa, força, quantidade de movimento, etc.) são apresentados já no primeiro ano do Ensino Médio. Porém, é evidente que a matemática de fato minimamente necessária para estruturar a mecânica newtoniana, a saber, o cálculo diferencial e integral, a teoria de equações diferenciais ordinárias e o cálculo vetorial, não apenas não é ensinada nesse nível, como dificilmente o poderia ser, uma vez dados os vínculos atuais dos currículos do ensino básico.

Essa realidade não deveria ser, entretanto, um impedimento na busca de uma mais profunda integração entre matemática e física, no contexto do ensino (MALVERN, 2000; GINGRAS, 2001; MILLAR, 1991; THOMPSON, THOMPSON, 1994). É fundamental que o aluno de Ensino Médio perceba que, mesmo no nível mais elementar da definição dos conceitos, do estabelecimento das suas múltiplas relações de equivalência e conversibilidade - sempre fundamentadas em princípios gerais, tais como os princípios de conservação (ex.: energia potencial que se converte integralmente em cinética) - e de sua aplicação imediata em contextos simplificados de medida e interpretação de medidas, a física não pode ser nem compreendida, nem realizada, sem o uso extensivo da matemática.

Nesse sentido, a análise realizada por Pietrocola parece apontar na direção certa, ainda que o foco deva ser modificado. Em particular, é verdade que a mera utilização da matemática como ferramenta na solução de problemas teóricos não parece contribuir muito para que os alunos que estudam física no Ensino Médio consigam compreender o seu verdadeiro papel. Embora essa compreensão só possa ser verdadeiramente alcançada se as teorias mais sofisticadas thes forem apresentadas - no caso de virem a seguir carreiras técnico-científicas - não é impossível, contudo, que pelo menos parte dela seja alcançada ainda no Ensino Médio, permitindo que os estudantes que seguirão por outras profissões - ou mesmo aqueles que encerrarão seus estudos possam entender essa íntima conexão entre física e matemática. Com relação aos demais, não é preciso nem mesmo enfatizar a importância desse aspecto, 
tanto no que se refere à formação de futuros físicos, como também de futuros engenheiros, químicos, arquitetos e outros profissionais de nível superior.

Por outro lado, o próprio ensino da matemática, desde as primeiras séries do ensino fundamental, é realizado de tal maneira que os alunos, na sua grande maioria, não conseguem perceber seu propósito ou enxergar seu conteúdo concreto. Assim, se, por um lado, o professor de física alega que o problema dos alunos está na sua deficiência em matemática, por outro, o professor de matemática geralmente não aceita que sua disciplina seja vinculada a objetivos mais concretos e aplicados.

Muito embora o problema pareça ser de difícil solução, acreditamos que uma saída viável seja justamente prestar mais atenção aos contextos concretos, quer na acepção física do termo, quer na sua acepção vivencial. Nesse sentido, quaisquer estratégias didáticas que sejam capazes de fazer o aluno utilizar-se efetivamente da matemática, enquanto tratam de problemas de física, são extremamente bem-vindas. Esses contextos concretos não podem, contudo, ser contextos de mera ilustração. Se o professor de física, por exemplo, apenas se limitar a apresentar um aparato experimental para demonstrar a existência de um fenômeno físico ou ilustrar um conceito, dificilmente a conexão estreita entre a matemática e a física poderá ser evidenciada. Pelo contrário, a ilustração pode passar a impressão oposta, de que a física pode ser compreendida com nenhum apelo à matemática. É bastante possível que a maneira mais fácil e eficiente de efetuar essa conexão de maneira bem-sucedida seja concentrar-se no papel precípuo que a matemática desempenha não exatamente na física teórica, mas na experimental, ou seja, na realização e na interpretação de procedimentos de medida e na descrição das relações de equivalência entre conceitos.

É mais ou menos claro o modo como essas conexões podem ser realizadas, em um processo "pendular" contínuo, mas crescente. Inicialmente, de posse de um conhecimento conceitual preliminar e "intuitivo", o aluno opera medidas (ou seja, realiza operações matemáticas) sobre um aparato experimental utilizando-se, preferencialmente, de instrumentos simples, tais como réguas, transferidores, cronômetros, termômetros, dinamômetros, balanças, etc. Não é preciso que o aluno entenda completamente toda a física que está por trás dos fenômenos observados, ou mesmo que conheça a 
definição formal dos conceitos físicos que estão em jogo. Contudo, é essencial que ele seja capaz de começar a interpretar formalmente, em símbolos de variáveis e em números, as medidas efetuadas. É nesse momento que o professor pode fazer uso realmente significativo dos conhecimentos de matemática elementar, como a geometria, a trigonometria e a aritmética. Em um segundo momento, já de posse de um modelo físico (conceitual) que possa prever (ou explicar) o fenômeno a ser observado - no todo, ou nas suas partes -, o professor encontra-se na oportunidade de fazer a conexão entre os conceitos físicos preliminarmente introduzidos e suas definições matemáticas, pois, muito geralmente, as medidas diretas servirão para, indiretamente, calcular outras quantidades físicas. É nesse momento que o uso significativo da teoria de funções elementares e da álgebra, por exemplo, pode ser realizado. Em um terceiro momento, a repetição das medidas, com a construção de tabelas e gráficos, novamente invoca significativamente o uso concreto de conceitos matemáticos, tais como médias, desvios-padrão e sistemas de coordenadas.

$O$ processo deve oscilar entre o qualitativo (intuição dos fenômenos) e o quantitativo (uso da matemática na estruturação dos conceitos) até que todo o conceito seja, finalmente, aprendido, em uma escala crescente de diferenciação conceitual. Note que não se trata de uma abordagem de aprendizagem por descoberta. Portanto, não é o caso de interpretá-lo como uma aplicação de teorias construtivistas. Cada processo particular deve ser guiado por uma sequência de aprendizagem específica, procedendo de uma estrutura geral para suas instâncias particulares. A esse respeito, convém já esclarecer que o processo é realizado algumas vezes no sentido de concretizar os elementos abstratos em passos suaves e gradativos, alternando aspectos qualitativos e quantitativos, não em uma espiral, propriamente dita, mas em uma escada em que cada passo qualitativo apoia-se em um passo quantitativo que, por sua vez, apoia-se em um qualitativo. Esse processo deve ser levado a cabo até o fim da particular sequência desenvolvida. Essa estratégia está alinhada com a teoria de aprendizagem de David Ausubel.

\subsection{A teoria de aprendizagem significativa de David Ausubel.}


A teoria de aprendizagem de Ausubel é, essencialmente, uma teoria cognitiva. Nela, a aprendizagem é considerada um processo de armazenamento organizado de informações na mente do indivíduo que aprende. A aprendizagem é sinônimo de organização e integração de conteúdos na mente. Apesar desse alto grau de generalidade, a teoria foi construída para ser aplicada à aprendizagem tal como ocorre em contextos educacionais (MOREIRA, 1999, 2012). Um de seus elementos conceituais mais importantes estabelece que a aprendizagem tem que ser baseada em conhecimentos prévios já acumulados pelos estudantes. Isso é coerente com uma perspectiva cognitivista, segundo a qual a organização e integração de novos conhecimentos deve dar-se, necessariamente, a partir de uma estrutura já previamente organizada, que adquiriu conteúdo e forma em razão de toda a história de aprendizagem, formal ou não, do indivíduo.

No contexto da aprendizagem na escola, isso significa que o professor tem que levar em conta conceitos que os alunos já adquiriram, pois os novos conceitos terão que, necessariamente, acomodar-se na mesma estrutura cognitiva, ou seja, devem encontrar o seu lugar dentro da estrutura total de ideias do indivíduo. Contudo, para além de mera acumulação de novas informações, a aprendizagem é um processo de interação entre os novos conceitos e a estrutura previamente organizada, implicando uma assimilação que modifica, a cada nova interação, toda a estrutura cognitiva prévia. Quando isso acontece, diz-se que a aprendizagem é significativa (AUSUBEL, 2000).

A assimilação de novos conteúdos envolvida na aprendizagem significativa é um processo hierarquizado, que não apenas requer a existência como implica a modificação do chamado conceito subsunçor. $O$ conceito subsunçor dirige o processo de aprendizagem na medida em que, sendo mais amplo e inclusivo, organiza a assimilação de novos conceitos - que devem ser, desse modo, necessariamente subordinados ao subsunçor. $O$ processo de subordinação, por sua vez, acarreta uma modificação estrutural no subsunçor antigo. Isso equivale, efetivamente, à criação de novos subsunçores.

Ao lado da aprendizagem significativa, há também um tipo de aprendizagem que Ausubel denominou por aprendizagem mecânica. Essa tem pouca ou nenhuma interação com conceitos relevantes previamente existentes 
na estrutura cognitiva do indivíduo e, pelo menos em princípio, armazena as novas informações de maneira arbitrária e literal. Isso, obviamente, compromete as ligações com subsunçores específicos, mas apenas no caso desses já existirem. A aprendizagem mecânica pode servir, desse modo, como base para a formação de novos subsunçores, sobretudo no início dos processos de aprendizagem. À medida que a aprendizagem começa a ficar mais sofisticada, ela vai passando a ser verdadeiramente significativa, passando esses novos subsunçores a cumprir o seu papel estruturante, servindo de alicerce para a assimilação de novas informações, dessa vez, de forma não-arbitrária e nãoliteral.

Uma maneira de facilitar os processos de criação de novos subsunçores ou de modificação de subsunçores já existentes é a utilização dos chamados organizadores prévios - materiais introdutórios, apresentados antes do conteúdo a ser aprendido, que servem de ponte entre o que o aprendiz já sabe e o que ele deve saber, e que apresentem razoável grau de generalidade e abstração. Os organizadores prévios atuam, portanto, como uma espécie de subsunçores externos - providos pelo professor ou pelo material didático - e que podem estruturar e catalisar a aprendizagem de novos conceitos e a formação de subsunçores (internos).

De acordo com Ausubel, as condições necessárias para a ocorrência de aprendizagem significativa não se restringem à condição de que o conteúdo a ser assimilado possa (e deva) ser relacionado com a estrutura cognitiva prévia do estudante de maneira não-literal e não-arbitrária, ou seja, de que o conteúdo seja potencialmente significativo. É preciso, também, que os estudantes manifestem uma disposição efetiva para relacionar-se com o conteúdo e com o material didático, de modo a incorporá-lo à suas estruturas cognitivas (MOREIRA, 1999).

Por fim, a teoria ausubeliana fornece suporte para a estratégia de ensino adotada na elaboração de nossa sequência de aprendizagem e na aplicação do nosso produto educacional. Isso porque nossa estratégia consiste em partir de uma estrutura conceitual provida externamente, pelo professor, que ordena os fenômenos observados, inicialmente, da forma mais "abstrata" possível (conceitos gerais, amplos, intuitivos, não-instanciados) para, em seguida, à 
medida que os passos da sequência se sucedem, tornar a estrutura gradativamente mais "concreta" (conceitos particulares, específicos, objetivos, instanciados). A estrutura conceitual ganha progressivamente essa concretude pela alternância da estruturação quantitativa e da estruturação qualitativa, as quais, por sua vez, são viabilizadas pelas operações ativas dos alunos, na manipulação do experimento. A importância dessa ideia de manipulação ativa, feita em conjunto, pelos alunos interagindo entre si, dentro de sala de aula, pode ser melhor compreendida no contexto da teoria de educação de Joseph Novak.

\subsection{A teoria de educação de Joseph Novak.}

A chamada teoria de educação de Joseph Novak pode ser considerada uma evolução da teoria de Ausubel. Muito embora Ausubel tenha reconhecido a importância dos elementos afetivos (além dos psicomotores) em sua teoria, é fato que seu foco eram os elementos puramente cognitivos. Para Novak, entretanto, uma teoria educativa deve considerar que os seres humanos, essencialmente, não apenas pensam, mas também sentem e atuam.

Levando, portanto, em consideração aspectos que vão além do puramente cognitivo e avançam na direção de teorias de aprendizagem sociais, Novak concebe os eventos educativos como ações que objetivam a troca de significados e sentimentos entre o estudante e o professor dentro de um contexto ou matriz social. Assim, significados são objetos conceituais socialmente compartilhados e a aprendizagem significativa deve ser um processo de assimilação desses objetos cuja validade é estabelecida dentro de uma comunidade específica de usuários que também compartilha valores, crenças, hábitos, costumes, em uma palavra: cultura.

A ideia central da teoria de Novak é, portanto, que a educação é um conjunto de experiências - eventos educativos, cujos constituintes básicos são o estudante, o professor, o conteúdo, o contexto social e a avaliação - cujo objetivo é o engrandecimento do indivíduo enquanto ser humano. Assim, a aprendizagem significativa é apenas parte de um processo mais amplo e deve ser tematizada como o elemento subjacente à integração entre pensamento, 
sentimento e ação, internamente ao indivíduo. Nesse sentido, percebe-se a importância de se levar em consideração também as vivências quotidianas dos alunos, nos eventos educativos.

Para facilitar a aprendizagem significativa, Novak destaca duas ferramentas de instrução: o mapa conceitual e o chamado "vê epistemológico" de Gowin (MOREIRA,1999). Uma parte de nosso interesse na teoria de Novak deve-se também ao fato de que os mapas conceituais foram efetivamente utilizados como recurso didático para avaliar os conceitos prévios dos estudantes de primeiro ano do Ensino Médio a respeito do tema energia e suas transformações, durante a sequência didática que dirigiu a aplicação do produto educacional desenvolvido. Esse recurso também foi utilizado na confecção e aplicação de testes posteriores, que visaram realizar uma estimativa (bastante aproximada) do grau de aprendizagem significativa alcançado com a aplicação do produto.

\subsubsection{Mapas Conceituais}

Mapas conceituais são diagramas que indicam relações significativas entre conceitos (figuras 1 e 2). Evidentemente, a ideia de se formar redes para exibir esquematicamente a estrutura de um campo conceitual é mais ou menos óbvia e não é nova. Pode-se até dizer que seus elementos remontam à Antiguidade, estando implícitos, por exemplo, no método dialético platônico (REALE, ANTISERI, 1990). Entretanto, Joseph Novak retomou, modernamente, a ideia no contexto de aplicação de sua teoria de educação e do cognitivismo ausubeliano, transformando-a em uma bem-sucedida ferramenta didática (NOVAK, GOWIN, 1984).

De sua própria definição, segue-se que mapas conceituais podem ser utilizados como organizadores prévios. Para além de aplicar regras simples de lógica e teoria de conjuntos, não há regras fixas para se construir mapas conceituais. Porém, uma forma estruturada para montá-los consiste em dispor hierarquicamente as ideias principais ao longo da vertical, de cima para baixo, segundo seu nível de generalidade, e, na horizontal, dispondo-os de tal forma que representem o mesmo nível de generalização e inclusão. No topo, aparecem 
os conceitos que englobam os outros e, na base, os que são englobados, incluindo-se, eventualmente, exemplos. Podemos interpretar o uso de um mapa conceitual como um método eficaz para "negociar significados", por serem representações visuais explícitas, mas abertas, dos conceitos e das proposições que um indivíduo possui, permitindo que alunos e professores troquem e avaliem esses significados mutuamente (MOREIRA, 1999, 2012).

Não há dúvidas de que esse é um instrumento didático que pode ser facilmente utilizado pelos professores em sala de aula e que tem potencial para influenciar na aprendizagem de maneira positiva. Da mesma forma que há bastante liberdade na sua construção, há, também, bastante liberdade no seu uso. O professor pode, por exemplo, utilizar o mapa como recurso instrucional para organizar e apresentar o conteúdo de sua aula, evidenciando, com isso, os organizadores prévios. É possível que o uso mais profícuo seja aquele que o próprio estudante pode fazer, uma vez que o esforço de construir mapas é, ele próprio, algo que, por um lado, requer entendimento e, por outro, constrói entendimento. É recomendável, contudo, que o professor guie os alunos através do mapa (ou de sua construção), utilizando-o, preferencialmente, quando os alunos já têm alguma familiaridade com o assunto.

Apesar dessa última recomendação, o professor também pode usar o mapa como instrumento de avaliação para investigar como os alunos organizam as informações que possuem sobre determinado assunto, seja previamente, seja posteriormente à apresentação do conteúdo. Assim, o professor tem condições de adquirir mais informações sobre como o aluno estrutura, diferencia e integra os conceitos referentes a determinado tema (MOREIRA, 1999, 2012). Com o uso prévio de mapas, o docente pode, inclusive, investigar e avaliar mudanças ocorridas durante o processo de construção do conhecimento, obtendo informações para realimentar a estrutura de ensino/aprendizagem. 


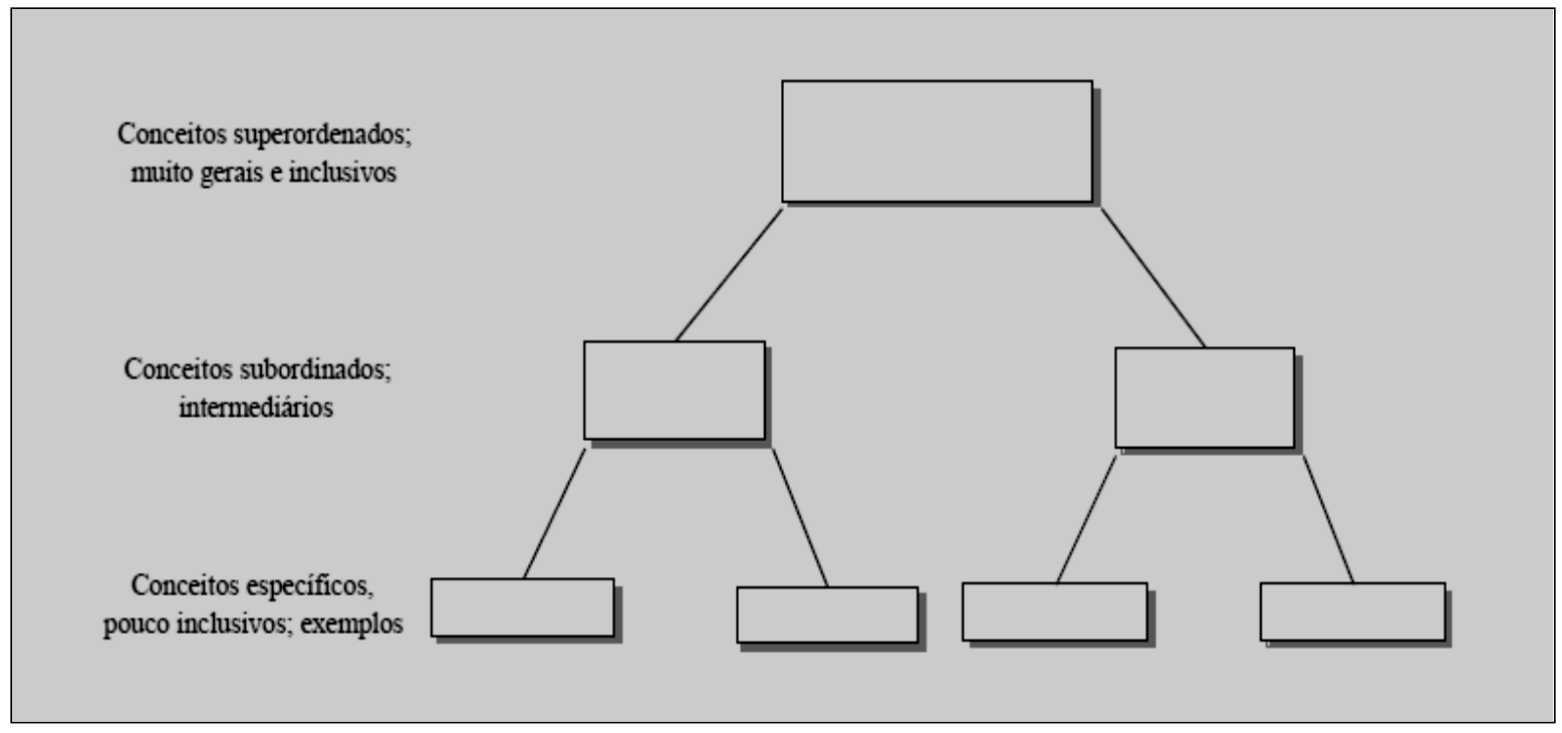

Figura 1: estrutura de mapa conceitual (MOREIRA, 2006, pág. 11).

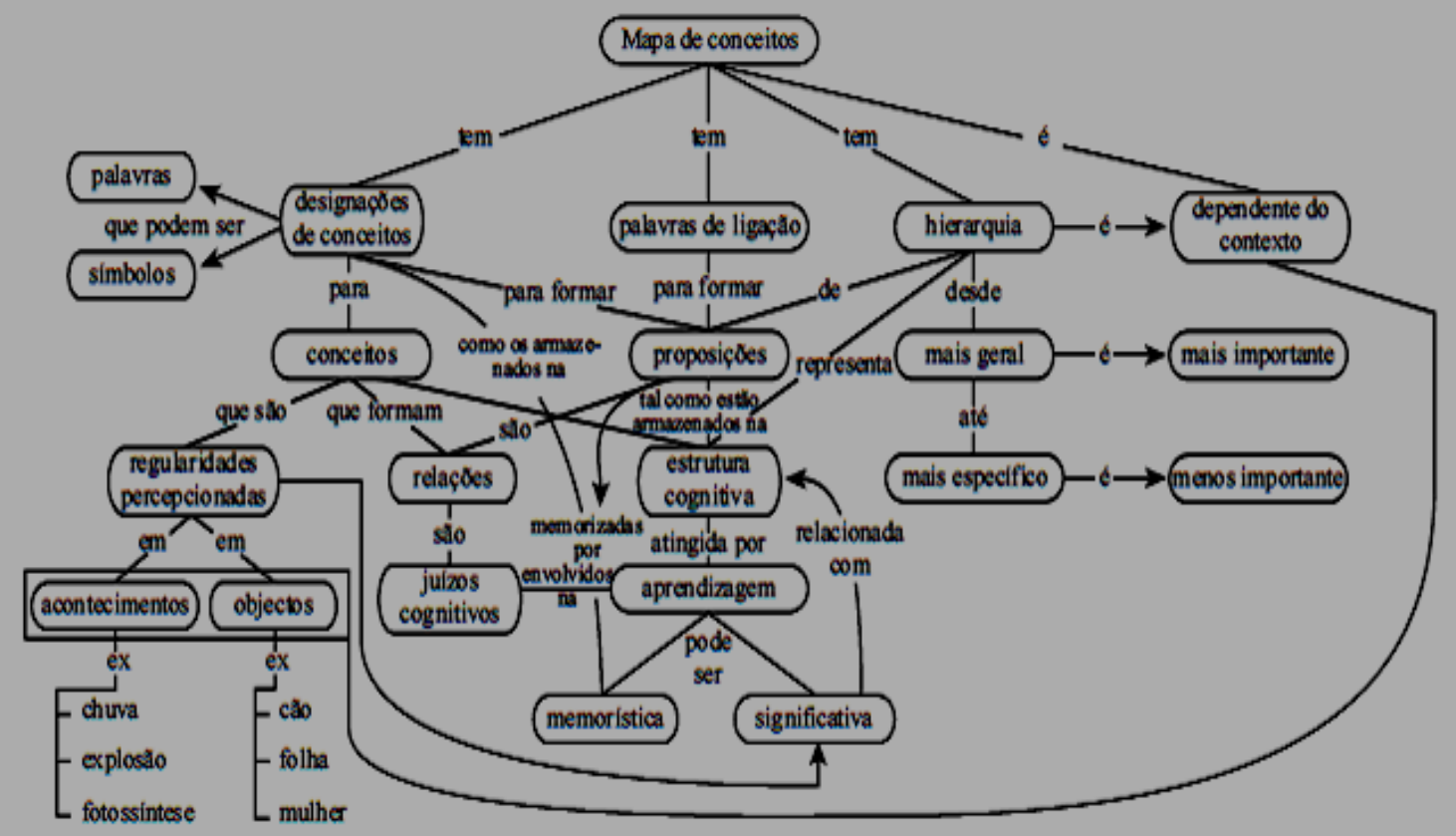

Figura 2: estrutura e conteúdo de mapa conceitual (NOVAK e GOWIN, 1984, pág. 30). 


\section{Capítulo 3}

\section{O PROBLEMA TEÓRICO}

Neste capítulo, abordamos os elementos teóricos necessários para a compreensão do fenômeno do deslizamento de um corpo rígido sobre uma superfície com atrito. Para tanto, faz-se necessário construir um modelo físico, ou seja, um modelo ideal (matemático) que julgamos ser suficiente para capturar todas as características mais fundamentais do fenômeno observado. Antes, porém, é interessante tecer breves comentários sobre os conceitos centrais que estão por detrás do fenômeno a ser observado, de seu modelo físico e das preocupações didáticas relativas a este trabalho: energia, conservação da energia e dissipação da energia.

\subsection{Energia: conservação e dissipação.}

O tema que envolve os conceitos de energia e suas transformações é central em muitos aspectos. Não é necessário nem mesmo enfatizar demasiadamente a importância que a energia possui para a vida moderna e as dificuldades envolvidas com sua produção, estocagem e distribuição em um mundo cada vez mais dependente economicamente de insumos dessa natureza. Não é o caso de se pensar, evidentemente, que isso seja uma novidade: o ser humano, como todo o resto do mundo vivo, sempre foi dependente de energia para sobreviver. O que mudou sensivelmente, do século XVIII para cá, foi a escala, já que, somente no século XX, a população mundial quadruplicou.

Em vista dessa importância e dos impactos altamente negativos que a escassez relativa de energia promete para o futuro, muita pesquisa aplicada tem sido realizada com o objetivo de descobrir e estudar estratégias que aumentem a eficiência e a economia dos muitos processos envolvendo a energia, seja em sua produção, seja no seu consumo. Nesse sentido, o problema mais pungente associado com os processos energéticos tem sido justamente aquele relacionado com a sua dissipação, ou seja, com a sua perda irreversível em processos termodinâmicos. 
Do ponto de vista educacional, é muito curioso que o aspecto mais enfatizado seja não o da dissipação, mas sim o da conservação da energia (SOBES, TARIN, 2004). Isso se deve ao evidente fato de que a física tem por fundamento princípios de conservação, pois todas as forças fundamentais da natureza são conservativas (BAPTISTA, 2006). Contudo, pode-se dizer, com um pouco de licença, que isso só é "válido" microscopicamente. Ainda que saibamos que a energia total de um sistema isolado, de fato, se conserva, no mundo macroscópico, em que vive o cidadão comum, pode-se dizer que a conservação da energia útil para realização de trabalho não é sequer uma exceção: ela, simplesmente, não existe.

A história do conceito de energia e de seu princípio de conservação é bastante recente. A história dos estudos experimentais e teóricos sobre a dissipação da energia, mais recente ainda. É possível localizar, contudo, alguns ancestrais mais remotos - e ilustres - dessa história. Christiaan Huygens foi, possivelmente, o primeiro a perceber, ainda na segunda metade do século XVII, que, nos processos elásticos de colisão unidimensional, a soma total das parcelas de $m v^{2}$, de cada corpo, era conservada, após a colisão (DUGAS, 1988).

Porém, foi o seu pupilo Gottfried W. Leibniz quem desenvolveu as consequências dessa descoberta. Primeiramente, ele demonstrou que essa quantidade - denominada por ele, posteriormente, de vis viva - era a verdadeira quantidade restaurada nos processos cíclicos envolvendo o movimento de objetos sob ação da gravidade, ao contrário da quantidade de movimento criada e defendida por René Descartes. Esse é um marco histórico do princípio de conservação da energia (mecânica), que ficou relativamente obscurecido, durante todo o século XVIII e parte do século XIX (WESTFALL, 1977; DUGAS, 1988; JAMMER, 1997, 1999).

Leibniz sabia, contudo, que para implementar completamente o princípio de conservação da vis viva, na dinâmica de impactos de Huygens, era necessário, em certos casos, conceber uma outra "força" que compensasse sua aparente perda. Ele criou, então, o conceito de "força elástica" (o que seria concebido, posteriormente, como energia potencial elástica). Ele concebeu a dinâmica de impactos de Huygens em termos energéticos e estendeu sua 
aplicação para corpos não-rígidos, definindo colisões elásticas como sendo aquelas que regeneravam completamente a vis viva e colisões inelásticas como aquelas que consumiam a vis viva. De forma ainda mais surpreendente, Leibniz, estendendo o conceito de conservação da vis viva para todos os processos da natureza, percebeu que a vis viva aparentemente perdida nas colisões inelásticas continuava indestrutível, subdividida internamente entre as partes menores das quais esses corpos eram compostos, antecipando, em mais de um século, o moderno conceito mecânico de calor (WESTFALL, 1977).

Leibniz considerava a energia o elemento físico fundamental do universo. A matéria passou a ser concebida, por ele, como sendo constituída por "centros de atividade" energética. Embora os físicos-matemáticos do século XVIII (Bernoullis, D’Alembert, Euler, Lagrange) tenham empregado o conceito de energia nas suas posteriores formulações da mecânica, esse conceito teria que esperar até o século XIX para sua completa matematização e aceitação como uma entidade fundamental (POLITO, POLITO, 2015; PURRINGTON, 1997).

Nesse meio-tempo, a física desenvolveu-se sob o escopo da mecânica newtoniana. O século XVIII foi, entretanto, também o período no qual os fenômenos envolvendo calor e eletricidade começaram a ser investigados experimentalmente. A física experimental foi, portanto, a porta de entrada que possibilitou a retomada da discussão sobre o conceito de energia e suas transformações.

Nesse aspecto, o estudo das relações entre calor e trabalho mecânico foi de importância central. Enquanto a física do século XVIII tinha considerado processos mecânicos e não-mecânicos como sendo essencialmente distintos, a demonstração da equivalência entre calor e trabalho mecânico, provida por James Joule, na década de 1840, estabeleceu a unificação dos processos térmicos e mecânicos. De fato, o princípio de Joule - acrescido à reformulação de Rudolf Clausius da teoria das máquinas térmicas de Sadi Carnot - forneceu a base para o desenvolvimento da termodinâmica. Trabalhando separadamente, William Thomson (Lord Kelvin) e Rudolf Clausius foram ambos responsáveis por assentar as bases da termodinâmica sobre fundamentos exclusivamente mecânicos, demonstrando que a equivalência entre calor e trabalho era 
consistente com a teoria do calor como movimento microscópico das partículas constituintes dos objetos macroscópicos (PURRINGTON, 1997).

Igualmente importante, contudo, foi a reconsideração da ideia de dissipação da energia, dessa vez associada à construção da segunda lei da termodinâmica. Enquanto Clausius procurou por uma explicação mecânica da evidente direcionalidade dos processos térmicos - tendo, com isso, finalmente chegado ao conceito de entropia - foi Thomson quem concebeu, pela primeira vez, a segunda lei da termodinâmica como um princípio de dissipação da energia nos processos irreversíveis. Com Thomson, o conceito de energia começou a adquirir um status fundamental, assumindo o papel de conectar todos os fenômenos físicos dentro de uma teia de transformações recíprocas. Thomson iniciou o processo de substituição da prioridade do conceito de força pela prioridade do conceito de energia a partir da própria mecânica. Ele conjecturou que também os fenômenos então tradicionalmente fora da mecânica, como os elétricos e ópticos, além dos térmicos, deveriam ser subsumidos pela formulação energética da mecânica (PURRINGTON, 1997).

Durante os anos de 1852 e 1855, William Rankine desenvolveu ainda mais profundamente a filosofia mecânica baseada na primazia do conceito de energia e suas transformações. Adotando a classificação de Thomson, Rankine estabeleceu os termos "potencial" e "atual", para as atuais energias potencial e cinética, em explícita analogia com os usos filosóficos (aristotélicos) dos termos. Rankine estabeleceu então a lei fundamental da transformação da energia: "a soma da energia potencial e atual do universo é constante" (PURRINGTON, 1997).

A formulação final da lei da conservação da energia, ao longo da década de 1840, resultou da contribuição de muitos cientistas. Essa história culminou com a publicação do artigo de Hermann von Helmholtz, de 1847, no qual ele expressou as relações entre mecânica, calor, luz, eletricidade e magnetismo como diferentes manifestações da energia e seus processos de transformação. Assim, a partir de 1850, a lei de conservação da energia tinha se tornado a peça fundamental para a articulação da estrutura de uma nova física unificada, baseada em uma visão mecânica da natureza (PURRINGTON, 1997). 


\subsection{O modelo teórico.}

Para introduzir o problema teórico, podemos considerar, inicialmente, o caso simplificado de uma barra rígida de comprimento $h$, apoiada apenas sobre suas duas extremidades, cada uma concentrando uma massa $m$, em uma superfície horizontal, com atrito. O coeficiente de atrito $\mu$ entre as extremidades da barra e a superfície pode (e deve) ser medido com a ajuda de um dinamômetro. A figura 3 abaixo esquematiza a ação das forças de atrito sobre a barra girante.

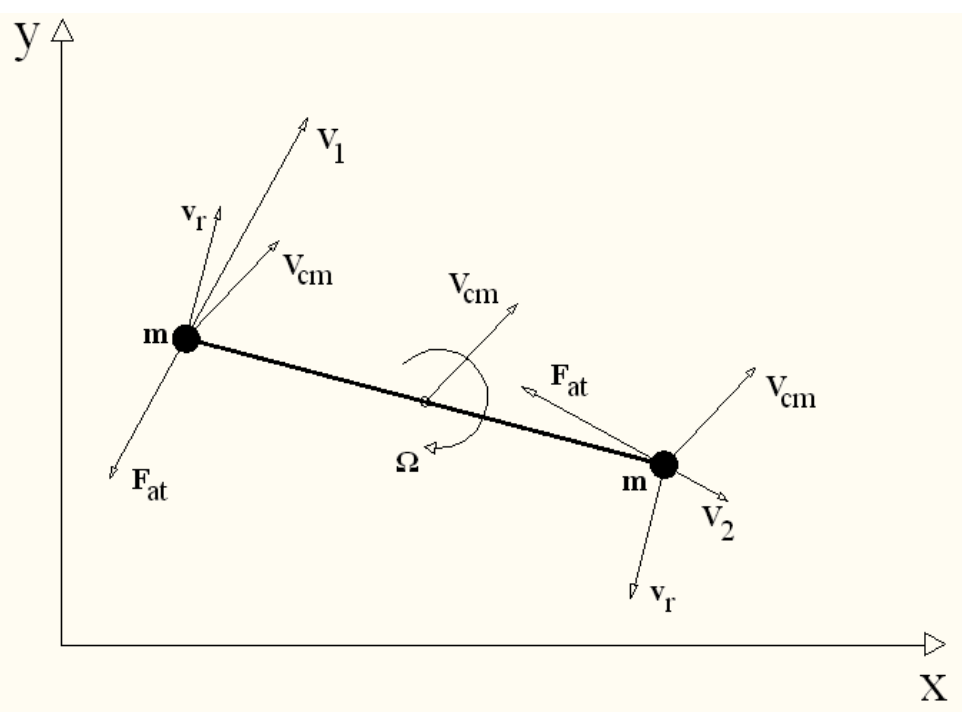

Figura 3: esquema de forças na barra girante sobre superfície com atrito.

As forças externas atuantes são funções do tempo e são, a cada instante, opostas às velocidades instantâneas $\boldsymbol{V}_{1}$ e $\boldsymbol{V}_{2}$ de cada massa (embora seu módulo seja constante).

$$
\mathbf{F}_{\mathrm{at} i}(t)=-\mu m g \frac{\mathbf{V}_{i}(t)}{\left|\mathbf{V}_{i}(t)\right|}
$$

Nessas condições, faz-se necessário lançar mão de métodos analíticos (GOLDSTEIN, POOLE, SAFKO, 2002). Em coordenadas cartesianas, as velocidades instantâneas se escrevem como: 


$$
\begin{aligned}
& \mathbf{V}_{1}(t)=\dot{x}_{1} \mathbf{i}+\dot{y}_{1} \mathbf{j} \\
& \mathbf{V}_{2}(t)=\dot{x}_{2} \mathbf{i}+\dot{y}_{2} \mathbf{j}
\end{aligned}
$$

A Lagrangeana do sistema depende apenas da energia cinética, já que não há forças derivadas de potencial. Ela será, portanto:

$$
L=T-V=\frac{m}{2}\left(\mathbf{V}_{1}^{2}+\mathbf{V}_{2}^{2}\right)=\frac{m}{2}\left(\dot{x}_{1}^{2}+\dot{y}_{1}^{2}+\dot{x}_{2}^{2}+\dot{y}_{2}^{2}\right)
$$

O número de graus de liberdade do sistema é, contudo, apenas três, já que as coordenadas estão submetidas ao vínculo:

$$
\left(x_{1}-x_{2}\right)^{2}+\left(y_{1}-y_{2}\right)^{2}=h^{2} \Rightarrow f=\left(x_{1}-x_{2}\right)^{2}+\left(y_{1}-y_{2}\right)^{2}-h^{2}=0 .
$$

A figura 4 abaixo mostra o esquema cartesiano:

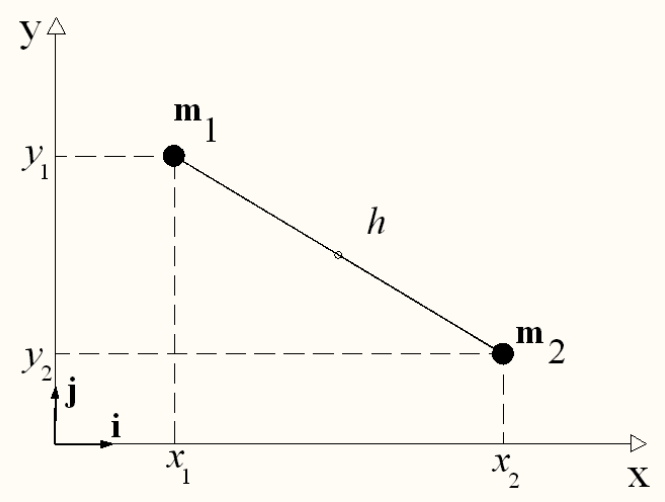

Figura 4: coordenadas cartesianas para a barra girante.

É conveniente, portanto, usar coordenadas generalizadas, de tal forma que o vínculo esteja já contemplado. As três coordenadas generalizadas convenientes para esse problema são as coordenadas cartesianas do centro de massa $X, Y$, e a inclinação da barra, $\theta$, com relação ao eixo $x$. As coordenadas cartesianas se escrevem, em função das coordenadas generalizadas, da seguinte forma:

$$
\begin{array}{ll}
x_{1}=X-\frac{h}{2} \cos \theta ; & x_{2}=X+\frac{h}{2} \cos \theta \\
y_{1}=Y+\frac{h}{2} \sin \theta ; & y_{2}=Y-\frac{h}{2} \sin \theta
\end{array}
$$


Confira a figura 5 abaixo:

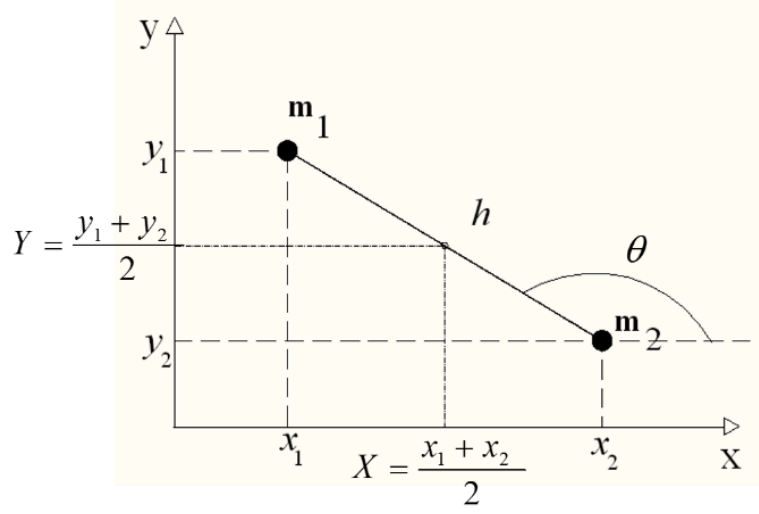

Figura 5: coordenadas generalizadas para a barra girante

Nas coordenadas generalizadas, a energia cinética do sistema se desacopla naturalmente em uma parte translacional e uma rotacional:

$$
T=m\left(\dot{X}^{2}+\dot{Y}^{2}\right)+\frac{m}{4} h^{2} \dot{\theta}^{2}
$$

onde $h$ é o comprimento da barra.

Dadas as coordenadas e velocidades generalizadas iniciais, a dinâmica é única. Evidentemente, ocorre dissipação até que a barra atinja o repouso sobre a superfície. A introdução das forças de atrito deve ser feita a partir da chamada função de dissipação de Rayleigh (GOLDSTEIN, POOLE, SAFKO, 2002):

$$
\begin{aligned}
\Phi & =\frac{1}{2} \mu m g \sqrt{4\left(\dot{X}^{2}+\dot{Y}^{2}\right)+4 h \dot{\theta}[\dot{Y} \cos \theta+\dot{X} \sin \theta]+h^{2} \dot{\theta}^{2}}+ \\
& +\frac{1}{2} \mu m g \sqrt{4\left(\dot{X}^{2}+\dot{Y}^{2}\right)-4 h \dot{\theta}[\dot{Y} \cos \theta+\dot{X} \sin \theta]+h^{2} \dot{\theta}^{2}}
\end{aligned}
$$

As equações de Lagrange, que resultam:

$$
\frac{d}{d t}\left(\frac{\partial T}{\partial \dot{X}}\right)+\frac{\partial \Phi}{\partial \dot{X}}=0, \quad \frac{d}{d t}\left(\frac{\partial T}{\partial \dot{Y}}\right)+\frac{\partial \Phi}{\partial \dot{Y}}=0, \quad \frac{d}{d t}\left(\frac{\partial T}{\partial \dot{\theta}}\right)+\frac{\partial \Phi}{\partial \dot{\theta}}=0,
$$

embora complicadas e acopladas, podem ser resolvidas numericamente, usando, por exemplo, um pacote de computação algébrica, como o MAPLE. 
É interessante constatar que a generalização para quatro massas pode representar, em uma aproximação grosseira, um carro em processo de deslizamento, conforme a figura 6 abaixo:

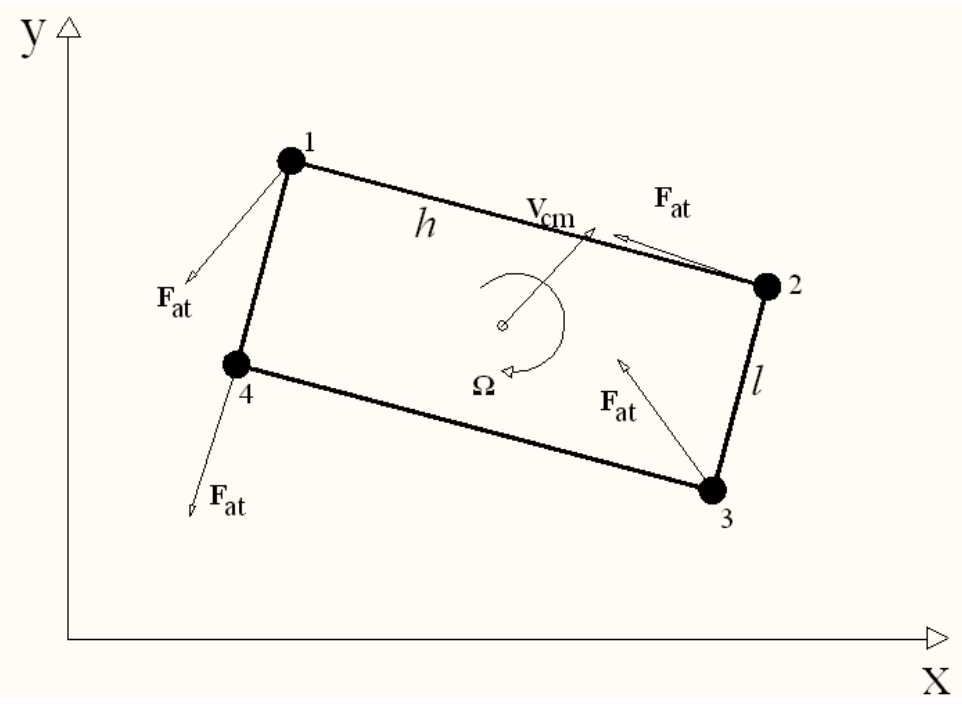

Figura 6: esquema de forças em um carro sobre superfície com atrito

O tratamento analítico dessa nova situação é o mesmo da barra girante sobre uma superfície com atrito. O número de graus de liberdade do carro girante sobre a superfície com atrito continua sendo três. As equações de Lagrange, embora ainda mais complicadas, podem ser resolvidas usando métodos numéricos. Dentre os vários interessantes fenômenos que se pode observar, a partir desse modelo, encontra-se o acoplamento dinâmico no processo de dissipação das energias translacional e rotacional.

É importante salientar que o tratamento matemático do problema não pode ser apresentado no contexto da aplicação do produto educacional e da sequência de aprendizagem, em razão de sua alta complexidade para alunos de Ensino Médio. De fato, nosso objetivo, aqui, é apenas mostrar que é perfeitamente possível calcular matematicamente as trajetórias desse sistema e, se medidas precisas das condições iniciais, em um modelo de laboratório, puderem ser feitas, é possível fazer comparações e testar a validade do modelo teórico. 


\section{Capítulo 4}

\section{O APARATO EXPERIMENTAL}

Neste capítulo, descrevemos o esquema de funcionamento do aparato experimental que permite observar o fenômeno de deslizamento de um corpo rígido sobre uma superfície com atrito, os procedimentos necessários para sua montagem e os procedimentos práticos a serem adotados para seu correto funcionamento.

\subsection{Descrição do funcionamento do aparato.}

A construção de um modelo concreto para explorar o modelo físico apresentado é relativamente simples. Como já citado na Introdução, os principais aspectos a serem observados, incluindo os fenomênicos e conceituais, estarão, primeiramente, associados aos processos de transformação entre os vários tipos mais comuns de energia mecânica. Mas, tão importante quanto isso, queremos explorar o conceito de dissipação irreversível da energia mecânica em termos de calor, através do atrito.

A estrutura conceitual que está na base do funcionamento do aparato consiste nos processos de transformação de duas energias potenciais, a saber, gravitacional e elástica- respectivamente estocadas em duas configurações independentes -, em energias cinéticas de rotação e translação, com subsequente dissipação da energia mecânica total por forças de atrito produzidas em uma superfície rugosa. A configuração estática que estoca a energia potencial gravitacional consiste em um peso incialmente mantido a uma certa altura. A configuração estática que estoca a energia potencial elástica consiste, inicialmente, em uma mola comprimida. Essas energias potenciais serão parcialmente e independentemente transferidas para um corpo rígido (carrinho), de modo a imprimir nele um movimento combinado de rotação e translação. Em seguida, o carrinho será liberado para movimentar-se livremente sobre uma superfície rugosa, que dissipará toda a sua energia. 
Para implementar esse esquema, construímos um aparato experimental capaz de executar os processos mencionados. $O$ arranjo experimental que foi efetivamente construído consiste das seguintes partes, com suas funções convenientemente descritas. Primeiramente, temos um disco que será acoplado em uma haste vertical (eixo rotor). O disco deverá ser munido de quatro pontos de apoio (carrinho), formados por pontas de pincéis (marcadores de quadro) que deverão ser tingidas com diferentes cores antes do ensaio. Dessa forma, ao deslizar sobre uma superfície plana, os pés do carrinho desenharão sua trajetória. A haste vertical (eixo rotor) possui, na sua parte superior, uma polia fixa (carretel), encaixada no eixo, na qual se enrola um fio de náilon. Inicialmente, o fio de náilon encontra-se completamente enrolado na polia. Na outra ponta do fio, encontra-se um peso, suspenso verticalmente com o auxílio de uma segunda polia, móvel. O disco e a haste adquirem um movimento de rotação conjunto que Ihe é transferido por meio do peso, à medida que ele cai sob ação da gravidade. No final de seu curso, a queda do peso terá transferido (parte de) sua energia potencial para o sistema eixo rotor e disco, numa quantidade que pode ser calculada medindo-se apenas a massa do peso e a altura total percorrida por ele.

O carrinho se solta do eixo rotor, no momento em que o peso atinge o final de seu curso, tendo desenrolado todo o fio do carretel. Depois de soltar-se da haste, o carrinho atinge a superfície rugosa com a maior parte do movimento de rotação que adquiriu com a queda do peso. Ao atingir a superfície, o carrinho encontrar-se-á girando apenas em torno de seu próprio eixo. Aproximadamente no mesmo instante em que atinge a superfície, contudo, ele deverá sofrer um impacto horizontal, de modo a receber um impulso que, combinado com o movimento de rotação, faça com que deslize sobre a superfície rugosa. Ou seja, faça com que o carrinho adquira um movimento de translação combinado a uma rotação. O dispositivo que o impulsiona é composto por uma haste metálica, acionada por uma mola comprimida (ferrolho), que transfere parte de sua energia potencial elástica para o carrinho. O carrinho movimenta-se sobre a superfície rugosa, desenhando, com os seus pés tingidos, a trajetória que será analisada, até que toda a energia adquirida a partir do conjunto (peso e ferrolho) seja completamente dissipada (de forma irreversível), perdendo velocidade até parar. 
A massa e a altura do peso, bem como a posição a partir da qual o ferrolho será disparado, podem variar e devem ser escolhidas de acordo com cada ensaio. $O$ carrinho, o eixo rotor, o ferrolho e algumas trajetórias traçadas pelo carrinho podem ser vistas na figura 7 .

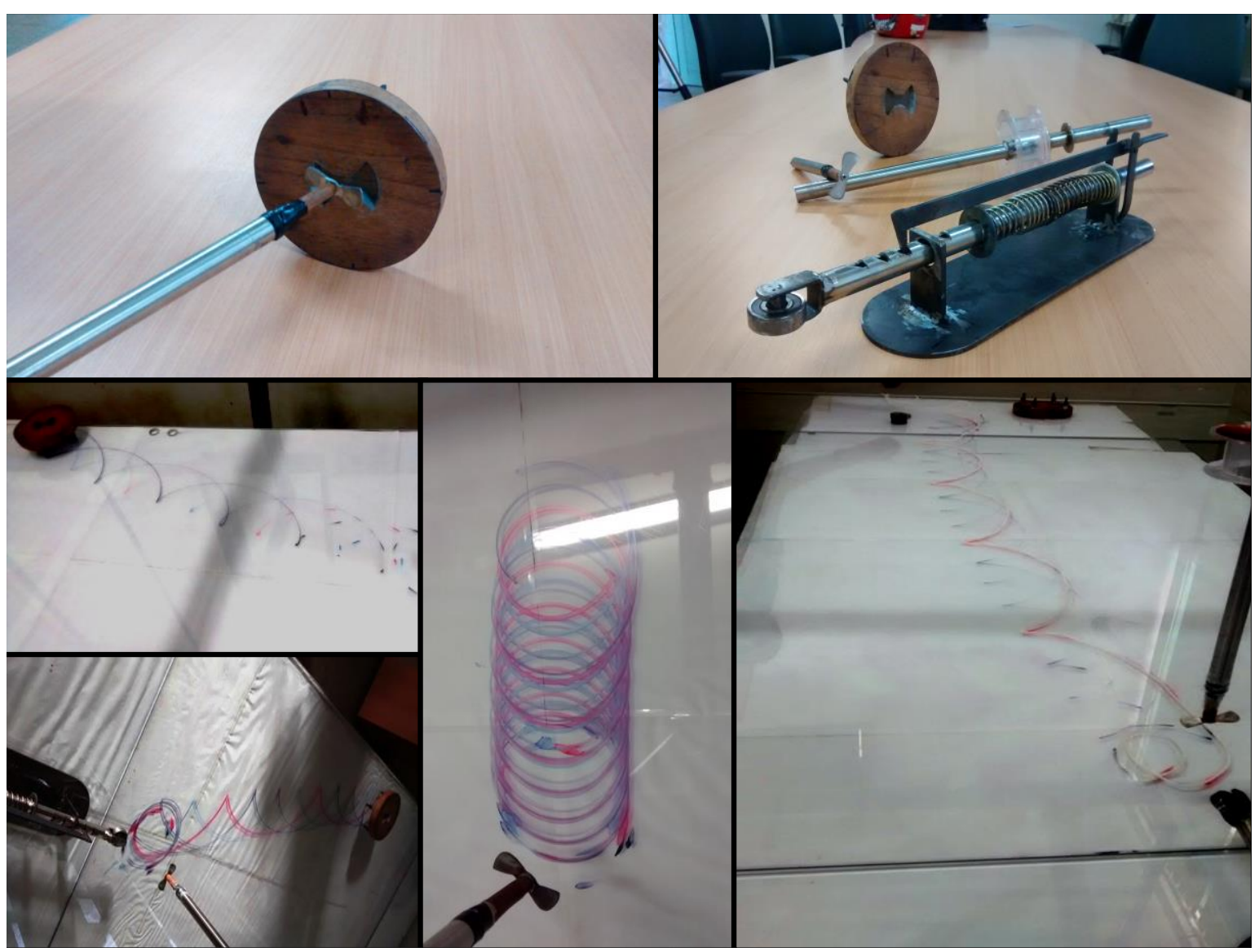

Figura 7: carrinho, eixo rotor, ferrolho e trajetórias traçadas pelo carrinho. 


\subsection{Montagem do aparato.}

Para prover uma estrutura de sustentação para o peso e o eixo rotor, deve-se montar um suporte, em forma de T, com três pés de apoio. Esse suporte deve ser colocado sobre uma mesa. Sobre a mesa, coloca-se a superfície rugosa sobre a qual o carrinho deslizará. As alturas, tanto do suporte, quanto da mesa, devem ser adaptadas para que a base do disco (corpo do carrinho) fique suficientemente próxima da superfície de deslizamento (mais ou menos $5 \mathrm{~cm}$ ), possibilitando um tempo razoável para o mais eficiente acionamento do ferrolho, no momento em que o carrinho atinge a superfície.

A superfície de deslizamento pode ser feita com qualquer tipo de material. Entretanto, recomenda-se que o material utilizado seja bem liso (sem irregularidades perceptíveis) e tenha um coeficiente de atrito não muito elevado (tal como vidro), de modo a proporcionar trajetórias mais amplas, fáceis e interessantes de serem analisadas.

$\mathrm{Na}$ barra de sustentação horizontal que compõe o suporte, deve ser feita uma perfuração, destinada a introduzir e sustentar, verticalmente, o eixo rotor. 0 eixo rotor deverá atravessar a barra de sustentação de tal forma que Ihe seja possibilitado um giro com o menor grau de travamento possível. É importante, entretanto, que não seja permitida folga excessiva, pois o eixo rotor sofrerá, necessariamente, trepidações causadas por pequenas não-uniformidades na sua distribuição de massa. Para sustentar o eixo rotor no suporte, pode-se utilizar arruelas, convenientemente fixadas, embora seja muito mais conveniente um sistema de rolamento que diminua a fricção. No eixo rotor, deve ser colocada uma polia fixa (carretel), de tal forma que ela gire juntamente com o eixo, sem deslizamento. Também na barra horizontal do suporte, coloca-se, verticalmente, duas polias, sendo que a posição, tanto do eixo, quanto das polias, dependerá do ensaio a ser realizado. Em seguida, coloca-se o fio na estrutura. Uma das extremidades do fio será atada ao eixo rotor e travada por uma ranhura previamente feita junto à borda superior do carretel. A outra extremidade será atada ao peso, de tal modo a passar pelas duas polias, que sustentarão o fio (ver figura 8). A posição inicial para cada ensaio exige, portanto, que o fio esteja completamente enrolado de modo que o peso esteja suspenso à altura desejada. 
É importante preparar uma superfície de apoio (areia ou isopor), colocada exatamente no final do curso do peso, para amortecer sua queda, evitando qualquer oscilação vertical violenta que impeça o correto funcionamento do dispositivo de desacoplamento do carrinho. Contudo, o fio não deve ficar frouxo após tocar a superfície de amortecimento, pois é justamente a sua tensão que permitirá o desacoplamento do carrinho.

O ferrolho deve ser fixado sobre a superfície horizontal do aparato - por exemplo, com o uso de ventosas -, de modo a não ser demasiadamente perturbado pelo recuo esperado após o acionamento da mola. Ele deve ser posicionado de tal modo que, ao ser destravado, sua haste metálica possa atingir o carrinho em um impacto que minimize o tempo de contato entre ambos, a fim de evitar perdas energéticas ainda mais consideráveis, por atrito (figura 8).

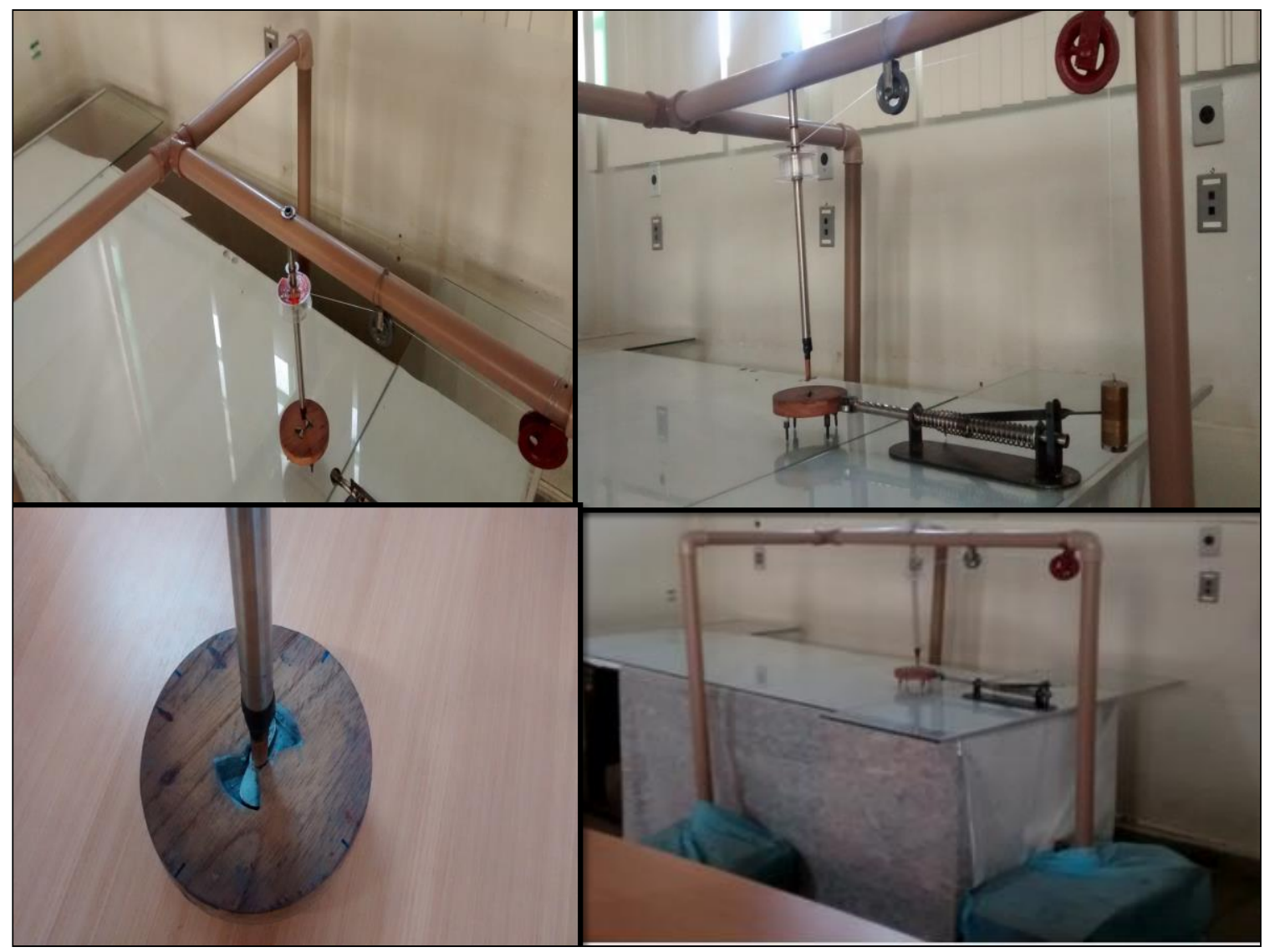

Figura 8: montagem do aparato 


\subsection{Procedimentos para execução do experimento.}

Para executar cada ensaio, deve-se escolher o peso que será utilizado (medindo sua massa com uma balança) e conectá-lo ao fio de náilon. Antes de acoplar o carrinho à extremidade do eixo rotor, é importante nivelar suas pontas de apoio (pontas de pincéis) e colocar tintas com cores diferentes nessas pontas. A massa e o raio do carrinho também devem ser medidos com o auxílio da balança e de uma régua. Em seguida, deve-se enrolar o fio de náilon no carretel até 0 peso a ser suspenso atingir a altura desejada para o ensaio. Nesse momento, deve-se segurar o eixo rotor com uma das mãos e engatar o carrinho.

A posição na qual ficará fixado o chassi do ferrolho depende da posição na qual cairá o carrinho. Antes de iniciar o ensaio, é conveniente posicionar o tripé sustentador de tal modo que a reta definida pela haste de impacto do ferrolho venha a passar pelo centro geométrico do carrinho, no ponto em que cairá, de modo a conseguir um impacto frontal, ou seja, com parâmetro de impacto zero. Uma segunda pessoa deve estar presente para realizar cada ensaio. Essa segunda pessoa será responsável por travar a mola do ferrolho de acordo com a energia potencial elástica que deseje estocar e transferir para o carrinho no seu movimento horizontal. A mola deverá ser destravada no momento em que o carrinho tocar a superfície de deslizamento.

Ao soltar o eixo rotor, o peso suspenso descerá e o conjunto (eixo rotor, carretel e carrinho) vai adquirir um movimento de rotação. No momento em que o peso atingir a superfície de amortecimento, o carrinho se desengatará do eixo rotor e atingirá a superfície de deslizamento, mantendo a maior parte do movimento de rotação que adquiriu por meio da queda do peso. Ao atingir a superfície girando, o ferrolho será destravado manualmente. Espera-se que haja suficiente sincronia para que o impacto da haste horizontal do ferrolho se dê com o menor atraso possível, evitando que o carrinho gire muito sobre o mesmo ponto. Isso não é exatamente relevante para a análise conceitual, mas trajetórias mais fáceis de serem analisadas serão descritas através desse procedimento. 


\section{Capítulo 5}

\section{ANÁLISE CONCEITUAL}

Neste capítulo, apresentamos a descrição dos principais elementos conceituais envolvidos nas duas partes cruciais em que se deve analisar um experimento: a parte correspondente aos procedimentos de medida e a parte correspondente à interpretação dos resultados. Realizaremos essas duas tarefas de forma compatível com a sequência de aprendizagem sugerida nesse trabalho e, principalmente, com a sua filosofia. Isso significa que enfatizaremos, a todo momento, o papel fundamental desempenhado pela matemática nas definições quantitativas dos conceitos e nas suas múltiplas relações de equivalência e conversibilidade - fundamentadas nos princípios gerais de conservação -, bem como na execução e interpretação dos procedimentos de medida.

\subsection{Medições necessárias para efetuar a interpretação.}

A discussão e a análise conceitual, tanto qualitativa quanto quantitativa, serão realizadas após se colocar o aparato em funcionamento e este desenhar uma trajetória sobre a superfície rugosa. Esse desenho pode ser bem variado, a depender dos valores dos parâmetros escolhidos em cada ensaio, mas todas resultam de um acoplamento entre dois movimentos, a saber: um movimento de rotação, que está diretamente relacionado com a energia potencial gravitacional estocada no arranjo, e outro de translação, que está diretamente relacionado a energia potencial elástica estocada no arranjo. Antes, contudo, são necessárias algumas operações de medida.

Para a análise quantitativa, faz-se necessário obter algumas quantidades físicas por meio de medidas diretas e obter outras indiretamente por meio de cálculos a partir das suas definições matemáticas. As medidas diretas a serem realizadas para a execução de qualquer ensaio do procedimento são apenas 0 raio e a massa do carrinho. As quantidades físicas a serem obtidas indiretamente, antes da realização de cada ensaio, são o momento de inércia do 
carrinho, o coeficiente de atrito da superfície de deslizamento, a constante elástica da mola, a energia potencial gravitacional do peso e a energia potencial elástica da mola. As medidas diretas que devem ser realizadas para cada ensaio são a altura do peso em relação à superfície de apoio, a massa do peso, a deformação da mola na posição que foi travada para o ensaio.

Por fim, uma vez realizado o ensaio, deve-se medir o comprimento da trajetória descrita pelos pés do carrinho em todo seu percurso e o comprimento da trajetória do seu centro de massa, para obter o trabalho total realizado pela força de atrito no processo de dissipação.

\subsection{Análise conceitual do fenômeno: panorama.}

Se supusermos que as forças de atrito presentes nas diversas partes do arranjo experimental são desprezíveis, o princípio de conservação da energia mecânica implica, necessariamente, que a energia potencial gravitacional estocada no peso suspenso deverá ser convertida em energia cinética de rotação do carrinho, energia cinética de rotação do eixo rotor e polias e energia cinética adquirida pelo próprio peso suspenso, no final de seu curso. Da mesma forma, se supusermos que o choque entre a haste do ferrolho e o carrinho é perfeitamente elástico, a energia potencial elástica estocada na mola deverá ser transformada em energia cinética de translação do carrinho e em energia cinética adquirida pelo pistão do ferrolho e pelo próprio ferrolho, durante o seu recuo. Assim, utilizando as expressões matemáticas adequadas, pode-se calcular a velocidade de rotação inicial, ou seja, a velocidade de rotação que o carrinho possuirá no momento em que é desacoplado. Analogamente, as expressões adequadas nos permitem calcular a velocidade de translação inicial, ou seja, a velocidade de translação que o carrinho possui no momento em que é impulsionado pelo pistão do ferrolho.

$\mathrm{Na}$ verdade, sabemos que todas as suposições acima mencionadas não são verdadeiras. De fato, em primeiro lugar, as forças de atrito presentes entre as partes móveis do arranjo não são desprezíveis. Em segundo lugar, o impacto entre o pistão do ferrolho e o carrinho não é perfeitamente elástico. Isso se 
revelou exatamente na análise dos resultados dos diversos ensaios realizados, como veremos abaixo. Esse é um ponto importantíssimo a ser destacado, pois ilustra o grau de afastamento que modelos ideais apresentam com relação ao comportamento real. Isso também ilustra o fato de que a maior parte dos avanços tecnológicos modernos envolvidos com o funcionamento de máquinas mecânicas, termodinâmicas e eletromecânicas está relacionada com o esforço de diminuir os efeitos de dissipação. Esse ponto pode e deve ser explorado didaticamente. A partir dele, os estudantes podem começar a perceber que a física (e a ciência, em geral) está envolvida com a obtenção de leis gerais que devem ser obedecidas em casos ideais cuja possibilidade de verificação está condicionada ao grau de controle que se pode ter das condições (reguladas por parâmetros externos) que não são levadas em consideração por essas leis. A sequência do fenômeno envolve o deslizamento do carrinho sobre a superfície. À medida que isso acontece, a energia cinética total fornecida ao carrinho vai sendo consumida até que ela se esgote completamente e o carrinho pare.

Em primeira aproximação, ou seja, se desprezarmos o acoplamento entre a rotação e a translação, o trabalho total pode ser dividido em duas partes independentes. A situação de desacoplamento acontece exatamente no caso da ausência de atrito. Entretanto, essa situação implica que não haverá trabalho nenhum a ser calculado. Portanto, o que queremos dizer com essa aproximação é que a situação real poderia ser imaginada como uma situação em que o carrinho ou apenas translada, sem rotação, ou apenas gira, sem translação. A situação real, portanto, seria (aproximada por) apenas uma superposição simples dos dois fenômenos, em que a energia potencial gravitacional é consumida pelo processo de rotação pura e a energia potencial elástica é consumida pelo processo de translação pura. Se essa ideia for utilizada, podemos calcular o trabalho da força de atrito aplicada no carrinho computando o número de voltas que o carrinho dá em torno de seu próprio eixo e o medindo o comprimento da trajetória do centro de massa. A soma desses dois trabalhos deve ser igual ao trabalho total realizado.

Sabemos, contudo, que o acoplamento existe. Por isso, a única forma realmente bem fundamentada fisicamente para computar 0 trabalho total 
efetuado pelas forças de atrito é medir o comprimento da trajetória real em todo o percurso, que é a média dos comprimentos das trajetórias descritas por cada um dos pés do carrinho. (A média aparece quando se soma os trabalhos efetuados sobre cada pé do carrinho, supondo que cada pé sustenta um quarto de seu peso total.) Como dissemos acima, na ausência de deformações e de processos dissipativos nas partes móveis do arranjo, o princípio de conservação da energia mecânica implica que a soma do trabalho total realizado pelas forças de atrito da superfície de deslizamento sobre o carrinho e das energias cinéticas adquiridas pelo peso suspenso, pelo eixo rotor, pelas polias e pelo ferrolho deve ser igual à energia mecânica inicial estocada na configuração do sistema. $O$ objetivo final de toda a análise é verificar em que grau essa igualdade é violada.

Nesse ponto, é interessante realizar uma consideração simplificadora muito útil. Para todos os efeitos práticos e, principalmente, didáticos, o mais importante é analisar todo o aparato como sendo uma máquina cujo objetivo é estocar energia que deverá ser o mais eficientemente possível transferida para o carrinho. Dessa forma, é irrelevante considerar, separadamente, as perdas de energia ocorridas por atrito daquelas ocorridas pela aquisição de energia cinética de todas as demais partes móveis do sistema. Aliás, essas partes móveis também terão, ao fim, suas energias cinéticas dissipadas por forças de fricção, internas ao próprio aparato. Portanto, a diferença entre a energia potencial total estocada e o trabalho executado pelo atrito da superfície deve ser igual à soma de todas as energias dissipadas no arranjo. As forças de atrito presentes entre as partes móveis do sistema fazem parte do conjunto das condições que não estão sendo consideradas - e, portanto, não estão sendo controladas - na situação teórica envolvida na validade estrita da conservação da energia mecânica.

Desse modo, é preciso salientar que o modelo teórico é um limite que, embora não possa ser alcançado, pode ser aproximado na medida em que se passe a controlar as condições que não foram consideradas. Isso se traduz, em parte, na eliminação, tanto quanto possível, dessas forças de atrito, por meio de procedimentos de otimização de funcionamento como, por exemplo, lubrificação. 
Voltando à abordagem aproximada (acima esboçada), é possível fazer uma análise alternativa do problema, de interesse didático. Para tanto, pode-se obter a diferença entre o trabalho total realizado na trajetória real e o trabalho presumidamente realizado apenas sobre o centro de massa. Essa diferença deve ser, em primeira aproximação, igual ao trabalho executado pelo atrito no movimento de rotação pura. Se isso for verdade, pode-se comparar a energia cinética de rotação com esse trabalho, estimando a quantidade de voltas que 0 carrinho poderia ter realizado e a quantidade de voltas efetivamente cumprida por ele sobre a superfície rugosa.

\subsection{Análise conceitual do fenômeno: detalhamento.}

Para realizar as medidas diretas das grandezas físicas relevantes podese utilizar apenas os seguintes instrumentos simples: régua, trena, balança e dinamômetro. Dentre as medidas a serem tomadas antes de iniciar qualquer ensaio do experimento, estão as massas do carrinho e do peso que será suspenso. Essas podem ser medidas com o uso da balança ou mesmo do dinamômetro. Da mesma forma, o raio do carrinho pode ser medido diretamente com uma régua, ou mesmo utilizando-se a expressão matemática do comprimento da circunferência: $C=2 \pi R$, o que já é uma oportunidade de demonstrar a validade de uma expressão geométrica comum. E, ainda, a altura a que peso será suspenso pode ser medida com a régua ou com a trena. Essas medidas ainda não esgotam a lista de medidas diretas a serem realizadas. Antes de cada ensaio, é conveniente já estar de posse dos valores da constante elástica da mola e do coeficiente de atrito estático entre o carrinho e a superfície de deslizamento. Essas e todas as demais grandezas físicas relevantes devem ser calculadas a partir das expressões matemáticas que as definem.

A constante elástica da mola é o coeficiente de proporcionalidade $k$ na expressão

$$
F=k x,
$$


onde $F$ representa o módulo da força a qual está submetida a mola quando comprimida de uma distância $x$. Para obtê-la, é mais conveniente usar um dinamômetro acoplado à mola do ferrolho, comprimindo-a e tomando nota de sua deformação em função da força aplicada. Esse procedimento pode ser executado em algumas posições de deformação diferentes, para aumentar a acurácia da medida, adotando-se uma média aritmética simples como valor final. A ideia por trás desse procedimento pode ser facilmente explicada para os alunos e, em exposições cujo foco é sobretudo os conceitos, e não os procedimentos, quaisquer abordagens estatísticas mais sofisticadas são desnecessárias.

O coeficiente de atrito estático relativo entre a superfície de deslizamento e os pés do carrinho é a constante de proporcionalidade $\mu$ na expressão:

$$
F_{a t}=\mu N
$$

onde $F_{\text {at }}$ representa o módulo da força de atrito que se opõe ao movimento do carrinho e $N$ representa a força normal, ou seja, o peso do carrinho. À rigor, o coeficiente de atrito que deve ser utilizado é o cinético. Entretanto, devido às maiores dificuldades envolvidas na sua obtenção, pode ser mais conveniente usar o coeficiente de atrito estático, sobretudo quando se constata que outros erros inerentes ao experimento são (possivelmente) bem maiores do que o envolvido nessa aproximação. Para calculá-lo, basta usar o dinamômetro acoplado ao carrinho, puxando-o sobre a superfície rugosa até que ele esteja prestes a iniciar o movimento. Nesse instante, toma-se nota do valor da força. É conveniente que esse procedimento seja executado várias vezes, com diferentes pesos sobre o carrinho, para aumentar a acurácia da medida, de modo que o valor a ser adotado seja a média aritmética simples dos vários resultados. Outra maneira interessante de se fazer essa medida é colocar o carrinho sobre a superfície de vidro, mas com inclinação variável. A medida das alturas com as quais o carrinho (com e sem peso) entra em movimento são um indicativo direto, proporcionando, ainda, uma boa justificativa para se revisitar os conceitos de estática e mostrar sua utilidade em outros contextos.

O momento de inércia do carrinho é dado pela expressão 


$$
I=\frac{1}{2} m R^{2},
$$

onde $m$ é a sua massa e $R$ é o seu raio. Esse é o momento de inércia de um cilindro, calculado em relação ao seu eixo de simetria. Embora haja exceções (GREF, 1998; HEWITT, 2009), o mais comum é que o conceito de momento de inércia não faça parte do conteúdo ensinado para alunos do Ensino Médio brasileiro. Entretanto, acreditamos que o esforço adicional para introduzir esse conceito é relativamente pequeno e amplamente compensado em função do seu potencial para a compreensão do fenômeno de transformação da energia potencial gravitacional em energia cinética de rotação. Pode-se, inclusive, introduzi-lo através de sua analogia formal com a massa inercial, uma vez que ambos comparecem, respectivamente, nas expressões das energias cinéticas rotacional e translacional, as quais, aliás, também apresentam expressões matemáticas análogas. O eixo rotor, ao qual o carrinho está acoplado, também possui um momento de inércia, que pode ser calculado por uma expressão análoga. Entretanto, em uma abordagem preliminar, pode-se desprezá-lo, já que é bem menor do que o momento de inércia do carrinho.

A energia potencial gravitacional estocada no peso suspenso é dada por:

$$
E_{\text {potg }}=m g h \text {, }
$$

onde $m$ é a massa do peso, $g$ é a aceleração da gravidade local e $h$ a altura de suspensão do peso.

A energia potencial elástica estocada na mola é dada por:

$$
E_{\text {potk }}=\frac{1}{2} k x^{2},
$$

A energia cinética de rotação adquirida pelo carrinho e pelo eixo rotor é dada, em função de seu momento de inércia total, pela expressão:

$$
E_{\text {cinrot }}=\frac{1}{2} I \omega^{2},
$$


onde $\omega$ é a velocidade angular adquirida pelo carrinho, aproximadamente aquela com a qual ele tocará a superfície, após desacoplar-se do eixo rotor. Evidentemente, para se obter essa energia de forma direta (e mais acurada), seria necessário efetuar a medida da velocidade angular diretamente. Essa é uma medida que requereria ou instrumentos e dispositivos mais complicados (e caros) ou o uso de aplicativos de computador. Entretanto, como nosso foco esteve menos voltado para a precisão do procedimento e mais para os conceitos que estão por trás dos processos de transformação (e dissipação) da energia, optamos por avaliar a energia cinética (e, indiretamente, a própria velocidade angular) através de sua igualdade com a energia potencial gravitacional, conforme descrito mais abaixo.

A energia cinética de translação adquirida pelo carrinho é dada pela expressão:

$$
E_{\text {cintrans }}=\frac{1}{2} m v^{2} \text {, }
$$

onde $v$ é a velocidade linear inicial adquirida pelo carrinho e $m$ é a sua massa. Evidentemente, para se obter essa energia de forma direta (e mais acurada), seria necessário efetuar a medida da velocidade linear diretamente. Da mesma forma que no caso anterior, essa é uma medida que requereria ou instrumentos e dispositivos mais complicados (e caros) ou o uso de aplicativos de computador. E, pelos motivos já expostos, optamos por avaliar a energia cinética (e, indiretamente, a própria velocidade linear) através de sua igualdade com a energia potencial elástica, conforme descrito mais abaixo.

Por fim, o trabalho total da força de atrito da superfície deve ser calculado a partir de:

$$
W=F_{a t} d,
$$

onde $d$ é a distância escalar total percorrida pelos pés do carrinho. Devemos lembrar que o carrinho possui quatro pontos de apoio sobre a superfície. São esses pontos de apoio que sofrem a ação das forças de atrito. Em um carrinho 
completamente simétrico, cada ponto de apoio sustenta exatamente um quarto do peso do carrinho. Portanto, para obter o trabalho total, é necessário computar, separadamente, o comprimento das trajetórias desenhadas pelos pés do carrinho, somando-as, ao final. Isso, evidentemente, é equivalente a calcular o trabalho usando a expressão acima com $d$ sendo obtido como a média aritmética desses comprimentos e com a força normal sendo avaliada a partir da massa total do carrinho. Para efetuar a medida do comprimento de cada trajetória, é conveniente usar um cabo flexível (por exemplo, barbante) ao longo do desenho deixado por cada pé, medindo-se, em seguida, o comprimento do cabo.

Em uma situação ideal, pode-se supor que não existem forças dissipativas interferindo no funcionamento do aparato. Desse modo, o princípio de conservação da energia mecânica implicaria que toda a energia potencial estocada na configuração do aparato seria transformada em energia cinética (do carrinho e das partes móveis do aparato alimentadas pela energia potencial gravitacional). Nessas condições, toda a energia potencial gravitacional será convertida em energia cinética de rotação, adquirida pelo carrinho, e em energia cinética das partes móveis ( $E_{\text {movPeso) }}$ :

$$
E_{\text {potg }}=E_{\text {cinrot }}+E_{\text {movPeso }} \Rightarrow m g h=\frac{1}{2} I \omega^{2}+E_{\text {movPeso }},
$$

de onde se pode fazer uma estimativa superior da velocidade de rotação do carrinho no momento que ele se solta do eixo rotor e atinge a superfície de deslizamento. Da mesma forma, a energia potencial elástica da mola seria toda convertida em energia cinética de translação, adquirida pelo carrinho logo após o impacto efetuado pelo eixo do ferrolho, acrescida da energia cinética fornecida para o próprio ferrolho ( $\left.E_{\text {movMola }}\right)$ :

$$
E_{\text {potk }}=E_{\text {cintrans }}+E_{\text {movMola }} \Rightarrow \frac{1}{2} k x^{2}=\frac{1}{2} m v^{2}+E_{\text {movMola }}
$$

de onde pode-se estimar um limite superior para a velocidade de translação inicial do carrinho. 
Se supusermos que as únicas forças que atuam sobre o carrinho são aquelas aplicadas pela superfície rugosa, então toda a energia cinética adquirida pelo carrinho deveria ser dissipada apenas pelo trabalho dessas forças de atrito. Assim, um tratamento idealizado implica que o trabalho calculado deve ser igual à soma das energias cinéticas de rotação e de translação do carrinho:

$$
W=F_{a t} d=\frac{1}{2} I \omega^{2}+\frac{1}{2} m v^{2}
$$

ou, de forma equivalente:

$$
W=F_{a t} d=m g h+\frac{1}{2} k x^{2}-E_{m o v M o l a}-E_{m o v P e s o}
$$

Sabemos, contudo, que existem forças de atrito agindo entre as partes móveis do aparato, o que significa que a situação real deve ser diferente da situação ideal. É fácil observar que tais forças de atrito são, na sua maior parte, aquelas provenientes, primeiramente, da rotação do eixo rotor contra o orifício da barra horizontal de suporte e, em segundo lugar, da fricção da haste de impacto do ferrolho contra a carcaça metálica que a sustenta. É óbvio que todas essas partes móveis que friccionam dissipam parte da energia potencial, diminuindo a eficiência do dispositivo. Tais perdas podem ser minoradas com o uso de lubrificantes e, principalmente, através de soluções mais sofisticadas, mas não podem nunca ser completamente eliminadas.

Para os fins a que se destina esse trabalho, uma estimativa das parcelas de energia entregues para os movimentos do próprio peso e do ferrolho ( $E_{\text {movPeso }}+E_{\text {movMola }}$ ) está fora de cogitação. Como o interesse está em observar o aparato como uma máquina cujo objetivo é fornecer a energia estocada para suprir o movimento do carrinho, essas parcelas podem ser consideradas como parte das perdas internas do próprio dispositivo. Isso, evidentemente, aumenta ainda mais a estimativa de sua ineficiência. Isso, contudo, não é irreal, já que perdas análogas a essas estão envolvidas em quaisquer máquinas que, para funcionar, apresentem partes móveis internas. A estimativa do percentual da energia que é perdida desses modos, ou seja, a estimativa da real eficiência do 
sistema para converter energia potencial em energia de movimento útil, é o principal objetivo a ser atingido pelo uso dessa montagem experimental. Essa estimativa pode ser dada pela razão:

$$
\eta=\frac{F_{a t} d}{m g h+\frac{1}{2} k x^{2}}<1 .
$$

Portanto, os processos dissipativos e de perdas em geral implicam que 0 trabalho total efetuado pelas forças de atrito devidas apenas à superfície deve ser substancialmente menor do que a energia potencial mecânica total estocada, inicialmente, no aparato. A diferença tem que ser o cômputo da energia que foi dissipada na forma de calor, no próprio aparato, depois que todo o sistema entra em repouso.

Se estivermos interessados apenas no processo dissipativo envolvido no deslizamento sobre a superfície, é evidente que podemos ignorar as origens das energias cinéticas do carrinho. Porém, nesse caso, temos que, forçosamente, obter suas velocidades angular e linear iniciais. Como já comentamos, isso pode ser feito com o uso de outros instrumentos e dispositivos, mas esse não foi o objetivo desse trabalho.

Por fim, uma outra análise interessante que também pode ser feita consiste em calcular, separadamente apenas os trabalhos realizados nos movimentos de translação e de rotação do carrinho. No primeiro caso, computase a distância percorrida pelo seu centro de massa. No segundo, o número de voltas que o carrinho efetuou em torno de seu próprio eixo, deduzindo, daí, a distância total percorrida apenas em rotação pura. $\mathrm{O}$ trabalho efetuado sobre 0 centro de massa pode ser comparado com a energia cinética de translação ou, equivalentemente, com a energia potencial elástica da mola. Já o trabalho efetuado sobre o movimento de rotação pura pode ser comparado com a energia cinética de rotação ou, equivalentemente, com a energia potencial gravitacional do peso. Espera-se que a diferença entre o trabalho total e o trabalho efetuado sobre o centro de massa seja igual ao trabalho efetuado sobre o movimento de rotação. Com essa análise, podemos, inclusive, estimar qual deveria ser a 
quantidade total de voltas que o carrinho efetuaria em torno de seu próprio eixo. Essas e outras análises, baseadas em medidas e cálculos baseados em expressões matemáticas, demonstram a versatilidade do aparato para a realização de múltiplas atividades didáticas. 


\section{Capítulo 6}

\section{RELATO DE APLICAÇÃO}

Neste capítulo, passamos a descrever a aplicação do produto educacional desenvolvido em sala de aula. Começamos por reapresentar nossos objetivos gerais e específicos, bem como as hipóteses de trabalho. Em seguida, apresentamos a metodologia de trabalho empregada, o local de aplicação do produto e as condições de sua aplicação. Passamos, assim, à parte principal, que é a descrição das etapas da aplicação, pari passu à sequência de aprendizagem elaborada. Na última seção do capítulo, apresentamos o trabalho de avaliação de aprendizagem, uma breve análise crítica e as conclusões a que se pôde chegar com base nela.

\subsection{Objetivos e hipóteses de trabalho.}

O aparato experimental apresentado tem potencial para incrementar a aprendizagem de uma grande quantidade de conceitos da mecânica, todos eles integrados em uma situação que apresenta bom apelo com relação às vivências já constituídas dos alunos, facilitando, desse modo, a integração dos conceitos novos, a serem aprendidos, com conceitos já organizados na estrutura cognitiva do estudante.

Os principais conceitos novos a serem desenvolvidos de maneira a adquirir significados mais claros são os seguintes: conservação, transformação e dissipação da energia, forças de atrito e trabalho executado pelas forças de atrito. Alguns deles podem ser constituídos direta e preliminarmente, através de poucas intuições, facilmente acessíveis aos alunos. A ideia é que os alunos sejam apresentados às definições "operacionais" dos conceitos mais intuitivos antes que as definições formais (matemáticas) Ihes sejam apresentadas pelo professor. Na sequência, aconselha-se que o professor apresente as definições formais dos conceitos mais elementares (constante elástica da mola, coeficiente de atrito, energias potenciais, momento de inércia) para que os alunos possam relacioná-las com todas as medidas diretas efetuadas (compressão da mola, 
forças de compressão, forças de movimentação, altura, massas, dimensões do carrinho). Os conceitos mais complexos (energias cinéticas, trabalho realizado pelo atrito) também devem ter suas definições formais (matemáticas) apresentadas, concomitantemente à apresentação dos princípios de conservação, transformação e dissipação.

A sequência de aprendizagem construída e efetivamente aplicada por nós, como parte do produto final, pode ser apenas uma entre várias possíveis. Seja qual for a sequência adotada, acreditamos que o aparato também tem potencial para abordar outros conteúdos, dentro da física teórica e experimental, que estiveram para além do nosso escopo imediato, tais como: cinemática (velocidade, aceleração, trajetória), dinâmica (leis de Newton, impulso, conservação da quantidade de movimento), termodinâmica (primeira e segunda leis), além de técnicas experimentais, como o refinamento dos processos de medida, seja do ponto de vista dos aumentos de precisão e acurácia, seja do ponto de vista da utilização de instrumentos mais sofisticados (sensores e placas de processamento). Caberá, portanto, ao professor elaborar outras sequencias didáticas de acordo com o tema que pretende desenvolver, talvez até mesmo aguardando até que o aparato experimental já esteja em funcionamento, para que ele possa perceber qual é o melhor ordenamento.

Claramente, o que se quer demonstrar - ou seja, as nossas hipóteses de trabalho - é que a utilização de uma realização fisicamente concreta de um modelo físico teórico - que pode ser bastante complicado, mas cujos conceitos envolvidos são relativamente simples - tem (i) capacidade para propiciar uma interação mais harmoniosa entre a parte qualitativa dos conceitos e suas definições matemáticas de maneira muito mais significativa (e prazerosa), aproximando cada vez mais os conceitos físicos das experiências cotidianas dos alunos e (ii) capacidade para demonstrar o caráter aproximado das leis gerais da física, quando aplicadas à situações reais.

De fato, o desenvolvimento de todo 0 trabalho (montagem $\mathrm{e}$ funcionamento do aparato) foi (e deve ser) feito de maneira a propiciar um ambiente de motivação e curiosidade que implique em investigação dos fenômenos envolvidos baseada nas chamadas "negociações" entre o saber intuitivo adquirido na convivência diária - desde as brincadeiras com carrinhos 
reais e virtuais, nos jogos de computador, até a observação de carros reais, em processos de derrapagem - e o saber aceito cientificamente. Além disso, atividades práticas tem potencial para criar um ambiente favorável à experiência afetiva entre professor e alunos, bem como entre os próprios alunos. Como já vimos, de acordo com Novak, em um evento educativo a experiência afetiva entre os envolvidos no processo, o contexto em que o evento está inserido, a matéria de ensino e a avaliação são elementos essenciais para uma aprendizagem significativa (MOREIRA,1999).

A estratégia completa utilizada para o desenvolvimento da sequência didática proposta é fundamentalmente baseada na ideia de que a manipulação direta, pelos alunos, do aparato experimental, é absolutamente necessária para suprir as condições acima mencionadas. Entre outras coisas, espera-se que ela dê oportunidade aos estudantes de desenvolver algumas habilidades de resoluções de problemas que avancem para além dos procedimentos puramente mecânicos, contribuindo não apenas para que realizem as mudanças conceituais envolvidas na aprendizagem verdadeiramente significativa, como tenham uma oportunidade para que eles comecem a adquirir espírito cientifico (TAMIR, 1991). Por aquisição de espírito científico, em um nível básico de educação, queremos dizer alcançar não apenas uma repetição de esquemas pré-concebidos, mas, sobretudo, uma compreensão crítica da estrutura dos conceitos físicos utilizados.

Evidentemente, espera-se que $\mathrm{o}$ aparato propriamente dito $\mathrm{e}$ as estratégias utilizadas para desenvolver o trabalho supram as condições que os tornem potencialmente significativos. Além disso, a investigação, a análise conceitual e a discussão realizadas pelos alunos podem permitir que esse evento educativo possa ser utilizado como um verdadeiro laboratório que ofereça oportunidades únicas de identificar e diagnosticar concepções alternativas dos alunos (DRIVER,1988). Acreditamos que a utilização conjunta do aparato e da sequência didática elaborada para utilizá-lo permita abordar os diversos conteúdos relacionados com o conceito de energia - normalmente ensinados no primeiro ano do Ensino Médio - "negociando" os conceitos prévios cotidianos sobre energia que, em geral, não estão de acordo com os conceitos científicos (SOLBES, TARIN, 2004). De maneira mais dinâmica, em situação de 
investigação real, podemos aspirar a desenvolver as quatro ideias fundamentais associadas ao conceito de energia: transformação, conservação, transferência e dissipação. Frequentemente, professores deixam de desenvolvê-los ou fazem apenas uma abordagem superficial e isso pode estar também diretamente ligado à maneira com que os livros didáticos vêm abordando tais características básicas (SOLBES, TARIN, 2004).

Portanto, em se levando em consideração todos esses contextos e, a título de resumo, é possível indicar os seguintes objetivos gerais que procuramos atingir através desse trabalho: (i) idealizar e construir um aparato experimental que possa ser manipulado diretamente pelos alunos; (ii) estudar o impacto que o uso desse aparato pode ter na melhoria da aprendizagem significativa de conceitos básicos de mecânica e ensejar experiências afetivas positivas, tornando as aulas de física mais interativas e voltadas para o cotidiano dos alunos; (iii) investigar, como hipótese de trabalho, o real efeito positivo que aulas experimentais podem causar no sentido de integrar, de forma mais harmoniosa, os conceitos físicos e suas definições matemáticas formais.

Quanto aos objetivos específicos, o produto educacional desenvolvido procurou fazer com que os estudantes fossem capazes de: (i) praticar a identificação, a medição e a conceitualização dos conceitos físicos de energia, trabalho e força, com vistas a alcançar suas definições formais; (ii) relacionar as grandezas físicas entre si, constituindo tais relações em termos de leis e princípios gerais; (iii) analisar, resolver e interpretar problemas envolvendo transformação, conservação e dissipação de energia.

\subsection{Metodologia e plano de trabalho.}

Para atingir os objetivos propostos, construímos o aparato experimental que se constituiu de um carrinho (corpo rígido) em processo de deslizamento sobre uma superfície com atrito, para ser manipulado diretamente pelos alunos, ou em sala de aula, ou em um laboratório.

Em seguida, elaboramos e escrevemos um material didático, na figura de uma sequência de aprendizagem, no qual procuramos fazer com que os conceitos físicos emergissem em íntima conexão com suas definições 
matemáticas, sobretudo no que se refere ao contexto da medida, tanto direta, quanto indireta, das grandezas físicas.

Para a aplicação, utilizamos uma estratégia baseada na participação ativa dos alunos, em um processo de interação progressiva com o aparato experimental. Primeiramente, os alunos foram apresentados ao aparato já montado e posto para funcionar, tendo sido destacados os materiais e métodos utilizados para construí-lo. Mais do que isso, foi enfatizado que o movimento do carrinho sobre a superfície era um modelo para a compreensão de um fenômeno com o qual eles possuem familiaridade: a derrapagem de um carro fora de controle. Uma investigação prévia do grau de compreensão alcançado nesse primeiro contato foi realizada por meio da construção de mapas conceituais. Os erros demonstrados pelos estudantes puderam, desse modo, orientar o trabalho a ser executado dali por diante. Em seguida, passou-se a uma exposição teórica dos conceitos envolvidos. O objetivo era mostrar que um conjunto suficientemente bem ordenado de conceitos, leis e princípios era capaz de suprir as condições para o entendimento mais detalhado daqueles fenômenos. $O$ exemplo dos carros em processo de derrapagem assumiu, aqui, um nítido papel de organizador prévio.

Em uma segunda apresentação do aparato, os alunos foram estimulados a fazer um primeiro contato ativo com o experimento de modo que ele pudesse interagir com suas vivências concretas de situações análogas. Ao manipular o experimento, os alunos foram instigados a desenvolver um entendimento intuitivo dos fenômenos apresentados e a discutir sobre o assunto com os colegas, tendo o professor como mediador. Os conceitos físicos que seriam estudados foram, então, tratados qualitativamente. Esse segundo contato, portanto, teve o duplo papel de servir como motivador para a aprendizagem, em virtude do evidente potencial lúdico da experiência, e de despertar a curiosidade no sentido de tentar entender melhor os detalhes envolvidos.

O objetivo subsequente consistiu em retornar ao experimento, dessa vez, para ultrapassar o nível meramente intuitivo e lúdico. A experiência foi executada em, essencialmente, três etapas. A primeira envolveu medidas diretas para aquisição dos dados necessários para constituir as grandezas físicas iniciais (energias potenciais e cinéticas) e dos parâmetros básicos necessários para 
analisar o processo (coeficiente de atrito e constante elástica da mola). A segunda etapa consistiu no disparo do carrinho para que ele deslizasse sobre a superfície. A terceira, na observação das trajetórias. Tabelas e gráficos foram montados, para auxiliar a coleta e o tratamento.

O passo seguinte foi realizar a análise conceitual do experimento, uma tarefa fundamental para estruturar a compreensão quantitativa dos princípios físicos envolvidos. Por fim, utilizamos novamente os mapas conceituais para avaliar o grau de aquisição de conhecimento.

\subsection{Local e condições da aplicação.}

A aplicação do produto educacional foi feita no Instituto Federal do Norte de Minas Gerais (IFNMG-Salinas, figura 9). O IFNMG-Salinas fica na Fazenda Varginha, km 02, Rodovia MG-404, zona rural do município de Salinas, que possui uma área de 1.891,33 km², com população de 37.234 habitantes (figura 10). Salinas, localiza-se no Norte de Minas, Vale do Jequitinhonha, e é conhecida como a "Capital Mundial da Cachaça" pela tradição que tem na produção de cachaças de excelente qualidade, reconhecidas internacionalmente (ARQUIVO DO IFNMG).

O campus IFNMG-Salinas possui cursos superiores e cursos técnicos integrados com ensino médio. Dentre esses, o curso técnico de informática. 0 trabalho foi desenvolvido em uma turma do $1^{\circ}$ ano desse curso, com trinta e dois alunos. O professor de física da turma e o técnico de laboratório de física da instituição colaboram ativamente para o sucesso do trabalho. Os alunos foram divididos em três grupos, visando facilitar a sua participação mais ativa. $O$ desenvolvimento do trabalho requereu, do professor, um total de vinte e três aulas de cinquenta minutos. Entretanto, como a turma foi dividida em grupos, o total de aulas requeridas foi de apenas onze, contadas por aluno (vide seção $6.4)$.

A maior parte do trabalho foi realizada extra turno, ou seja, fora do horário de aula, e aos sábados. Ainda assim, a maioria dos discentes participou ativamente do projeto. A turma se mostrou muito envolvida na atividade, entusiasmada e interessada em resolver cada atividade proposta e, com certa 
frequência, solicitava a ajuda do professor. Houve várias discussões entre os alunos dentro do grupo e entre um grupo e outro. Os alunos que, por algum motivo, faltaram em alguma etapa do trabalho, tiveram o cuidado de pedir para fazer em outro momento, demonstrando interesse e responsabilidade com 0 trabalho.

Adicionalmente, apresentamos esse produto em um minicurso para 0 curso de licenciatura em física, conforme relatado no Apêndice B. 


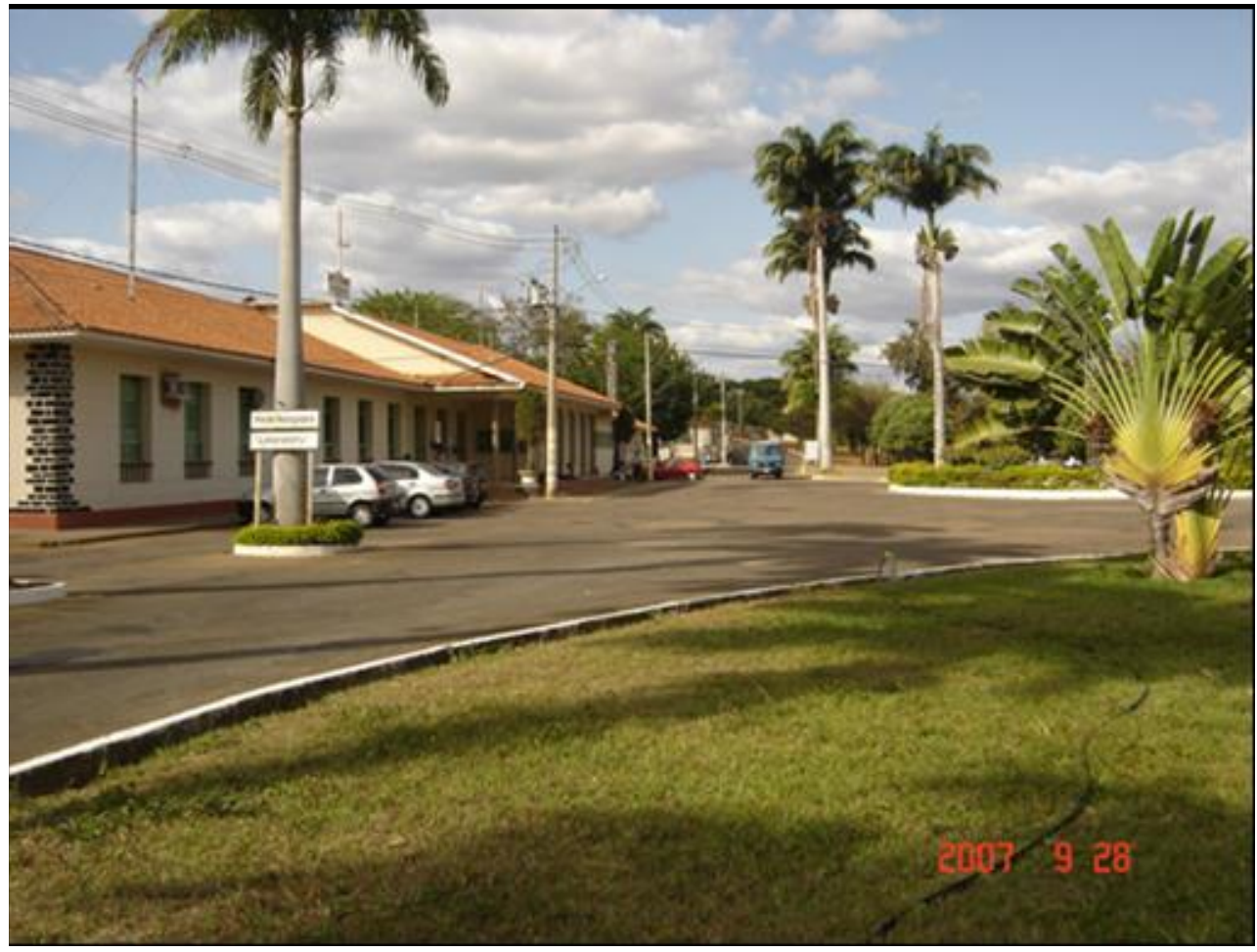

Figura 9: Instituto de Salinas, Fonte: Arquivo do IFNMG.

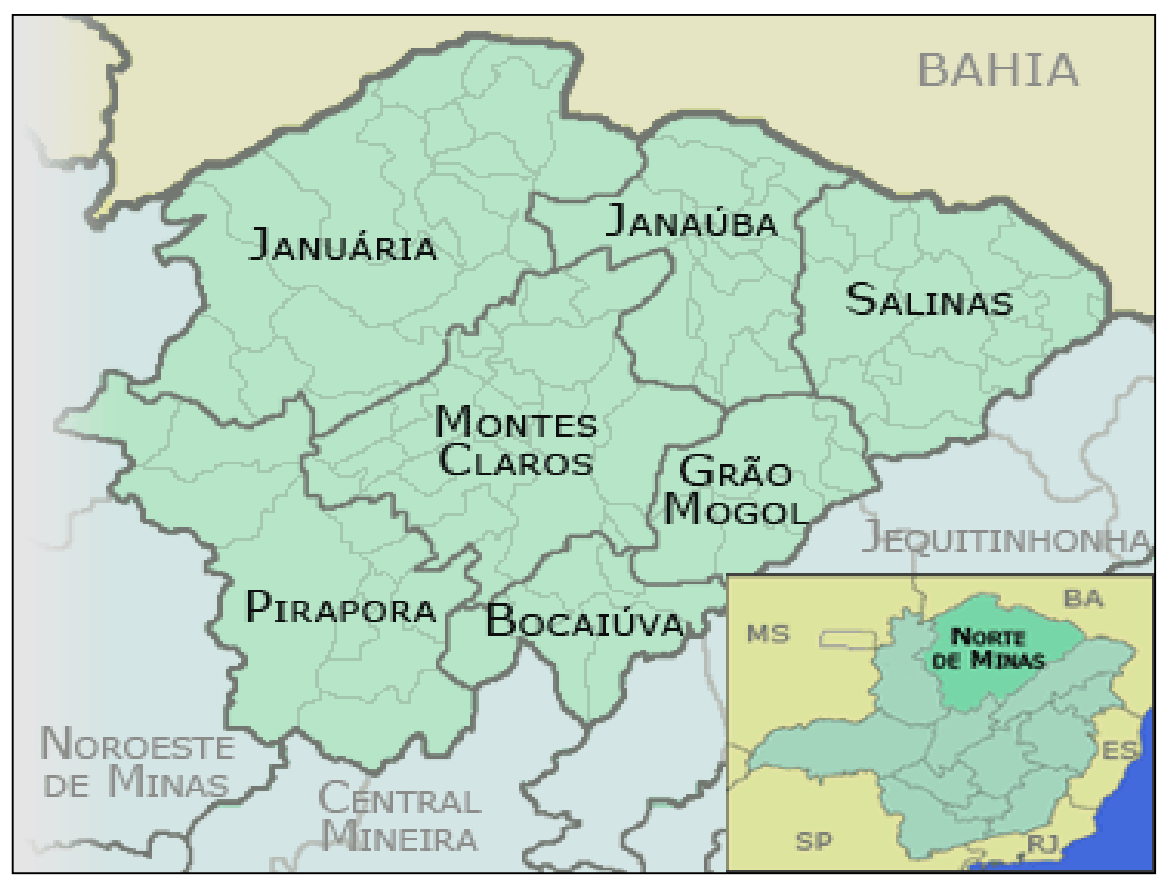

Figura 10: mapa do norte de Minas Gerais. 


\subsection{Etapas da aplicação e sequência de aprendizagem.}

O trabalho foi desenvolvido em seis etapas, a seguir resumidas:

1a etapa: apresentação do aparato e aplicação do pré-teste (duas aulas, para a turma toda).

2⿳亠口冋 etapa: exposição teórica (uma aula, para a turma toda).

3a etapa: funcionamento e manuseio do aparato, realização dos ensaios e discussões (três aulas, uma para cada grupo).

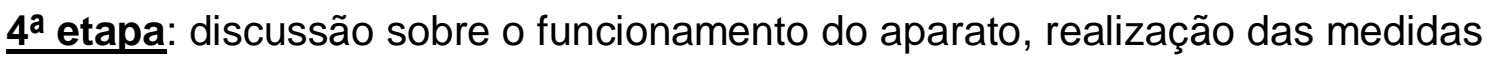
dos parâmetros do experimento, construção de tabelas, demonstrações dos recursos utilizados para realizar as medidas (nove aulas, três para cada grupo). 5a etapa: análise conceitual (seis aulas, duas para cada grupo).

6a etapa - aplicação do pós-teste e questionário (duas aulas, para a turma toda).

Todas as etapas requereram um total de onze aulas, por aluno. Passamos, agora, a detalhar as atividades de cada etapa.

\section{Primeira etapa}

O aparato experimental já estava montado no laboratório didático da escola. Os alunos foram conduzidos até o local para visualizarem o aparato, onde fiz uma explicação para que eles pudessem entender como ele foi montado, tivessem uma demonstração de seu funcionamento e Ihes fossem apresentados os conceitos que seriam abordados com o seu uso. Utilizando-me do exemplo de um carro em processo de derrapagem como um organizador prévio, os conceitos de energia potencial gravitacional, energia potencial elástica, energia cinética de rotação, energia cinética de translação, transformações de energia, conservação de energia, forças de atrito, trabalho e dissipação foram apresentados de forma puramente qualitativa, associados, intuitivamente, aos fenômenos que eles estavam observando.

De volta à sala de aula, pedi para que os alunos construíssem um mapa conceitual sobre os conceitos que foram expostos e que seriam abordados no trabalho. Para que isso fosse possível, fiz uma breve explicação de como construir um mapa conceitual. Alguns alunos relataram já saber como construir 
um mapa conceitual, pois já haviam realizado outros trabalhos utilizando este tipo de recurso, na disciplina de história. Contudo, optei por construir, no quadro, um sobre cinemática, tema escolhido pelos alunos como exemplo. Em seguida, eles receberam um guia impresso, contendo conceitos, expressões matemáticas e exemplos envolvendo o tema e que deveriam ser abordados no mapa conceitual, visando auxiliá-los na execução da tarefa (guia 1).

O objetivo desse procedimento foi investigar os conhecimentos prévios dos alunos sobre os tópicos que seriam estudados durante todo 0 desenvolvimento do trabalho, sobretudo porque foi constatado que a turma se apresentava heterogênea. Segundo Ausubel, o professor deve tentar descobrir o que o aluno já sabe a respeito de determinado assunto e tentar elaborar estratégias de ensino adequadas a isso. Para ocorrer uma aprendizagem significativa, os conceitos e proposições específicos já existentes na estrutura cognitiva do estudante devem servir de âncora para organizar o novo conhecimento, de forma hierarquizada (MOREIRA,1999). Além disso, os mapas conceituais, após serem corrigidos, podem também servir como organizadores prévios.

Ao analisar os mapas conceituais feitos pelos alunos, foi possível constatar que eles tinham, em geral, poucas informações prévias sobre o tema e que muitos não conseguiram relacionar os conceitos com as suas expressões matemáticas ou mesmo com os exemplos. Foi possível detectar também que muitos deles simplesmente utilizaram uma sequência aleatória, sem demonstrar coerência nas organizações realizadas. No momento em que estavam fazendo os mapas, alguns alunos (cerca de quatro) disseram que, apesar de já terem estudado esses conteúdos, não lembravam mais o que eles significavam e nem as relações deles com as expressões matemáticas, ou seja, estudaram, mas já haviam esquecido todo o conteúdo, pelo menos aquele relacionado com o guia 1. Alguns mapas conceituais construídos pelos alunos e utilizados como ferramenta para nortear as discussões são mostrados nas figuras 11, 12 e 13. 
Utilize esta folha para auxiliá-los na construção do mapa conceitual.

- Energia associada à posição vertical (altura).

- Conservação de energia.

- Quando comprimimos ou esticamos uma mola ou elástico.

- Depende da natureza e da rugosidade da superfície (coeficiente de atrito).

- Num sistema isolado a energia total não pode variar.

- Energia que está relacionada à posição do objeto em relação a um ponto de referência.

- Momento de inércia.

- Uma criança parte do repouso no alto de um toboágua.

- Energia cinética de translação.

- Não depende da trajetória.

- Energia potencial gravitacional.

- Energia que está relacionada ao estado de movimento do objeto.

- Força elástica.

- Uma criança correndo de bicicleta.

- Energia potencial elástica.

- Energia perdida devido ao atrito.

- Energia cinética de rotação.

- Energia mecânica.

Algumas equações matemáticas que podem ser colocadas no mapa:
$W=F_{\text {at. }} \cdot d$
$E=\frac{1}{2} \cdot I \cdot w^{2}$
$F_{a t}=\mu . N$
$I=\frac{1}{2} \cdot m \cdot R^{2}$
$E=m \cdot g \cdot h$
$F=k \cdot x$
$E=\frac{1}{2} k \cdot x^{2}$
$E=\frac{1}{2} \cdot m \cdot v^{2}$

\section{Guia 1}




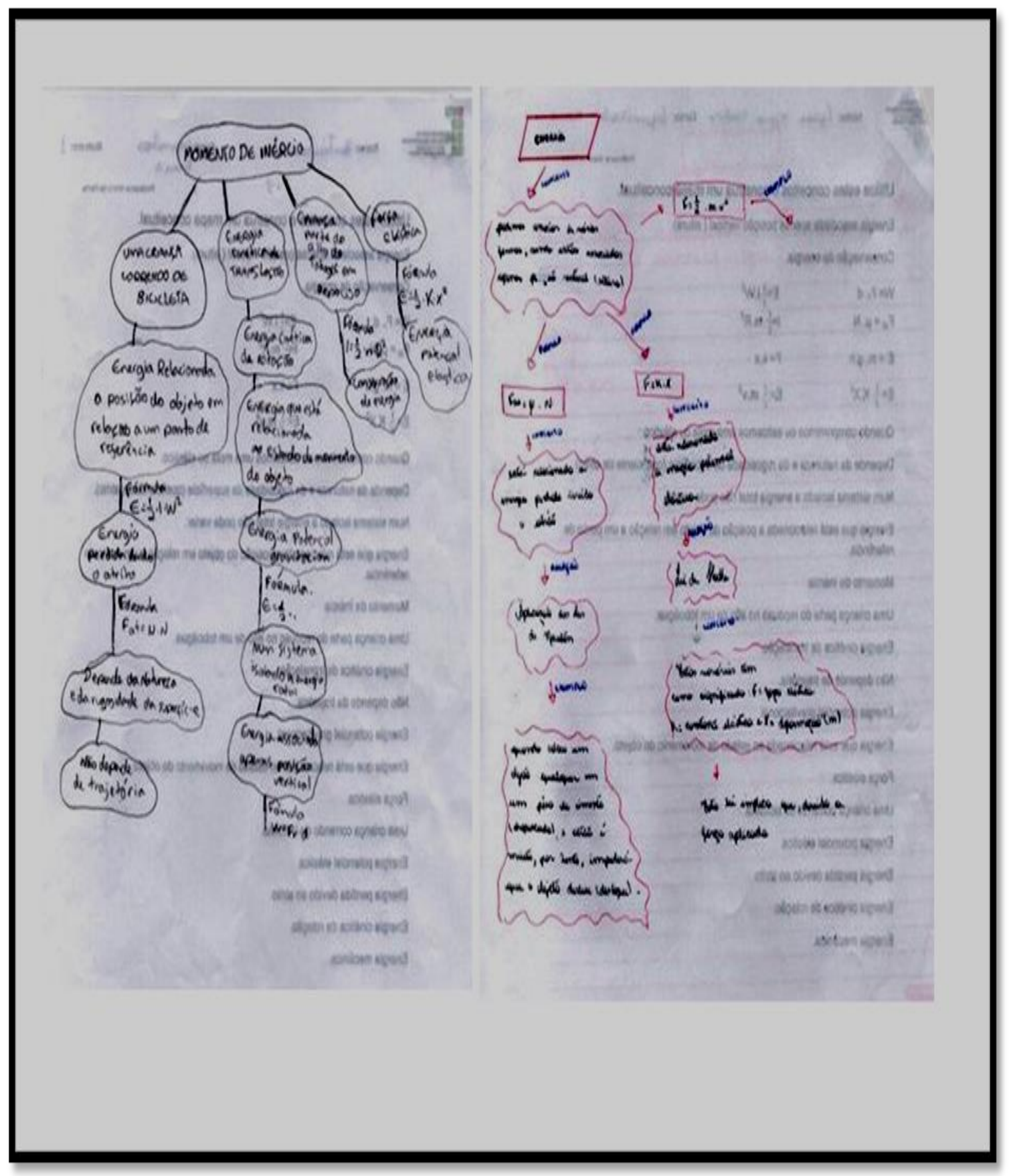

Figura 11: mapas conceituais feitos pelos alunos (pré-teste) 

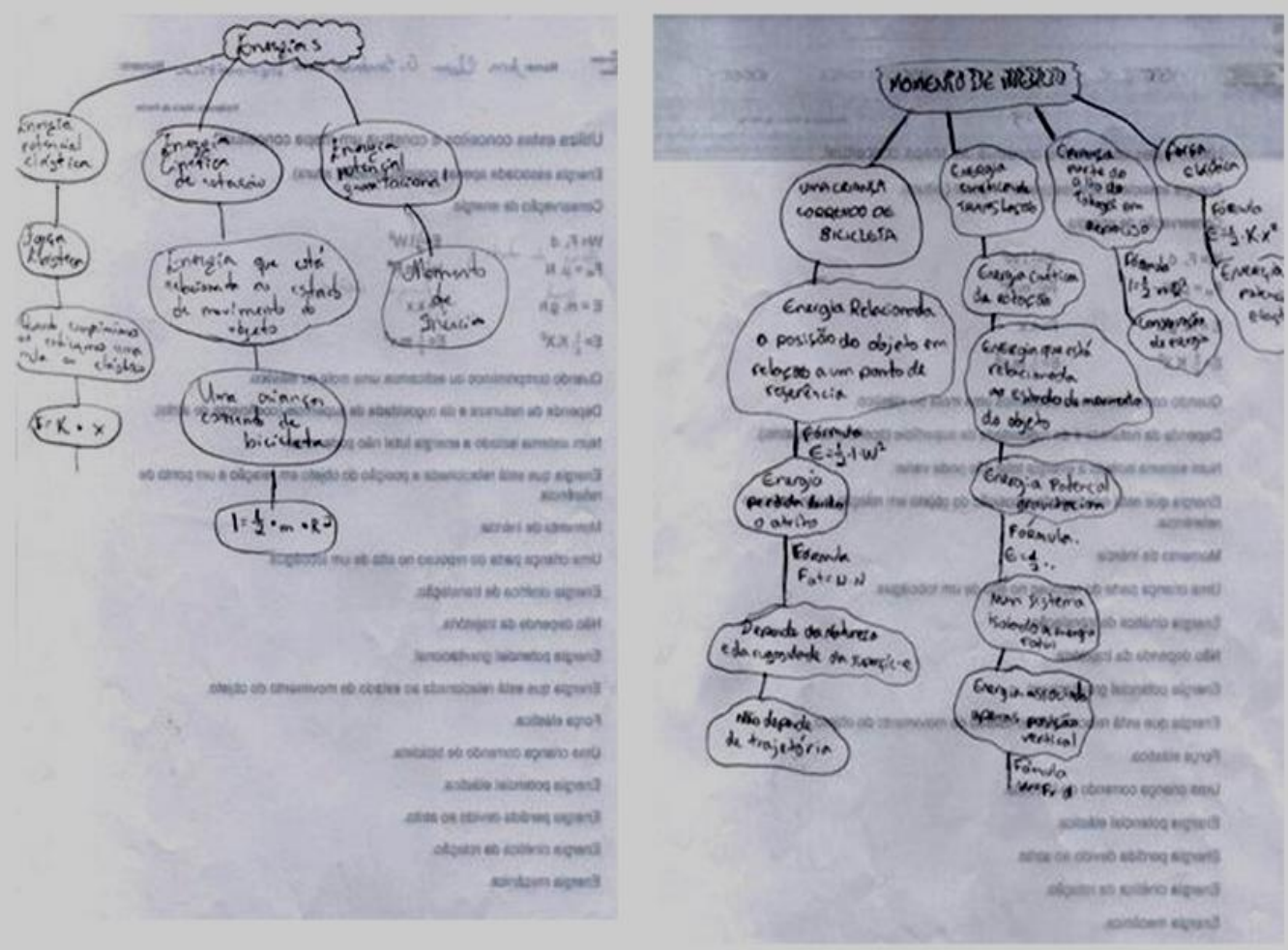

Figura 12: mapas conceituais feitos pelos alunos (pré-teste) 

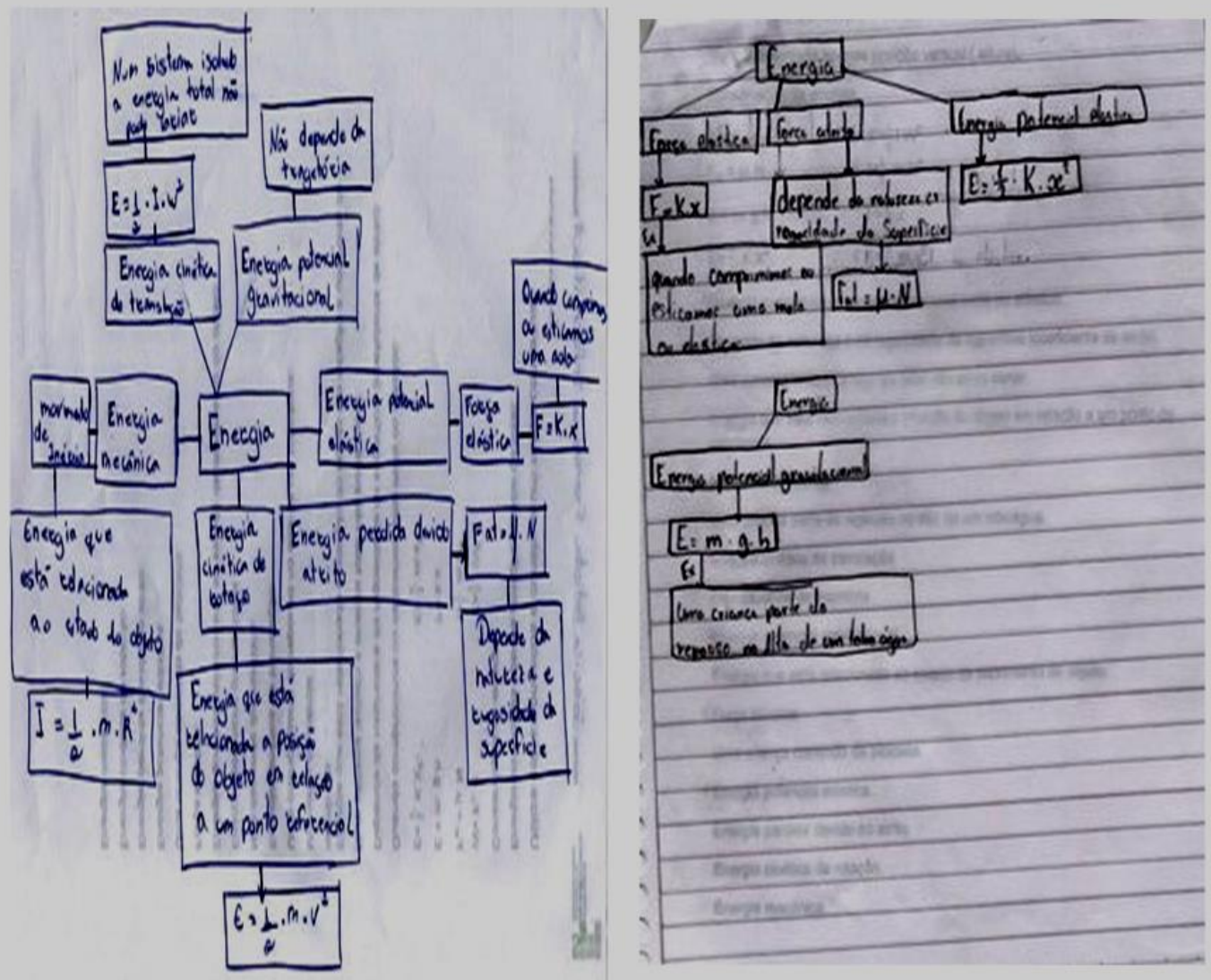

Figura 13: mapas conceituais feitos pelos alunos (pré-teste) 


\section{Segunda etapa}

Após analisar os mapas feitos pelos alunos, ficou evidente que seria necessária uma exposição teórica a respeito dos conceitos físicos a serem abordados, antes de iniciar o trabalho com o arranjo experimental. Já ao final da primeira etapa, os alunos foram convidados a pesquisar, em casa, sobre os conteúdos discutidos. A segunda etapa iniciou-se com uma aula expositiva na qual foram abordados os conceitos e temas principais: energia potencial gravitacional, energia potencial elástica, energia cinética de rotação, energia cinética de translação, dissipação, conservação da energia, transformações de energia e trabalho. Nessa etapa, os conceitos que haviam sido abordados de forma qualitativa começaram a ganhar estrutura quantitativa, por meio de suas definições matemáticas, às quais haviam sido previamente expostos, durante a confecção dos mapas conceituais (vide guia 1).

Em seguida, passou-se a uma breve discussão livre sobre os temas, para que os alunos expusessem os conteúdos de suas pesquisas, a fim de verificar a relação que eles haviam feito entre os conceitos apresentados qualitativamente na primeira etapa e suas vivências particulares.

Por fim, a turma foi dividida em três grupos para que pudesse iniciar o trabalho com a parte experimental.

\section{$\underline{\text { Terceira etapa }}$}

Essa etapa foi aquela na qual, pela primeira vez, os alunos puderam manusear o aparato. Vários ensaios foram efetivamente realizados, com participação ativa e exclusiva dos alunos. Ela foi cumprida com cada um dos três grupos, separadamente, de modo que três aulas foram utilizadas, no total.

Cada grupo trabalhou escolhendo vários parâmetros de altura, peso e compressão da mola, tendo obtido, dessa forma, muitas trajetórias diferentes que puderam ser analisadas qualitativamente. O objetivo era que os alunos já começassem a realizar conexões entre duas intuições: a intuição qualitativa, baseada na observação pura dos fenômenos, e a intuição quantitativa, baseada nos valores estimados das grandezas físicas envolvidas nos parâmetros escolhidos por eles. Ou seja, embora não tenham realizado, de fato, nenhuma medida dos parâmetros relevantes, os alunos puderam ganhar uma intuição dos 
efeitos produzidos em função de suas escolhas (p. ex.: uma maior altura do peso suspenso produzia uma maior velocidade de rotação do carrinho, etc.).

Além de proporcionar a possibilidade de fazer as primeiras conexões diretas entre as partes qualitativa e quantitativa dos conceitos e criar familiaridade com os fenômenos e com o arranjo experimental, essa etapa foi pensada separadamente das demais também visando incentivar a curiosidade dos alunos sobre o futuro andamento dos trabalhos e propiciar um ambiente que favorecesse as relações afetivas, através de tarefas cooperativas, contribuindo, assim, para que eles se sentissem mais motivados a aprender. Em razão dessas necessidades, as medidas propriamente ditas, tanto as diretas quanto as medidas do coeficiente de atrito e da constante elástica da mola, foram deixadas para a etapa seguinte.

Em suma, no laboratório, os alunos manusearam o aparato: escolheram o peso a ser suspenso, colocaram tinta nos pés do carrinho, enrolaram o fio de suspensão do peso no carretel afixado no eixo rotor, acoplaram o carrinho no eixo rotor, travaram e posicionaram o ferrolho e, ao soltar o peso suspenso e observar a queda do carrinho na superfície, dispararam o ferrolho. Esses procedimentos foram feitos em duplas até que fosse possível conseguir uma trajetória que pudesse ser analisada com facilidade (figura 14), tarefa da etapa seguinte. 


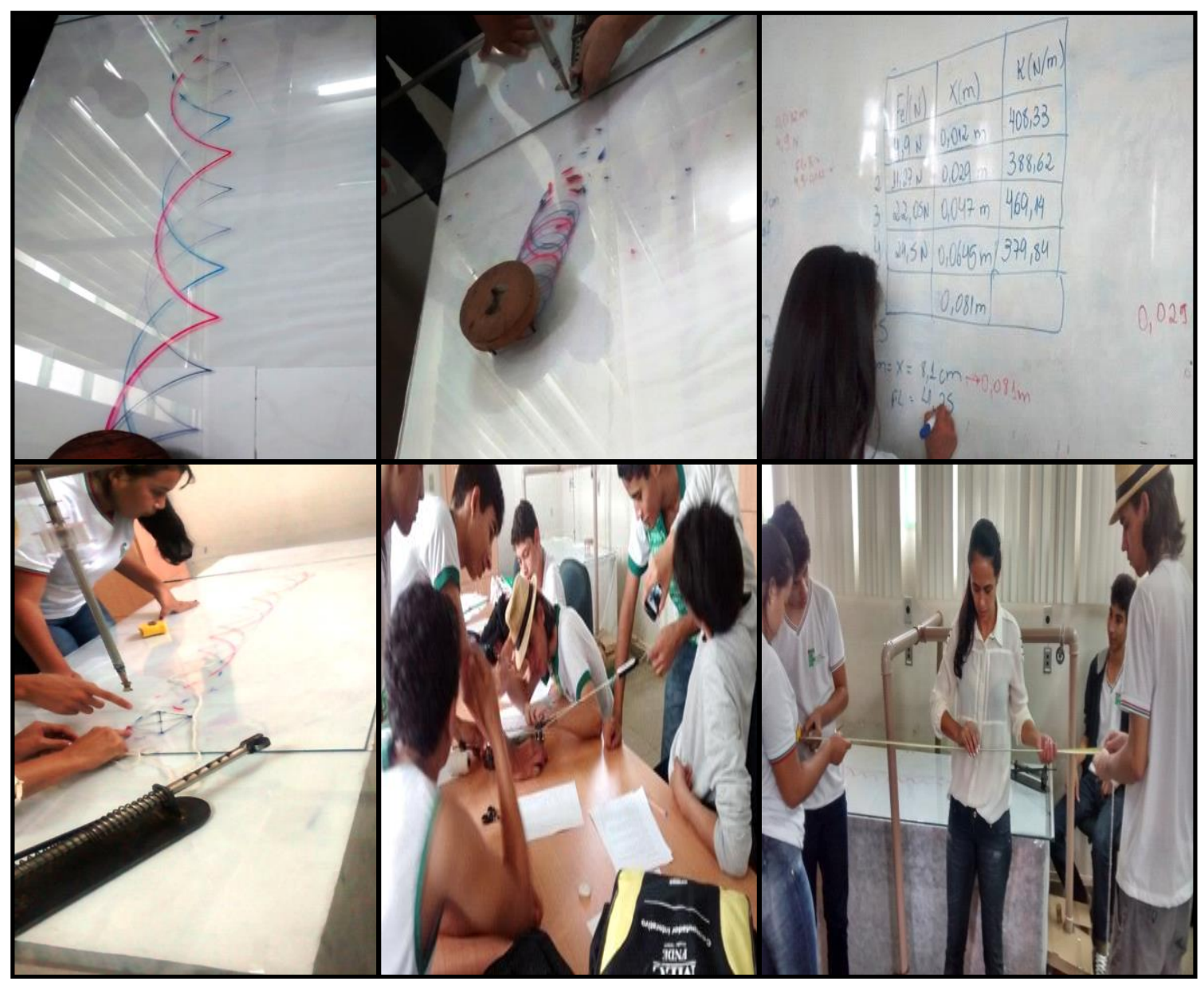

Figura 14: Alunos fazendo as medidas e construindo tabelas 


\section{Quarta etapa}

Iniciamos essa etapa fazendo uma discussão sobre todas as transformações de energia observadas com o funcionamento do aparato, do trabalho realizado pelas forças de atrito ao longo da trajetória marcada na superfície horizontal (vidro) e das demais possíveis fontes de dissipação de energia ocorridas durante todo o processo.

Em seguida, dividi cada grupo em três subgrupos, de três ou quatro integrantes, e forneci uma sequência de procedimentos a serem realizados (guia 2). Essa sequência de procedimentos foi dividida em duas partes intituladas "préensaio" - destinada à execução das medidas necessárias para a obtenção do coeficiente de atrito estático (relativo entre a superfície e os pés do carrinho), da constante elástica da mola e das alturas e massas envolvidas - e "ensaio" destinada à execução do disparo, desenho da trajetória sobre a superfície e medidas das trajetórias.

Cada um dos três subgrupos incumbiu-se de uma das três tarefas da atividade "pré-ensaio". Já as tarefas constantes da atividade "ensaio" foram realizadas por todos os elementos de cada grupo. Após o término das atividades, os grupos foram instruídos a registrar na lousa suas medidas e apresentar para os colegas os procedimentos realizados (figura 15). 


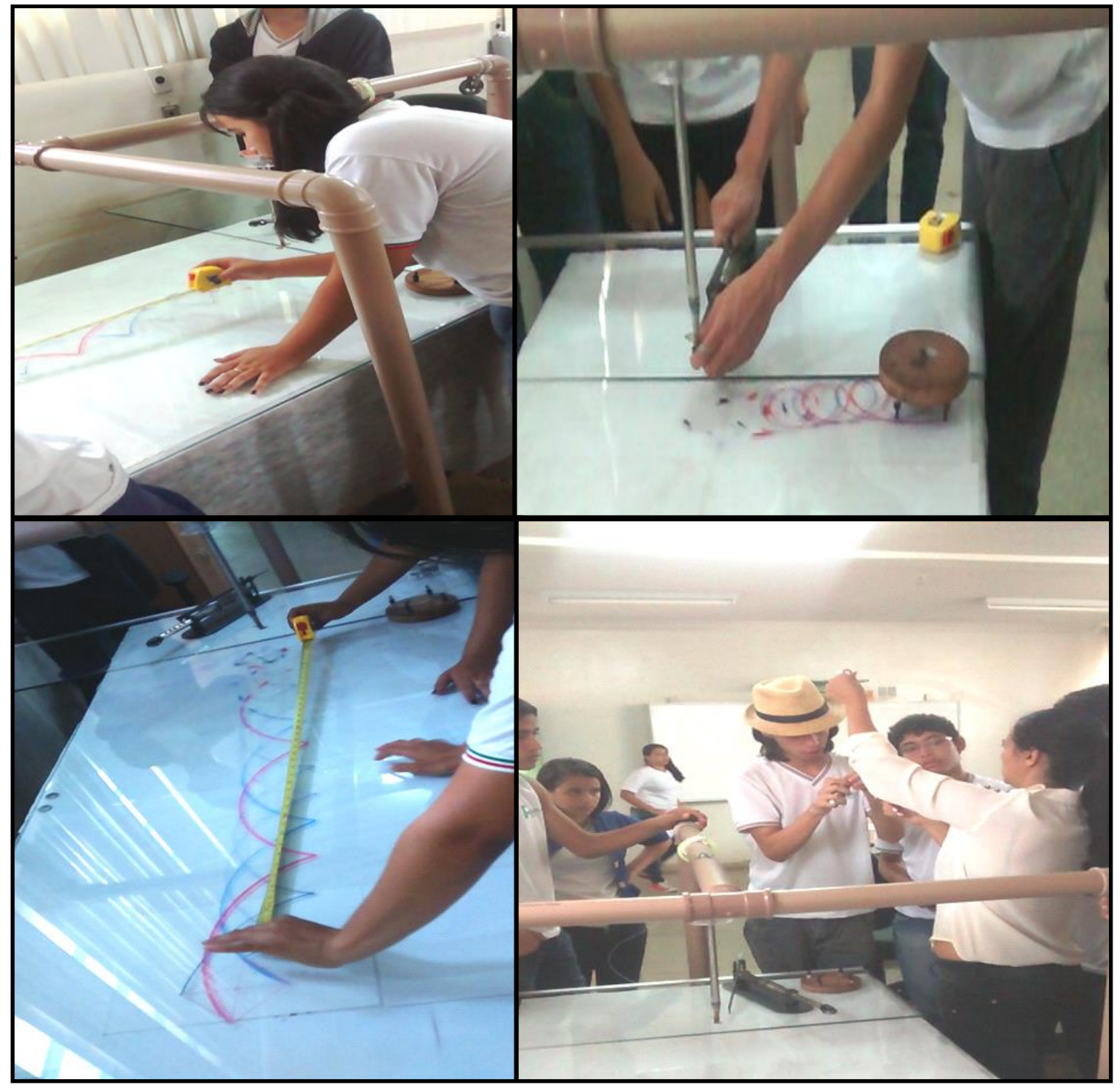

Figura 15: alunos analisando trajetórias descritas pelo carrinho. 
Pré-ensaio: cada subgrupo deve envolver-se com apenas uma das seguintes atividades:

1 - Medir a massa do peso que vai ser suspenso e a altura da qual ele será solto em relação ao ponto de apoio. Medir o raio e a massa do carrinho. Obs: a medida da altura de deslocamento deve ser realizada sempre usando o mesmo ponto de referência no corpo do peso suspenso.

2 - Medir a constante elástica da mola. Procedimento: engate um dinamômetro na mola do ferrolho e puxe no sentido de contração da mola, registrando a deformação da mola e a força que o dinamômetro marca em cada deslocamento. Façam no mínimo quatro medidas, montem uma tabela e, utilizando a fórmula da força elástica $(F=k . x)$, calcule a constante elástica da mola. Faça uma média aritmética com os resultados e utilize esse valor, quando precisar da constante elástica da mola $(k)$.

3 - Medir o coeficiente de atrito (estático) da superfície por onde o carrinho deslizou. Procedimentos: (i) escolha um peso, coloque sobre o carrinho, engateo no dinamômetro e tente puxar o carrinho sobre a superfície até o momento que você conseguir tirá-lo do lugar, (ii) registre esta força e a massa do peso que foi puxado. Este procedimento deve ser repetido no mínimo quatro vezes com pesos diferentes. Calcule o coeficiente de atrito da superfície utilizando a formula $(F=\mu . N)$ e monte uma tabela. Faça uma média aritmética com os resultados e utilize esse valor quando precisar do coeficiente de atrito estático da superfície.

\section{Guia 2}


Ensaio: todos os grupos devem executar estas atividades.

4 - Amarre o peso que deseja levantar no fio, enrole o fio no carretel até que o peso atinja a altura desejada para o ensaio, segure com uma mão o eixo rotor (abaixo do carretel) e engate o carrinho.

5 - Posicione o ferrolho em uma posição que favoreça atingir o carrinho no momento que ele tocar a superfície rugosa, use ventosas para fixá-lo nesta posição e trave a haste do ferrolho, comprimindo a mola na posição desejada para o ensaio.

6 - Solte o eixo rotor. No momento em que o carrinho se soltar e atingir a superfície rugosa, acione o ferrolho.

Obs: Para executar o ensaio será necessária a participação de, no mínimo, dois alunos, um para colocar o peso, enrolar o fio no carretel, segurar o eixo rotor, engatar o carrinho e depois soltar o eixo rotor no momento adequado, e outro para posicionar e fixar o ferrolho, travar a haste do ferrolho e desengatá-lo no momento adequado. Este processo de desengate/liberação do ferrolho tem que ser treinado com antecedência para melhorar o tempo de reação de modo que a haste do ferrolho bata no carrinho assim que ele cair sobre a superfície.

7 - Com a trajetória marcada, ligar os quatro pontos de saída deixada pelos pés do carrinho e marcar o centro do carrinho, repetir o mesmo processo nos pontos de chegada. Estime, com o auxílio do desenho marcado na superfície rugosa, quantas voltas o carrinho pode ter executado.

8 - Medir a distância entre o centro do carrinho, no ponto de saída, até o ponto de chegada da trajetória descrita por ele. Essa distância será utilizada para calcular o trabalho da força de atrito do movimento de translação.

9 - Coloque barbante sobre o desenho traçado na superfície rugosa, acompanhando o formato do desenho e meça o comprimento traçado por cada pé separadamente. Calcule a média dessas medidas. Essa distância será utilizada para calcular o trabalho envolvendo o movimento de translação e rotação, ou seja, o trabalho total.

\section{Guia 2 (continuação)}




\section{Quinta etapa}

Nas etapas anteriores do trabalho, os alunos analisaram ativamente todo o aparato, debateram com os colegas os conceitos físicos envolvidos no experimento, fizeram medidas, discutiram possíveis resultados e colocaram o aparato para funcionar. Para obter as grandezas físicas necessárias para a análise conceitual, os alunos receberam outra sequência de atividades (guia 3).

Na quinta etapa, os estudantes fizeram a análise conceitual. Os discentes foram instigados a analisar as atividades e discuti-las com os colegas (figura 16). Fiz algumas considerações para facilitar a integração dos conceitos físicos, as expressões matemáticas e o funcionamento do aparato. Dentre elas, a exposição no quadro negro das expressões matemáticas e a relação dessas com os conceitos relevantes para a descrição do funcionamento do aparato experimental. Os alunos realizaram as atividades de análise em grupo e fizeram os cálculos individualmente. Após a realização dos cálculos, recolhi os resultados da atividade para realizar uma análise qualitativa do trabalho. 
Segunda parte: análises e discussões envolvendo o grande grupo e resolução individual.

Pós-experimental

1 - Realize as seguintes tarefas:

a) Calcule a energia potencial gravitacional associada ao peso suspenso.

b) Calcule a energia potencial elástica da mola.

c) Calcule o trabalho da força de atrito no deslizamento do carrinho.

d) Relacione as energias calculadas nos itens a e b com o trabalho calculado.

e) Discuta os resultados com os colegas e anote as possíveis conclusões.

2- Considere, nas tarefas abaixo, a situação ideal na qual as energias são completamente conservadas nos respectivos processos de transformação.

a) Calcule o momento de inércia do carrinho.

b) Estime a velocidade de rotação do carrinho no instante em que atinge a superfície rugosa.

c) Estime a velocidade de translação do carrinho no instante em que recebe o impacto da haste do ferrolho.

\section{Guia-3}


A seguir, expomos, a título de exemplo, os resultados encontrados em um dos ensaios.

Dado: aceleração da gravidade local: $g=9,80 \mathrm{~m} / \mathrm{s}^{2}$.

Medidas diretas:

a) Massa do peso suspenso: $m_{p}=0,25 \mathrm{~kg}$.

b) Raio do carrinho: $R_{c}=0,070 \mathrm{~m}$.

c) Massa do carrinho: $m_{c}=0,17 \mathrm{~kg}$.

d) Altura de suspensão do peso: $h=0,85 \mathrm{~m}$.

e) Elongação da mola: $x=0,08 \mathrm{~m}$.

f) Média da distância total percorrida pelos pés do carrinho:

$$
d=\frac{1,50+1,42+1,41+1,44}{4}=1,44 \mathrm{~m}
$$

g) Tabela construída para calcular a constante elástica da mola.

\begin{tabular}{|l|l|l|l|}
\hline$F(\mathrm{~N})$ & $x(\mathrm{~m})$ & $k(\mathrm{~N} / \mathrm{m})$ & Média aritmética \\
\hline 19,8 & 0,030 & 660 & \\
\hline 24,5 & 0,037 & 662 & \\
\hline 29,4 & 0,048 & 613 & \\
\hline 39,2 & 0,065 & 603 & \\
\hline 44,1 & 0,069 & 639 & $635 \mathrm{~N} / \mathrm{m}$ \\
\hline
\end{tabular}

h) Tabela construída para calcular o coeficiente de atrito entre o vidro e o carrinho.

\begin{tabular}{|l|l|l|l|}
\hline$F(\mathrm{~N})$ & $N(\mathrm{~N})$ & $\mu$ & Média aritmética \\
\hline 0,40 & 1,96 & 0,20 & \\
\hline 0,50 & 2,94 & 0,17 & \\
\hline 0,70 & 3,92 & 0,18 & \\
\hline 0,80 & 4,90 & 0,16 & 0,18 \\
\hline
\end{tabular}


Cálculo das quantidades físicas relevantes:

a) Momento de inércia do carrinho:

$$
I=\frac{1}{2} m_{c} R_{c}{ }^{2}=\frac{1}{2}(0,17)(0,070)^{2}=4,2 \times 10^{-4} \mathrm{~kg} \cdot \mathrm{m}^{2}
$$

b) Energia potencial gravitacional:

$$
E_{\text {potg }}=m_{p} g h=(0,25)(9,80)(0,85)=2,1 \mathrm{~J}
$$

c) Energia potencial elástica:

$$
E_{\text {potk }}=\frac{1}{2} k x^{2}=\frac{1}{2}(635)(0,08)^{2}=2 \mathrm{~J}
$$

d) Trabalho efetuado pelas forças de atrito da superfície:

$$
W=F_{a t} d=\mu m_{c} g d=(0,18)(0,17)(9,80)(1,44)=0,43 \mathrm{~J}
$$

Análise dos resultados.

A comparação entre o trabalho realizado pelas forças de atrito no deslizamento com as energias potenciais estocadas na configuração mostra que a maior parte da energia inicialmente disponível $(4 \mathrm{~J})$ foi perdida nas partes móveis do sistema ( $4-0,43=3,57 \mathrm{~J}$ ), ou seja, da ordem de $90 \%$ ! Portanto, a eficiência desse dispositivo é de, aproximadamente,

$$
\eta=\frac{F_{a t} d}{E_{p o t g}+E_{p o t k}}=\frac{0,43}{4} \cong 11 \%
$$

Isso demonstrou, para os alunos, como as perdas envolvidas em todos os passos de operação do dispositivo são, em geral, extremamente altas e que ele, para operar com mais eficiência, precisaria passar por sensíveis melhoramentos técnicos.

Evidentemente, todos os ensaios produziram resultados bastante similares. A reação dos alunos foi interessante, pois eles ficaram tão surpresos 
com a baixa eficiência que começaram a pensar que haviam cometido erros nos cálculos. Isso propiciou uma boa discussão. Eles já sabiam, é claro, que o princípio de conservação da energia mecânica não seria exatamente verificado, mas não tinham ideia de como as idealizações envolvidas no tratamento de situações físicas podem mostrar-se muito diferentes de sua verificação prática. Além disso, e evidenciei o problema de se conseguir bons rendimentos até mesmo em dispositivos de alta tecnologia. Como exemplo, citei o rendimento médio de motores à gasolina, que não passam dos $35 \%$.

Vários outros testes foram feitos utilizando-se óleo lubrificante nas partes móveis do ferrolho e na junção entre o eixo rotor e a barra de sustentação, além de pó de grafite na reentrância de conexão do carrinho. Mesmo assim, não foi possível conseguir aumento significativo nos rendimentos.

Desse modo, os resultados foram altamente significativos, do ponto de vista pedagógico, já que, além de demonstrarem as grandes dificuldades encontradas no âmbito da técnica para eliminar as perdas energéticas, apresentaram uma boa oportunidade para instigar os estudantes a procurarem justificativas para os resultados e montarem argumentos convincentes das razões pelas quais os fatos contrariavam as situações ideais onde costuma-se aplicar as leis da física. As figuras 17, 18 e 19 ilustram mais alguns ensaios realizados. 

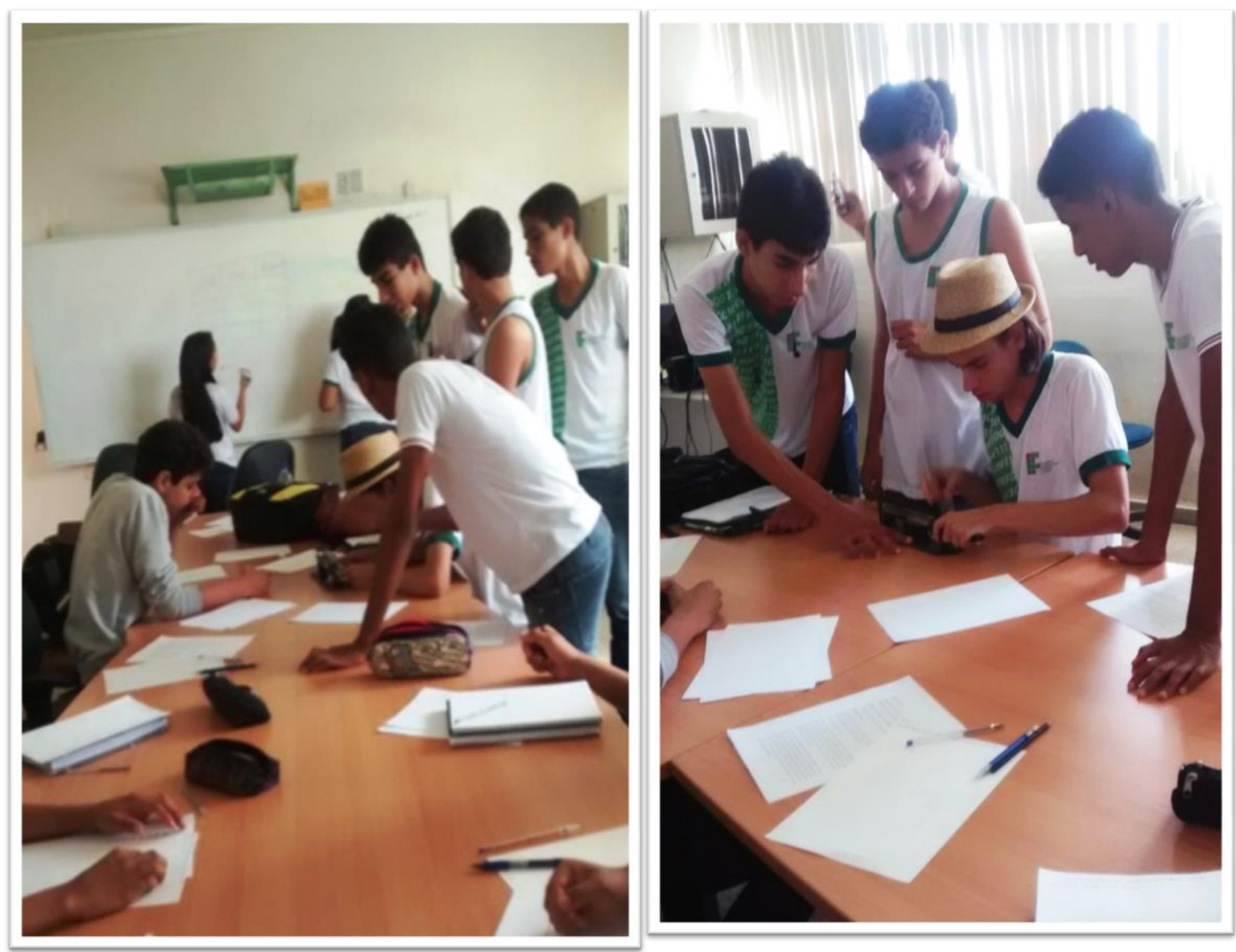

Figura 16: alunos discutindo as tarefas do guia 3 


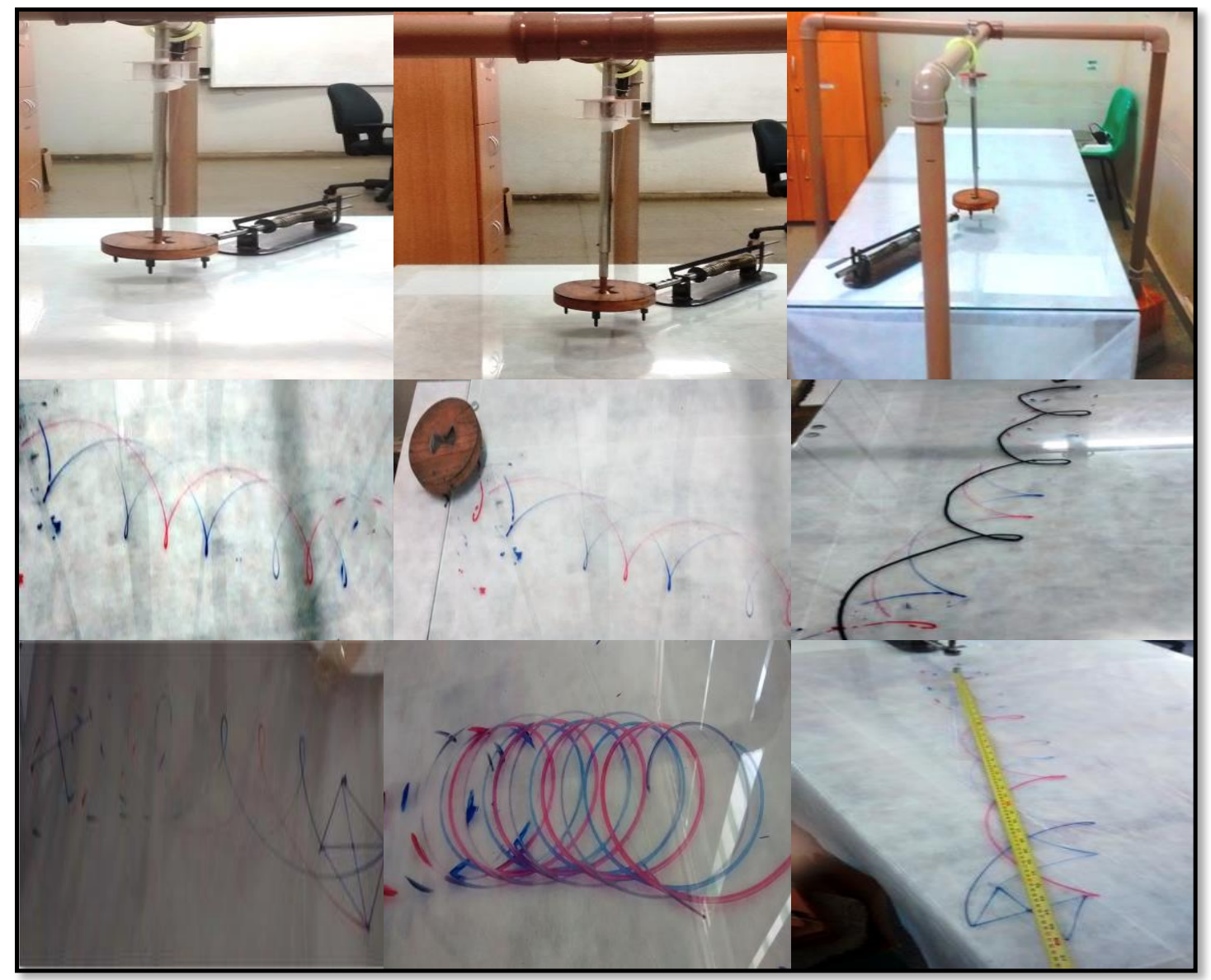

Figura 17: Aparato em funcionamento e registro de algumas trajetórias 


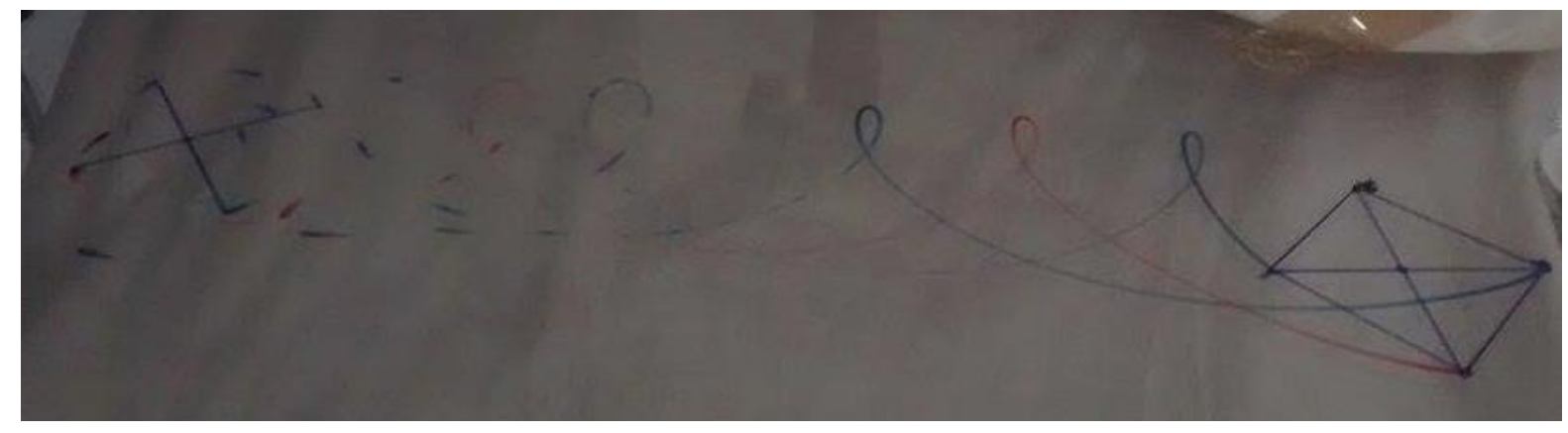

Figura 18: Trajetória analisada no exemplo

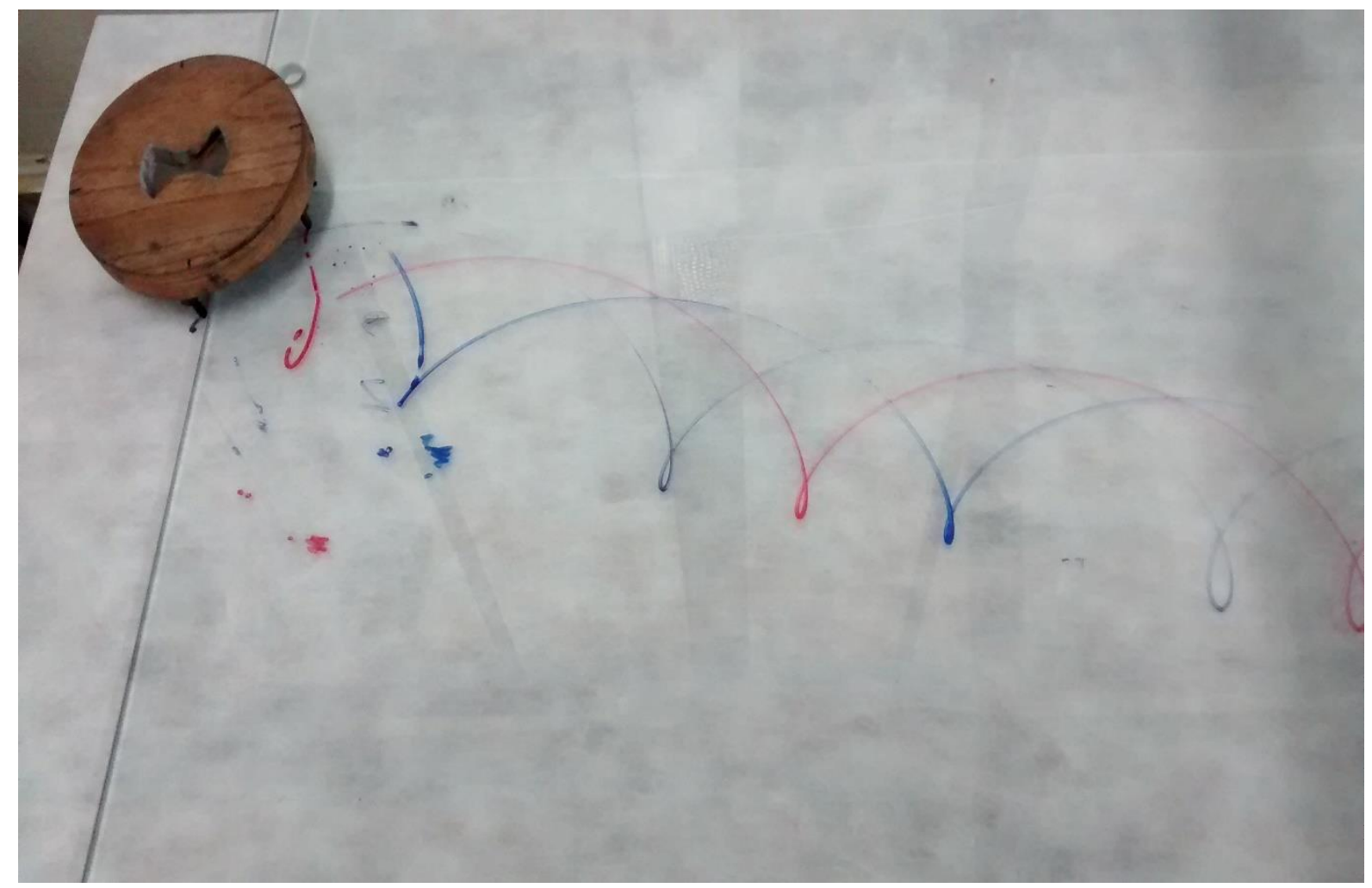

Figura 19: outra trajetória descrita pelo carrinho. 


\section{Sexta etapa}

Nessa etapa, a tarefa dos alunos foi a construção de um mapa conceitual (pós-teste), abordando os conceitos que foram estudados durante todo o evento educativo, sobre os aspectos relacionados com o tema da energia: conservação, transformação, dissipação e trabalho.

Posteriormente, na etapa de avaliação, esse tipo de recurso didático foi utilizado como instrumento de avaliação de aprendizagem, a partir de uma análise qualitativa e subjetiva. Antes da construção dos mapas conceituais pósteste, os alunos foram instigados a discutir sobre todas as observações e as análises realizadas ao longo do desenvolvimento do trabalho.

Para finalizar, os estudantes responderam a um questionário visando avaliar a estratégia. Tal questionário não foi elaborado para avaliar a aprendizagem, e sim o grau de receptividade dos alunos à nova abordagem, quando comparada com aquelas tradicionalmente empregadas em sala de aula (guia 4). Os resultados desse questionário são apresentados na próxima seção. 
Questionário de avaliação de receptividade destinado aos alunos que participaram do evento educativo.

1 - O arranjo experimental utilizado durante as aulas foi importante para você entender as relações entre as transformações de energia, sua dissipação e o trabalho.
a) concordo plenamente.
b) discordo.
c) concordo com restrições.
d) discordo plenamente.
e) concordo.

2 - Você classifica o método utilizado pela professora para abordar este conteúdo como:
a) péssimo.
b) regular.
c) bom.
d) muito bom.
e) excelente.

3 - Classifique as opções abaixo de 1 a 4, segundo o grau crescente de importância. 0 que foi mais útil para você durante o processo de desenvolvimento das aulas?

( ) As aulas expositivas do professor na sala de aula.

( ) As aulas de manipulação do aparato experimental e as medidas feitas.

( ) As aulas onde foram discutidos e analisados os resultados observados.

( ) As aulas onde foram construídos os mapas conceituais.

4 - Esse conteúdo abordado (conservação, dissipação, transformação de energia e trabalho) é importante para minha vida.
a) discordo plenamente.
b) concordo com restrições.
c) concordo plenamente.
d) concordo.
e) discordo.

5 - Acredito que, se nas aulas de física, fossem utilizados mais experimentos onde os alunos pudessem manusear o aparato, fazer medidas, construir tabelas e gráficos, 0 ensino/aprendizagem se tornaria mais fácil e interessante.
a) concordo plenamente.
b) discordo.
c) concordo com restrições.
d) discordo plenamente.
e) concordo.

6 - Acredito que aprendo mais física quando os conteúdos são ensinados com ajuda de experimentos e discussões em grupos. Dessa maneira, fica mais fácil entender a relação entre as expressões matemáticas e os conceitos físicos estudados.
a) discordo.
b) concordo com restrições.
c) discordo plenamente.
d) concordo.
e) concordo plenamente.

7 - Dê sua opinião sobre as aulas ministradas com o aparato experimental.

\section{Guia 4}




\subsection{Avaliação de aprendizagem, crítica e conclusões.}

Não faz parte desse estudo uma avaliação quantitativa criteriosa do resultado da aplicação do produto educacional desenvolvido, pois sabemos que não é possível avaliar o impacto de quaisquer métodos ou instrumentos didáticos com base em apenas um evento educativo. Validações exigem análises estatísticas que requerem uma base de dados coletados muito mais ampla, o que implicaria a necessidade de aplicar o produto durante vários períodos letivos, para várias turmas e, de preferência, utilizando grupos de controle.

De fato, nem mesmo uma análise qualitativa criteriosa é possível, nessas condições. Contudo, é ainda válida uma reflexão com base no desempenho observado dos alunos que foram submetidos ao evento educativo relatado nessa dissertação. Como já dissemos acima, o instrumento escolhido para isso foram os mapas conceituais e uma pesquisa de receptividade. Ainda assim, devemos lembrar que, de certa forma, o maior objetivo (implícito) desse trabalho é o de compartilhar experiências vivenciadas em sala de aula com a utilização do aparato experimental desenvolvido. Com relação a isso, consideramos ter sido o evento educativo altamente bem-sucedido.

Nessa experiência de aprendizagem, os conteúdos envolvendo o conceito de energia, o princípio de conservação da energia mecânica, suas transformações, os processos de dissipação e o trabalho das forças de atrito foram abordados juntamente com experimentação concreta. Com relação a isso, é importante salientar que os conceitos foram abordados e analisados tanto de forma qualitativa quanto quantitativa, isto é, sem nos eximirmos de realizar as conexões necessárias com as expressões matemáticas que os definem. Acreditamos, ainda, que a estratégia utilizada proporcionou um ambiente de ensino e aprendizagem favorável a desenvolver nos alunos o interesse de aprender de maneira efetiva. Afinal, para que aconteça uma aprendizagem significativa, o aluno tem que estar predisposto a aprender e o material didático utilizado tem que ser relacionável à sua estrutura cognitiva, ou seja, tem que ser potencialmente significativo.

Ao analisar os questionários de avaliação de receptividade respondidos pelos alunos (guia 4) e levar em conta as observações realizadas, durante todo 
o evento educativo, foi possível constatar que quase todos os estudantes acreditam que a utilização de uma abordagem fisicamente e vivencialmente concreta - ou seja, com experimentos ativos e contextualizados na realidade dos alunos -, permite que os conceitos da física se tornem muito mais fáceis de serem compreendidos. Os alunos abordaram a importância das discussões em grupo, sob supervisão do professor, relatando que abordagens diferentes enriquecem o estudo e os incentiva a pesquisar mais sobre o assunto. Outra opinião bem comum entre os alunos que participaram do evento educativo é a de que as aulas de física quase sempre são apenas teóricas e, ainda quando assistem a aulas experimentais, elas são, em geral, desconectadas da teoria. Como consequência, quando não entendem os conceitos teóricos, os experimentos acabam ficando sem sentido e, frequentemente, não ajudam os estudantes a entender os conteúdos e a assimilar os conceitos. De fato, alguns alunos relataram que nunca tinham participado de uma aula de física onde os conceitos tivessem sido ensinados juntamente com uma situação experimental, tendo destacado que as aulas ficaram mais interessantes.

Apesar de todas essas respostas positivas, o que consideramos ter sido realmente digno de destaque foi o relato espontâneo dos estudantes de que, todas as vezes que tivessem a necessidade de recordar e utilizar os conceitos abordados - com ou sem menção às suas definições matemáticas - em contextos de avaliação ou de exercício, eles haveriam de se recordar do experimento e das vivências de sua aplicação. Interpretamos esse fato como um forte indício de que o evento educativo tenha proporcionado o que tanto se busca - uma aprendizagem significativa - já que, ao que tudo indica, algum grau de modificação de subsunçores parece ter sido alcançado. Como mencionado abaixo, esse mesmo indício revelou-se na construção dos mapas conceituais aplicados para a avaliação de aprendizagem (pós-teste).

É importante que se saliente que não nos parece ser o caso de identificar, com qualquer nível de rigor, exatamente que subsunçores foram esses. Para realizar uma avaliação dessa natureza, seria necessário fazer uma ampla e sistemática investigação dos conhecimentos prévios dos alunos, algo que, dadas as condições de aplicação, o tempo disponível e os objetivos desse trabalho, esteve, definitivamente, fora de cogitação. A única coisa que, talvez, ainda seria 
possível fazer seria uma especulação, com base nos mapas conceituais previamente aplicados. Contudo, a qualidade desses mapas conceituais deixou muito a desejar e dificilmente eles apresentam qualquer elemento mais sólido para se realizar até mesmo uma especulação minimamente balizada. Por isso, nos abstivemos de fazer qualquer estudo nessa direção.

Em relação à avaliação dos alunos sobre os aspectos didáticos (organização, instrumentos de avaliação, atividades propostas) envolvidos em todo o trabalho, a maioria dos participantes avaliou a estratégia utilizada para abordar o conteúdo como ótima, destacando a importância de utilizar experimentos para que as aulas fiquem mais dinâmicas, o que os deixou mais estimulados a continuar participando ativamente das tarefas.

O recurso empregado para avaliar o desempenho dos alunos no evento educativo, no que se refere ao seu aprendizado, foram os mapas conceituais. Eles revelaram que quase todos os alunos que participaram do trabalho conseguiram alcançar desempenhos relativamente bons na estruturação de seus respectivos mapas conceituais. Eles conseguiram integrar a parte qualitativa dos conceitos com suas expressões matemáticas de forma mais clara e hierárquica, sempre se baseando no funcionamento do aparato (figuras 20 a 26, mapas à direita).

Muitos alunos, além de organizar as informações no mapa, procuraram escrever um pequeno texto sobre o funcionamento do aparato experimental, em particular, abordando as questões conceituais relacionadas com o problema das perdas de energia nas partes móveis do aparelho. Como esses pequenos textos foram feitos de maneira espontânea e apresentaram-se relativamente corretos, temos, com isso, outro indício de que o conteúdo deve ter sido compreendido e assimilado com alguma propriedade.

O objetivo da avaliação utilizando mapas conceituais não foi o de classificar quantitativamente, mas sim o de obter informações sobre o tipo de estrutura hierarquizada de conceitos os alunos conseguiam construir. Ou seja, que tipos de estrutura de relações integradoras dos conceitos estudados foram desenvolvidos. Tais estruturas, quando corretas, do ponto de vista do conhecimento aceito, são também indícios de aprendizagem significativa. 
Também fizemos uma comparação entre os mapas construídos no préteste e no pós-teste. Essa comparação demonstrou melhora substancial (figuras 20 a 26, mapas à direita: pós-teste, mapas à esquerda: pré-teste). Sabemos, contudo, que essa melhora no desempenho não reflete um desempenho diferencial no que se refere à comparação entre uma exposição tradicional e a abordagem utilizada por nós, já que uma minoria dos alunos realmente havia sido exposta a esse conteúdo, previamente.

Portanto, foi possível obter informações que deixaram evidente 0 aprendizado das ideias principais. Dos trinta e dois alunos que iniciaram o trabalho, vinte e oito o concluíram, já que quatro deles foram transferidos do Instituto no decorrer da aplicação. Assim, contamos com vinte e oito mapas conceituais para avaliar. Desses, cerca de oito apresentaram desempenho considerado excelente e doze, desempenho considerado bom. Seis deles tiveram desempenho regular e apenas dois apresentaram desempenho ruim. Contudo, é relevante destacar que esses últimos alunos, durante todo 0 desenvolvimento do trabalho, estavam muito dispersos e não participaram ativamente das discussões, mesmo tendo sido convidados várias vezes a contribuir com os trabalhos do grupo. Já os demais, durante as etapas do trabalho, demonstraram-se empolgados e curiosos para realizar cada atividade e chegar às observações e conclusões finais.

Podemos, por fim, fazer uma consideração de caráter crítico com relação à aplicação acima relatada, com o objetivo de orientar futuras aplicações que venham a ser realizadas. Trata-se do modo como foi conduzida e organizada a primeira e segunda etapas de aplicação. É parte crucial da filosofia desse trabalho a ideia de que os conceitos da física são melhor ensinados e aprendidos se os seus aspectos quantitativos e qualitativos, experimentais e teóricos forem abordados e trabalhados em uma estrutura integrada. Por isso, talvez seja conveniente fazer uso de uma estratégia de ensino "pendular", segundo a qual oscila-se entre uma apresentação qualitativa e uma quantitativa dos conceitos, sempre procurando aprofundar, a cada passo, os níveis de complexidade e abrangência, até o ponto em que o objetivo final, que é a construção completa de um conceito, seja alcançada. 
Por esses motivos, uma apresentação qualitativa dos conceitos, já no primeiro contato dos alunos com o aparato experimental, antes mesmo de terem sido expostos a qualquer explicação teórica, parece-nos a melhor estratégia. Não é necessário que os alunos manipulem o experimento nesse momento, mas uma explanação teórica fundada no funcionamento do aparato nos parece um bom ponto para se começar. A ideia é que, na sequência, o professor se utilize de uma ou mais aulas teóricas expositivas para começar a prover as definições quantitativas dos conceitos previamente expostos, antes de retornar ao experimento. Quando isso vier a acontecer, a ideia é que os alunos comecem a estabelecer relações intuitivas entre os fenômenos que instanciam os conceitos e suas definições matemáticas. Embora mapas conceituais possam ser utilizados para uma sondagem dos conhecimentos prévios dos alunos, conforme fizemos, é também interessante aplicá-los em etapas intermediárias, de modo a prover organização paulatina e acompanhamento de desempenho, até a etapa final, quando uma avaliação comparativa pode ser feita de modo realmente significativo.

\section{Análise comparativa de alguns mapas conceituais}

A seguir, faremos uma análise comparativa da evolução dos mapas conceituais de alguns alunos, tomados como amostra ilustrativa. Faremos a comparação entre os mapas pré e pós-teste, ambos correspondendo ao mesmo aluno, em cada caso mostrado nas figuras 20 a 26

Com relação ao aluno da figura 20 , foi possível verificar que, no pós-teste, o aluno explica de maneira clara e organizada alguns conceitos que, no préteste, nem sequer foram lembrados, a saber: energia potencial gravitacional, energia cinética de rotação e de translação. Foi observado também um crescimento em relação à organização de alguns conceitos que apareceram nos dois mapas, são eles: energia potencial elástica e força elástica. No pós-teste, foi possível verificar que o aluno adquiriu aprendizado em relação ao princípio de conservação de energia e trabalho, em relação ao pré-teste. De fato, podemos verificar uma diferença significativa na organização dos conceitos, em 
relação aos dois mapas, mas isso não significa que outros avanços não devessem ser feitos para consolidar ainda mais o seu aprendizado.

Com relação ao aluno da figura 21, foi possível perceber que, no pósteste, o aluno demonstra conhecimento claro e organizado sobre: a energia potencial gravitacional e elástica, energia cinética de translação e rotação. No pré-teste, esses conceitos não aparecem. O aluno aborda somente a energia potencial elástica. No pós-teste, o aluno demonstrou que o conceito de momento de inércia ainda estava em construção, bem como o conceito de transformação de energia em trabalho, mas podemos perceber um crescimento em relação ao pré-teste, pois, nele, o conceito nem sequer foi mencionado. Por esses motivos, concluo que os dois mapas conceituais deixam evidências de que o aluno realmente demonstrou uma melhora substancial em seu aprendizado de maneira mais clara e organizada.

Ao comparar o mapa conceitual pré e pós-teste do aluno da figura 22 , foi possível verificar que, no pós-teste, o aluno demonstrou entendimento ao relacionar a energia mecânica com a energia cinética e energia potencial, ao relacionar a transformação de energia com trabalho (apresentando a expressão matemática), ao citar a impossibilidade de se conseguir $100 \%$ de rendimento com as máquinas. No pré-teste, não se verifica conhecimento sobre esses conceitos, apenas é citado algo sobre a energia potencial elástica. Com isso, foi possível perceber que o aluno demonstrou um crescimento em relação aos conceitos trabalhados, mas ainda precisava melhorar a organização dos conceitos de forma a que eles fizessem mais sentido.

Ao comparar os mapas conceituais do aluno da figura 23 , foi possível constatar, no mapa pós-teste, que o aluno demonstrou ter aprendido de maneira clara e organizada, vários conceitos trabalhados, a saber: energia potencial gravitacional e elástica, energia cinética de rotação e translação, conservação de energia e trabalho da força de atrito. No pré-teste, o aluno demonstrou algum entendimento sobre o assunto, mas não conseguiu estabelecer uma relação coerente entre eles. $O$ aluno demonstrou ter adquirido um aprendizado que possibilitou organizar os conceitos de maneira hierárquica e clara e isso pode 
ser uma evidência de aprendizagem que provocou uma reestruturação nos conceitos prévios de maneira a acomodar o conceito novo adquirido.

Ao comparar os mapas conceituais do aluno da figura 24, foi possível constatar que, no pós-teste, ele demonstrou uma organização coerente, deixando bem notável que entendeu os conceitos de energia potencial gravitacional e elástica, força de atrito e conservação de energia, de maneira bem clara e organizada. No pré-teste, o aluno demonstrou que não tinha conhecimento claro sobre esses conceitos e se limitou a montar o mapa de maneira aleatória, sem nenhuma sequência lógica. Com isso, pude constatar que esse aluno demonstrou um crescimento substancial em relação à quantidade de conceitos aprendidos, de maneira hierárquica e organizada, e isso pode ser interpretado também como aprendizagem significativa.

Ao comparar os mapas conceituais do aluno da figura 25, foi possível verificar, que no pós-teste, o aluno demonstrou entendimento, de maneira clara e organizada, dos conceitos: energia cinética, conservação de energia, trabalho, força de atrito, energia potencial gravitacional e elástica. No pré-teste, muitos desses conceitos fizeram parte da constituição do mapa, mas não estão organizados de maneira a demonstrar uma relação estruturada e clara, onde fosse possível identificar conhecimento. Assim, pude constatar que o aluno demonstrou ter aprendido o conteúdo de maneira a causar uma modificação na estruturação dos conceitos que já possuía, de forma efetiva e organizada.

Ao comparar os mapas conceituais do aluno da figura 26 , foi possível verificar, no pós-teste, que o aluno demonstrou um entendimento organizado e claro em relação aos conceitos de: energia potencial gravitacional e elástica, energia cinética de rotação e translação, trabalho e força de atrito. No pré-teste, também conseguimos verificar algum conhecimento prévio, mas de uma maneira bem menos estruturada e com pouca informação sobre o assunto. Assim, pude constatar que esse aluno demonstrou um crescimento em relação à estruturação dos conceitos prévios e apropriação de novos conceitos de maneira efetiva. 


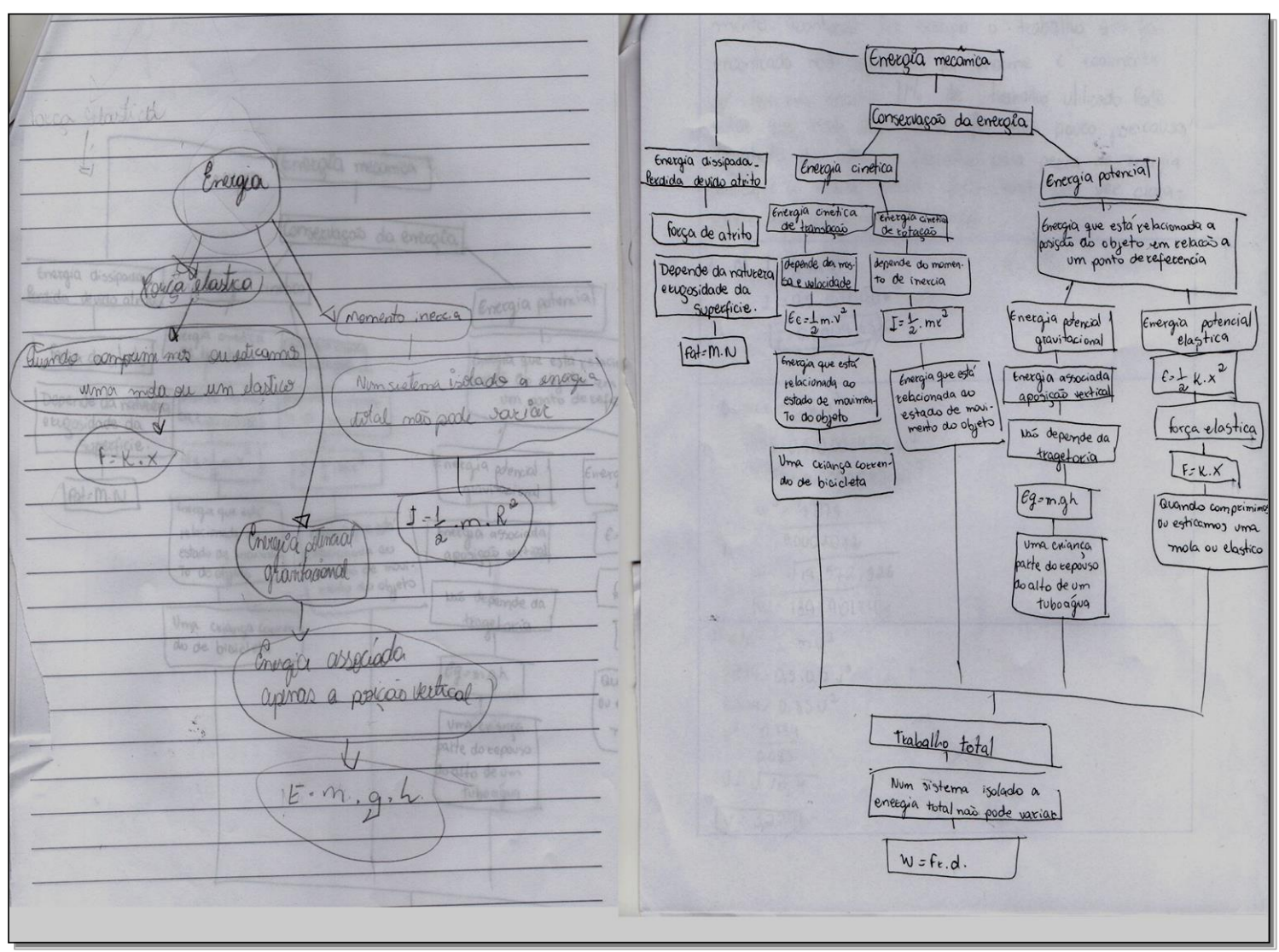

Figura 20: mapas conceituais produzidos pelos alunos. À direita: pós-teste. À esquerda: pré-teste. 


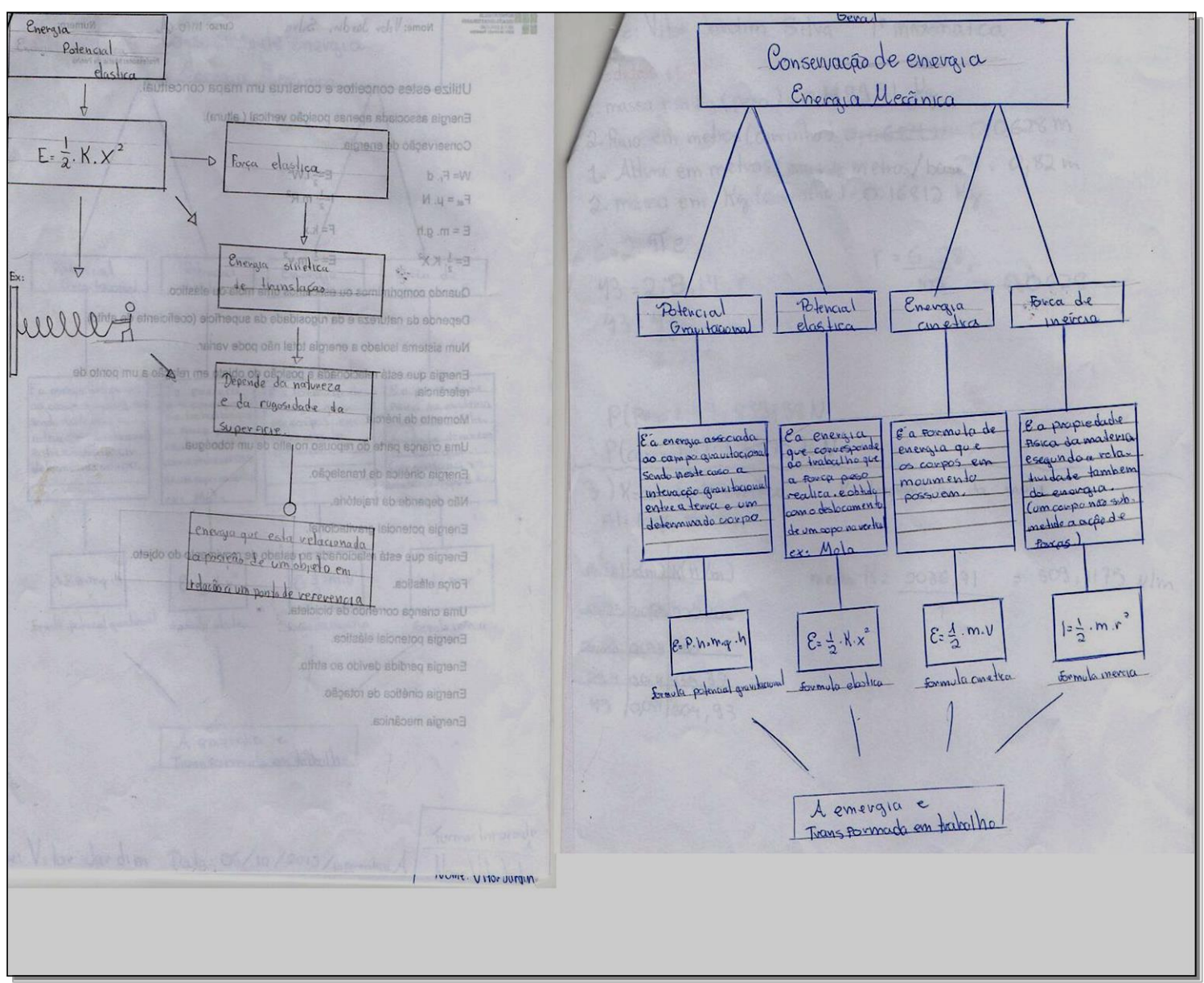

Figura 21: mapas conceituais produzidos pelos alunos. À direita: pós-teste. À esquerda: pré-teste. 


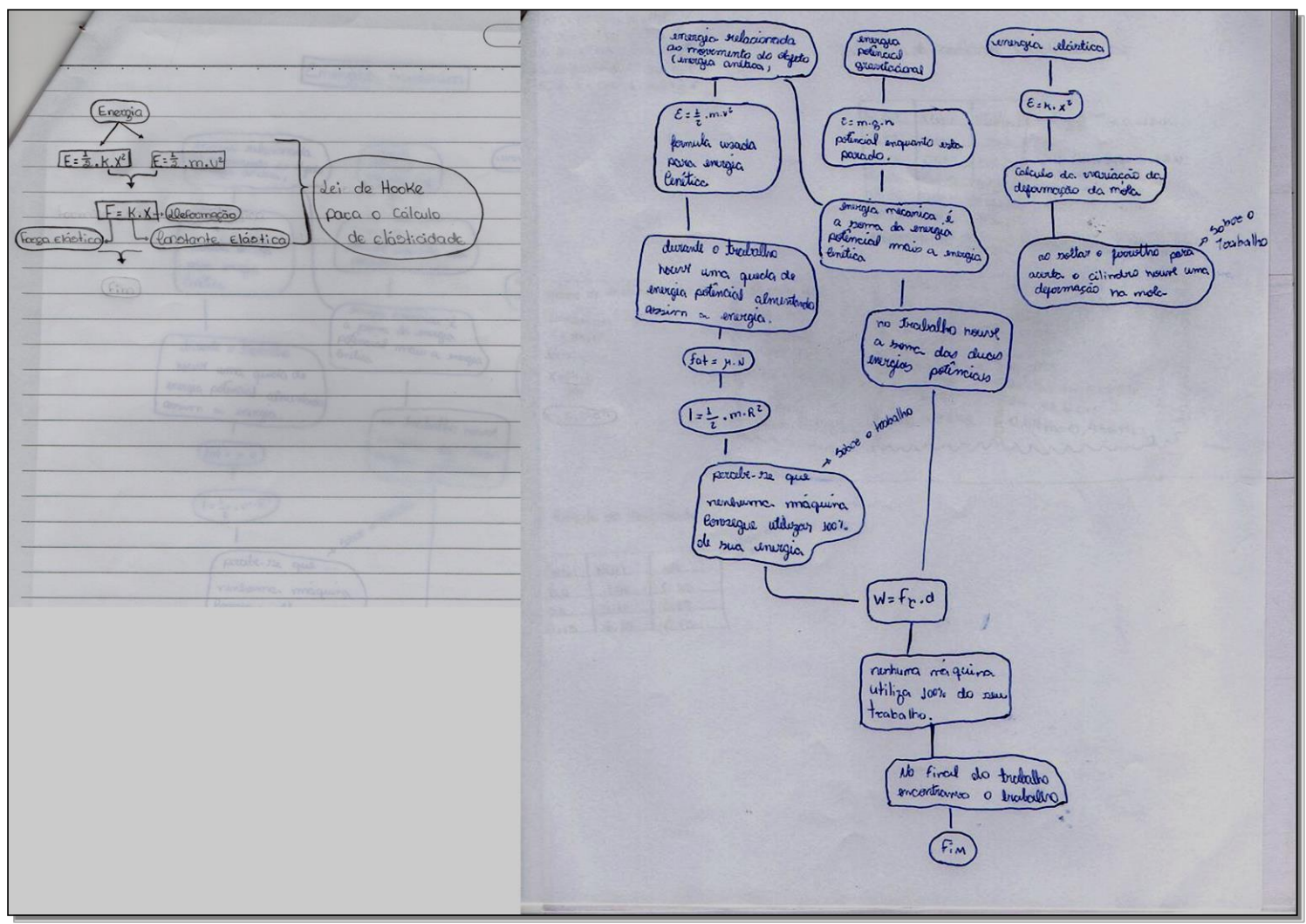

Figura 22: mapas conceituais produzidos pelos alunos. À direita: pós-teste. À esquerda: pré-teste. 


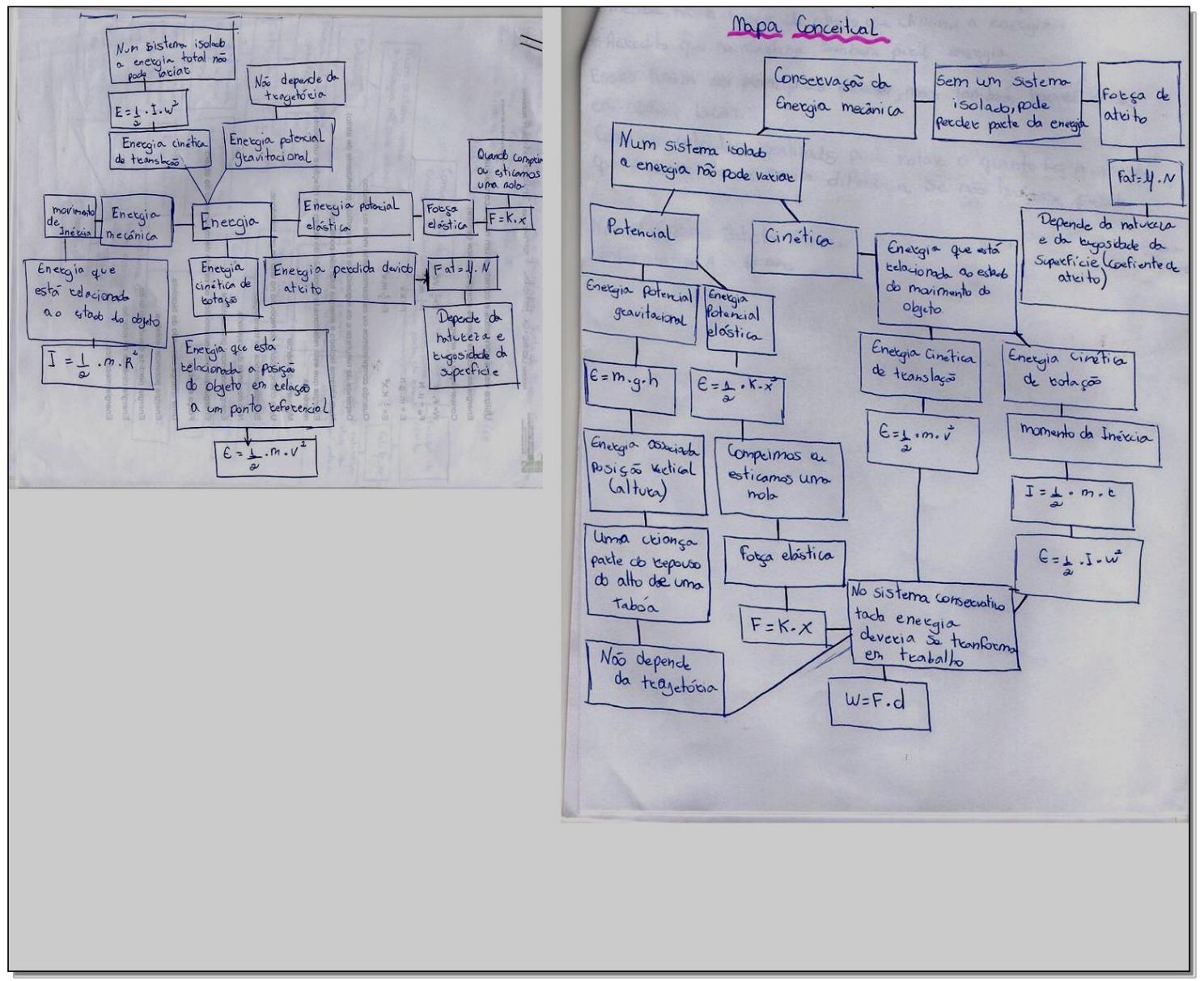

Figura 23: mapas conceituais produzidos pelos alunos. À direita: pós-teste. À esquerda: pré-teste. 


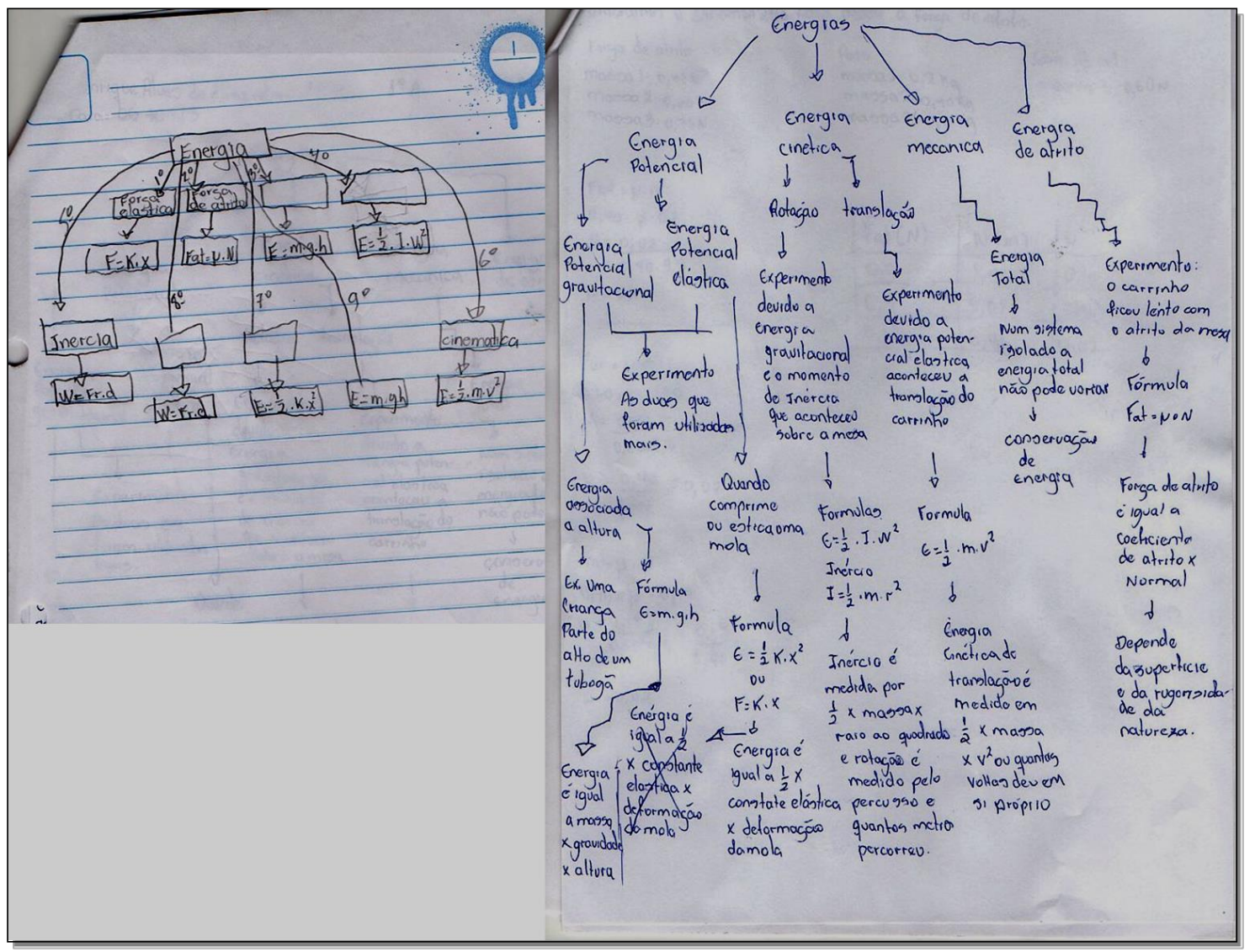

Figura 24: mapas conceituais produzidos pelos alunos. À direita: pós-teste. À esquerda: pré-teste. 


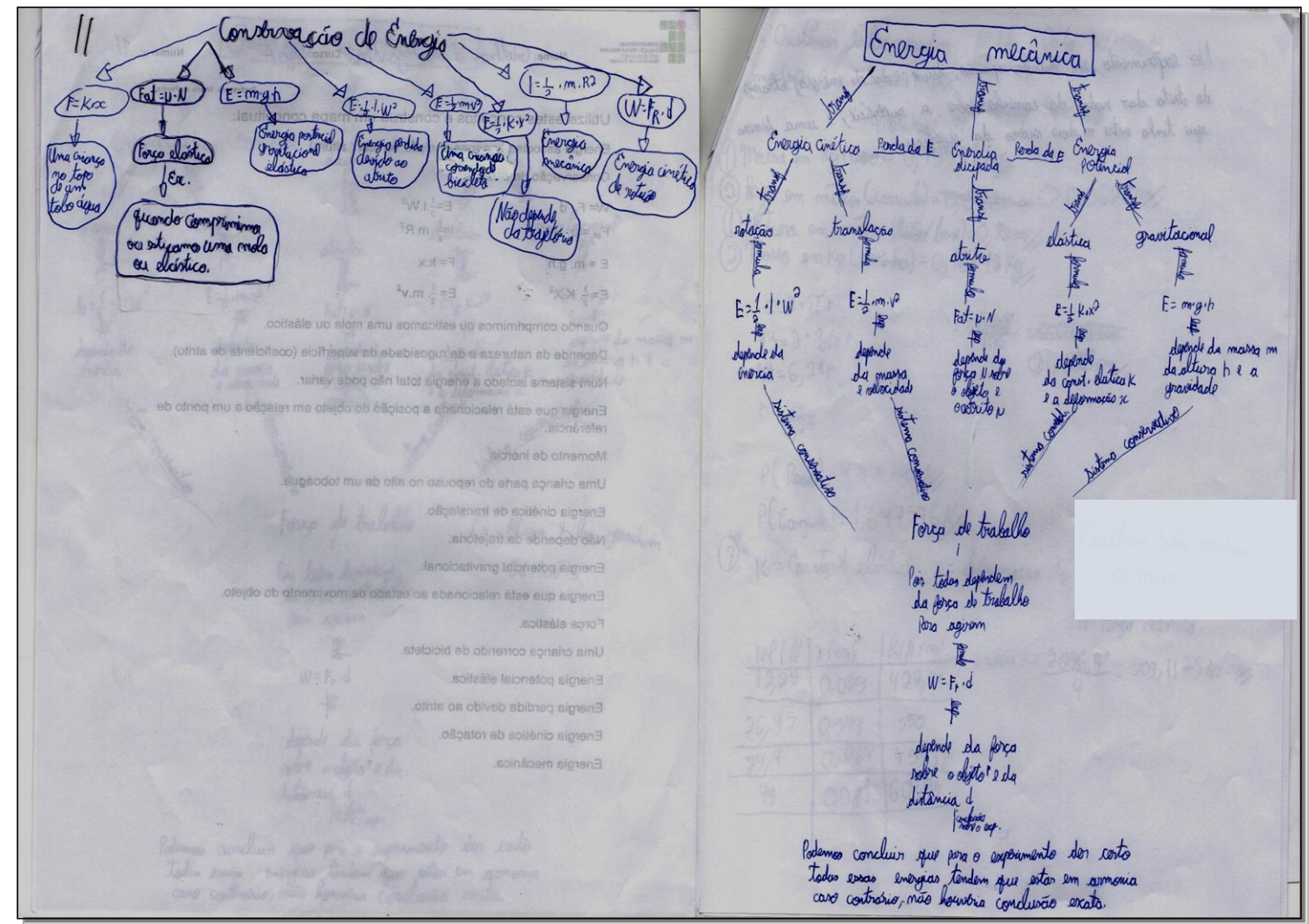

Figura 25: mapas conceituais produzidos pelos alunos. À direita: pós-teste. À esquerda: pré-teste. 


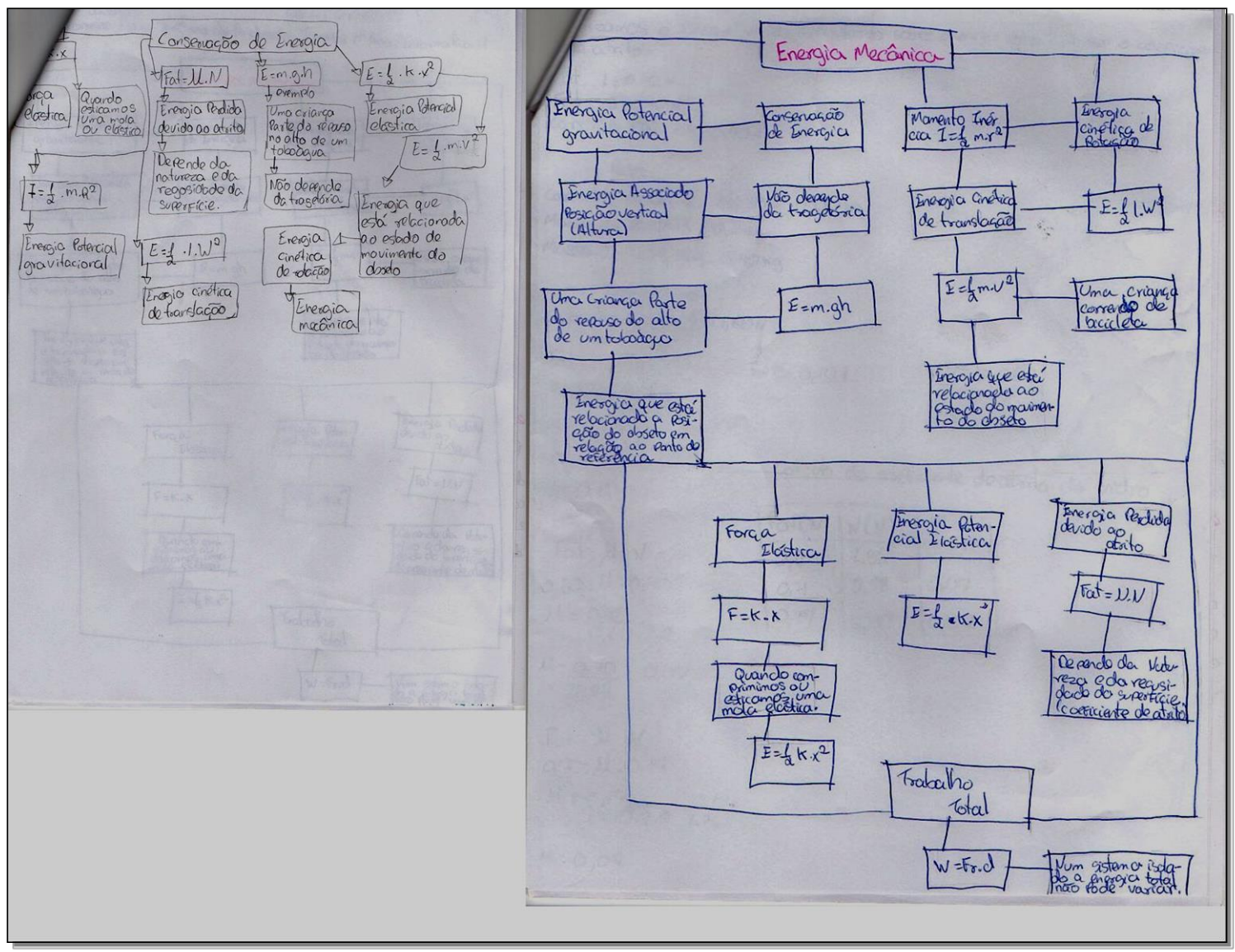

Figura 26: mapas conceituais produzidos pelos alunos. À direita: pós-teste. À esquerda: pré-teste. 
Questionário de avaliação de receptividade destinado aos alunos que participaram do evento educativo.

1 - O arranjo experimental utilizado durante as aulas foi importante para você entender a relação entre as transformações de energia, dissipação e trabalho.

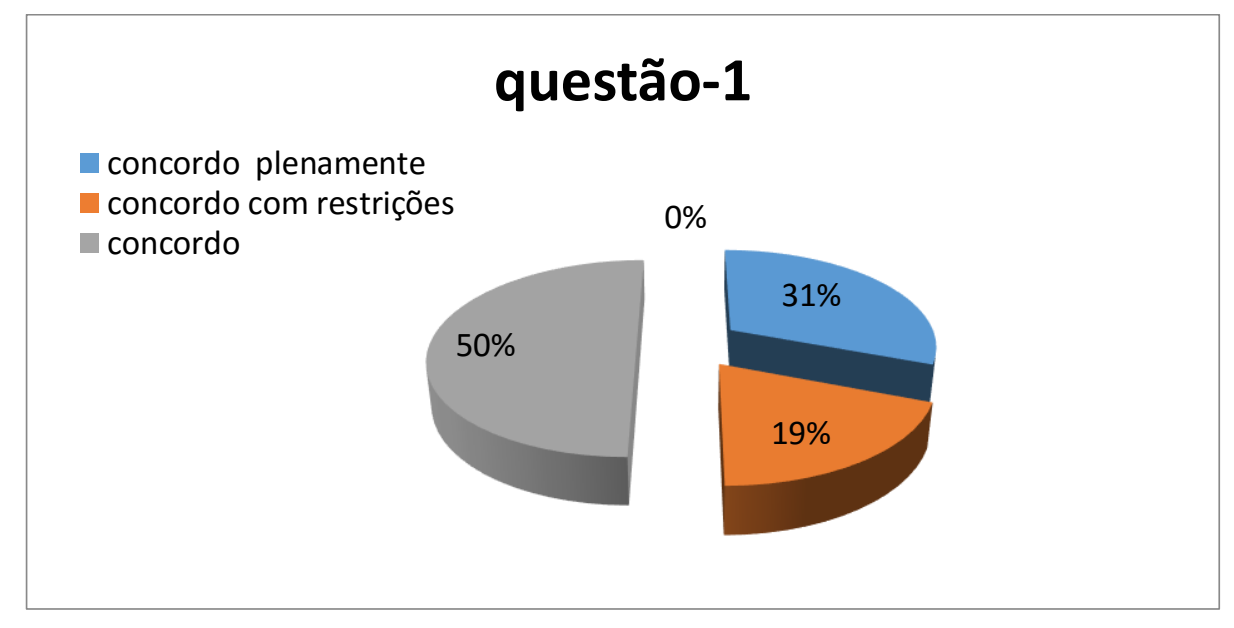
a) concordo plenamente.
b) discordo.
c) concordo com restrições.
d) discordo plenamente.
e) concordo.

2- Você classifica o método utilizado pela professora para abordar este conteúdo em:

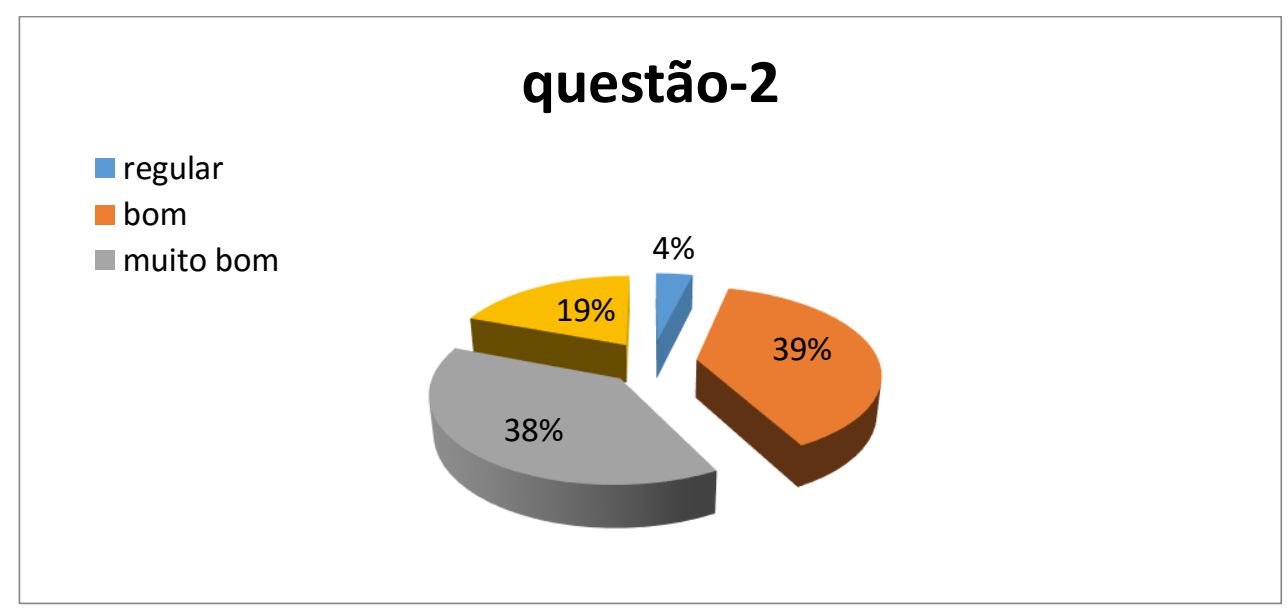
a) péssimo.
b) regular.
c) bom.
d) muito bom.
e) excelente. 
3- Classifique de 1 a 4, segundo o grau crescente de importância, o que foi mais útil para você durante o processo de desenvolvimento das aulas.

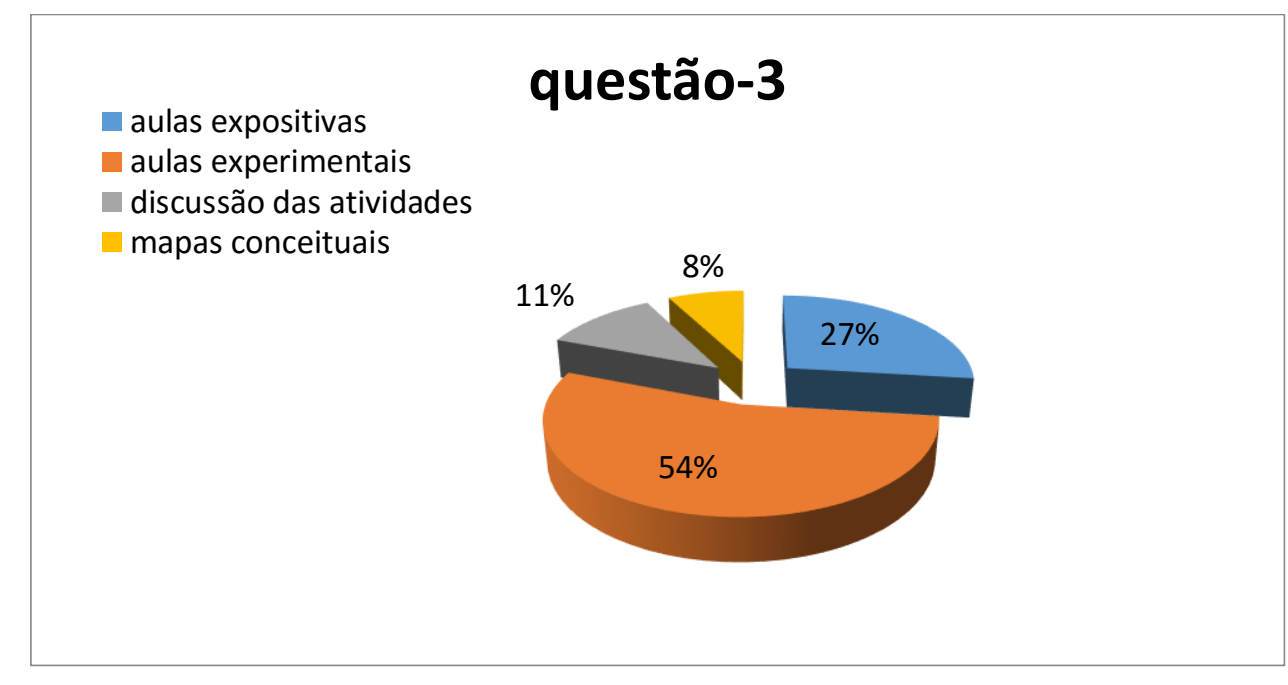

( ) as aulas expositivas do professor na sala de aula.

( ) as aulas de manipulação do aparato experimental e as medidas feitas.

( ) as aulas onde foram discutidos e analisados os resultados observados.

( ) as aulas onde foram construídos os mapas conceituais.

4 - Os conceitos abordados (conservação, dissipação, transformação de energia e trabalho) são importantes para a minha vida.

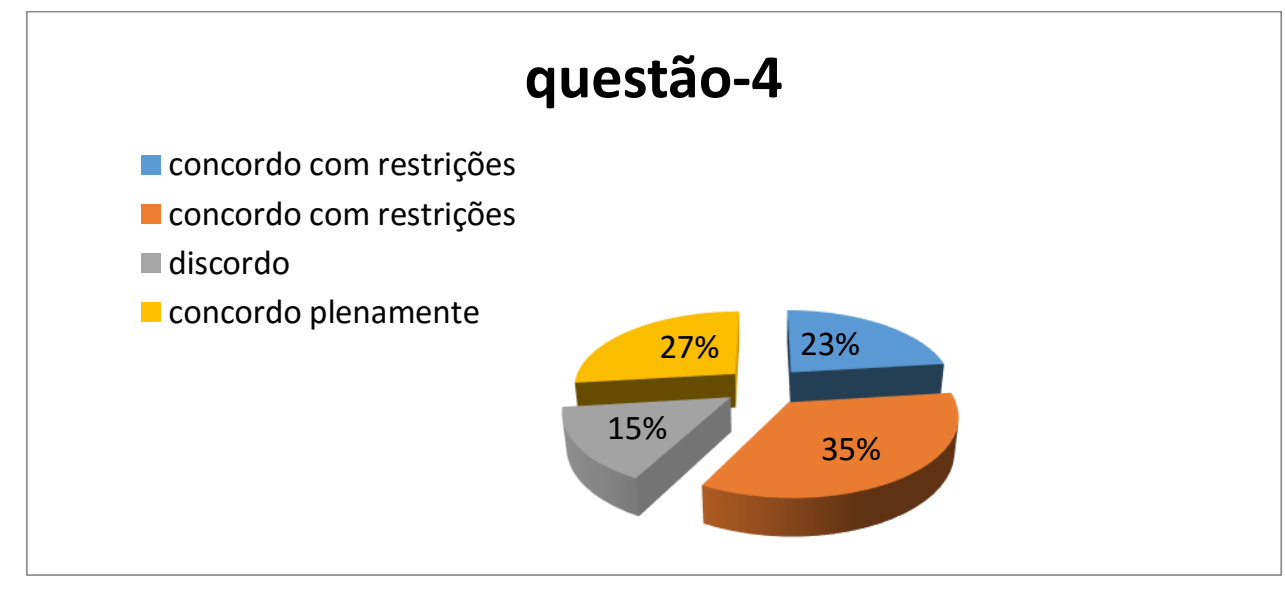
a) discordo plenamente.
b) concordo com restrições.
c) concordo plenamente.
d) concordo.
e) discordo. 
5- Acredito que, se as aulas de física utilizassem mais experimentos onde os alunos pudessem manusear o aparato, fazer medidas, construir tabelas e gráficos, o ensino/aprendizagem da física se tornaria mais fácil e interessante.

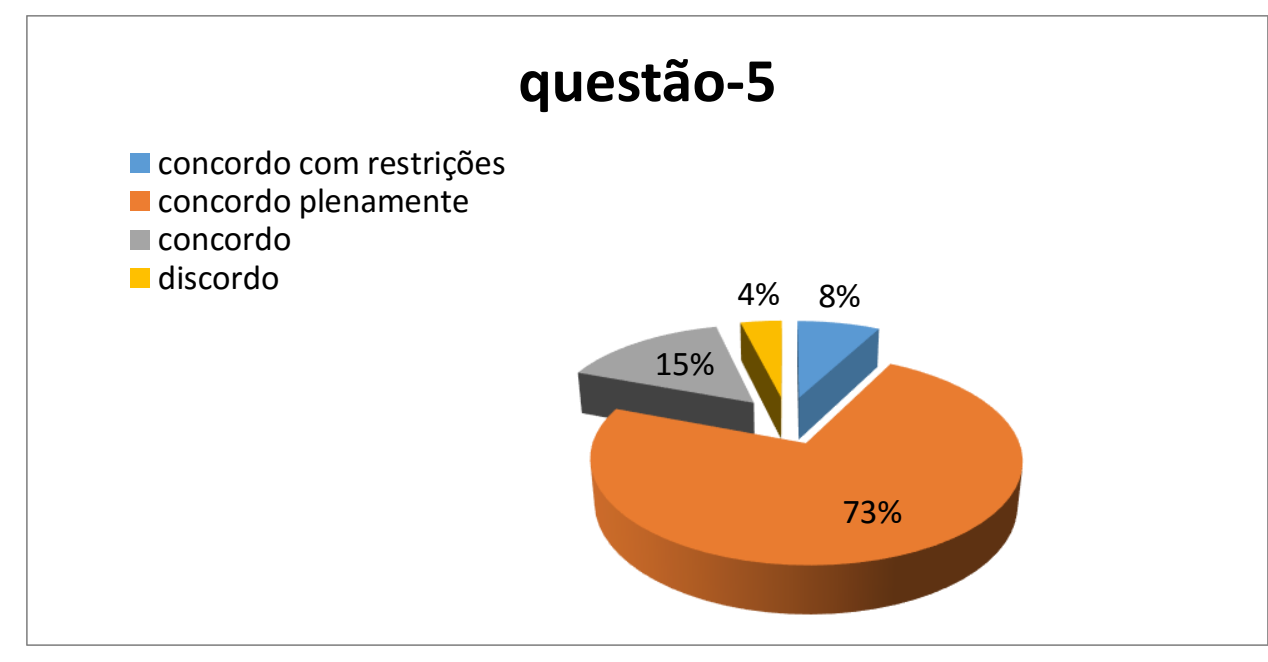
a) concordo plenamente.
b) discordo.
c) concordo com restrições.
d) discordo plenamente.
e) concordo.

6- Acredito que aprendo mais física quando os conteúdos são ensinados com ajuda de experimentos e discussões em grupos. Dessa maneira, fica mais fácil entender a relação entre as expressões matemáticas e os conceitos físicos.

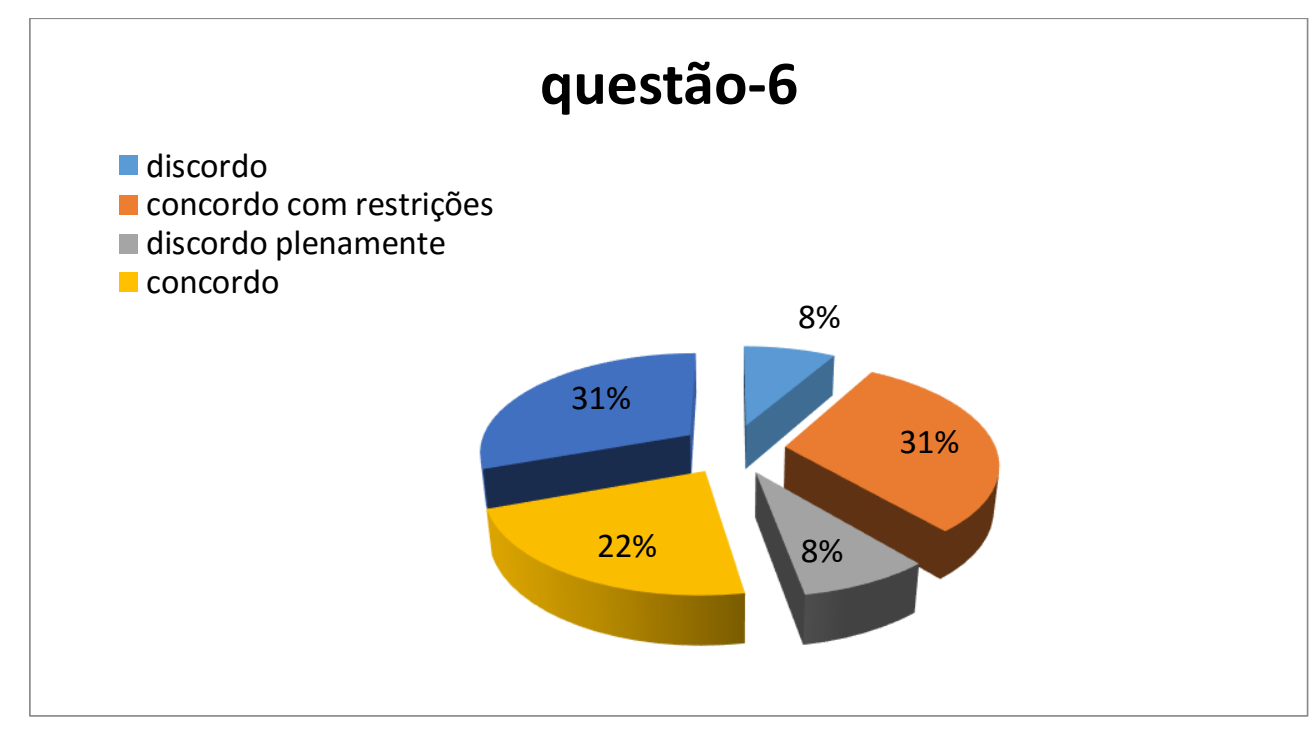



a) discordo.
b) concordo com restrições.
c) discordo plenamente.
d) concordo.
e) concordo plenamente.

7-Dê sua opinião sobre as aulas ministradas com o aparato experimental.

Respostas:

- Física é uma matéria difícil, em minha opinião, com experimentos e trabalho em grupo fica mais fácil.

- O aparato ajudou a maioria dos alunos a entender a matéria, acho que esse tipo de aula é bem interessante.

- O uso do aparato foi de grande ajuda, tanto para entendermos a matéria, quanto para estimular o aluno a se interessar por física.

- A aula ficou mais dinâmica e os alunos demonstraram mais interesse.

- Achei as aulas interessantes e mais intuitivas, mas prefiro aprender à moda antiga.

- Gostei bastante de realizar os experimentos, só que envolvia muito conceitos que ainda não sabia, acho que deveria ter sido mais aula. Mas eu gostei bastante da ideia deste tipo de aula com experimento, pois fica mais atrativo.

- Com o experimento, conseguimos entender boa parte do conteúdo, e com as discussões em grupo com os colegas discutimos nossas duvidas e foi muito bom, conseguimos aprender bastante e com o mapa foi possível fixar o que aprendemos durante as aulas.

- A aula foi muito interessante.

- As aulas foram ótimas, pois nunca teve aula desta maneira.

- As aulas foram muito bem apresentadas e foi muito útil, pois aprendi muito sobre energia e presenciei as transformações na pratica. 
- Vou utilizar este experimento para lembrar o conteúdo quando precisar resolver atividades que envolvam estes assuntos.

- Com o experimento ficou mais fácil aprender diferenciar os tipos de energia e as transformações realizadas e os mapas conceituais ajudou a organizar o que aprendemos.

- Gostei muito das discussões no momento do experimento.

- Foi muito interessante observar a trajetória do carrinho e depois calcular o trabalho a partir dela e considerar a força de atrito para entender os resultados.

- Foi muito interessante, a aula foi diferente das do dia a dia e ajudou a compreender mais a matéria.

- Aulas deste tipo são muito interessantes e ajuda a despertar a curiosidade dos alunos.

- As aulas foram muito interessantes.

- Gostei de fazer os mapas conceituais, no primeiro não sabia quase nada e no segundo foi fácil, pois tinha muita coisa para colocar no mapa.

Obrigada pela participação. 


\section{Capítulo 7}

\section{CONSIDERAÇÕES FINAIS.}

Nesse trabalho, apresentamos o desenvolvimento e a construção de um aparato experimental e de uma sequência de aprendizagem para realizar um estudo do conceito de energia e de suas transformações, utilizando o movimento de deslizamento de um carrinho sobre uma superfície com atrito.

Nossa hipótese de fundo é a de que a utilização de situações experimentais proporciona um ambiente didático mais efetivo e propício para que os alunos adquiram, de forma mais harmônica e integrada, domínio das partes qualitativa e quantitativa dos conceitos físicos. Isso é, em última instância, o que se quer dizer com aprender o conceito significativamente. Com base nessa ideia, acreditamos que não se deve ensinar os conceitos da física sem tentar realizar a conexão íntima entre a intuição fenomênica e o formalismo que fundamenta matematicamente os conceitos. Portanto, partimos da suposição de que a maneira mais fácil e eficiente de efetuar essa conexão seja concentrar-se no papel que a matemática desempenha não exatamente como estruturante das teorias físicas - já descartada a hipótese de apelar para seu papel puramente instrumental -, mas sim no seu papel operacional, dentro de contextos experimentais. Ou seja, na interpretação dos procedimentos de medida das grandezas físicas e na descrição das relações de equivalência entre elas.

Com relação aos aspectos mais gerais envolvendo a aprendizagem de ciência e o ensino de sua natureza e objetivos, temos, no conteúdo específico que abordamos, um ponto chave a ser destacado. Ele diz respeito à diferença que existe entre as construções teóricas e suas aplicações práticas. Isso fica bem ilustrado na tentativa de aplicação do princípio de conservação de energia mecânica. É bastante provável que, nas exposições didáticas teóricas tradicionais, o estudante fique com a impressão de que o princípio é verificado, na prática, sem muitas qualificações adicionais, já que as idealizações que são normalmente feitas não são foco de muita atenção.

De fato, no contexto de aplicação de nosso produto, a ausência de perdas de energia útil através de fricção ou pela movimentação de outras partes do 
sistema, somada ao princípio de conservação da energia mecânica, implicaria que o trabalho total realizado pelas forças de atrito da superfície sobre o carrinho deveria ser igual à energia mecânica inicialmente estocada na configuração. Contudo, o que mais se observa é que, em elevado grau, essa igualdade é violada. Evidentemente, não é o caso de se veicular, para os alunos, a ideia equivocada de que o princípio de conservação da energia não é verdadeiro, nem problematizar o exato caráter epistemológico desse princípio. Deve-se, contudo, levá-los a perceber que a diferença observada deve corresponder, necessariamente, à energia perdida na forma de calor, depois que todo o sistema entra em repouso. E que as forças de atrito presentes entre as partes móveis do sistema, assim como as energias cinéticas adquiridas por elas, fazem parte do conjunto das condições que não estão sendo consideradas nos modelos idealizados. Esse ponto pode e deve ser explorado didaticamente. A partir dele, os estudantes podem começar a perceber que a física (e a ciência, em geral) está envolvida com a obtenção de leis gerais que devem ser exatamente obedecidas em casos ideais cuja possibilidade de verificação está condicionada ao grau de controle que se pode ter de certas condições (reguladas por parâmetros externos) que, contudo, não são levadas em consideração por essas leis.

Em resumo, o que quisemos demonstrar é que a utilização de situações fisicamente concretas de modelos teóricos tem capacidade para propiciar essa interação mais harmoniosa entre as partes qualitativa e quantitativa dos conceitos de maneira mais significativa (e prazerosa), aproximando os conceitos físicos das experiências quotidianas dos alunos. E que tem a capacidade para ilustrar o poder e, ao mesmo tempo, as limitações das leis gerais da física, quando aplicadas a situações reais.

Parte fundamental da estratégia utilizada para o desenvolvimento da sequência didática proposta é baseada na ideia de que a manipulação direta, pelos alunos, do aparato experimental, é absolutamente necessária para suprir as condições acima mencionadas. A esse respeito, o produto educacional desenvolvido procurou fazer com que os estudantes fossem capazes de praticar a identificação, a medição e a conceitualização das grandezas físicas relevantes (energia, trabalho, força), com vistas a alcançar suas definições formais, 
relacionar essas grandezas físicas entre si - constituindo tais relações em termos de leis e princípios gerais (transformação, conservação e dissipação de energia) - e, por fim, analisar, resolver e interpretar problemas envolvendo esses princípios.

Ainda com relação à sequência de aprendizagem proposta, já dissemos que é parte crucial da filosofia desse trabalho a ideia de que os conceitos da física são melhor apresentados quando os seus aspectos quantitativos e qualitativos, experimentais e teóricos são abordados e trabalhados em uma estrutura integrada. Para isso, recomendamos o uso de uma estratégia de ensino "pendular", segundo a qual oscila-se entre uma abordagem mais qualitativa e uma mais quantitativa, tantas vezes quanto necessário para que o aprendizado ocorra.

O produto educacional foi aplicado no Instituto Federal Norte de Minas Gerais - Campus Salinas, para uma turma do primeiro ano do Ensino Médio. Todas as atividades tiveram bom andamento, pois, ao longo de cada uma delas, todos os integrantes da turma participavam ativamente das discussões sobre os resultados encontrados e as estratégias utilizadas para realizar as várias tarefas propostas. De fato, os questionários de avaliação mostraram que quase todos os estudantes apresentaram excelente receptividade à nova abordagem experimental/teórica, que os permitiu visualizar com mais clareza as possíveis ligações entre os conceitos novos a serem aprendidos e seus conhecimentos quotidianos. Uma demonstração positiva com respeito a esse ponto foi o relato dos estudantes de que eles se recordariam do experimento e das vivências de sua aplicação se tivessem que reutilizar os conceitos que foram estudados. Portanto, há um bom indício de que o produto educacional cumpre requisitos para ser considerado potencialmente significativo.

Quanto à avaliação de aprendizagem, empregamos, pela primeira vez, mapas conceituais. Eles se revelaram bons instrumentos e os alunos alcançaram desempenhos razoáveis na sua confecção. Assim, temos também algum indício de que o evento educativo proporcionou aprendizagem significativa. 
O desenvolvimento do trabalho superou minhas expectativas. Pude constatar, através de observações durante a aplicação, que este tipo de metodologia, na qual o conteúdo passa a ser analisado dentro de um método experimental, estimula os alunos a buscar estratégias diferentes para resolver problemas científicos. Os alunos passam a analisar criticamente os resultados e construir explicações para justificar as diferenças existentes entre o que observou experimentalmente e os resultados encontrados com o uso de expressões matemáticas.

Por fim, durante a elaboração e a aplicação desse trabalho, tive eu mesma, a oportunidade de aprender muito. Posso afirmar que essa experiência provocou uma mudança irreversível na minha postura diante do uso de procedimentos experimentais, pois ficou evidente que, com um aparato experimental simples, é possível mobilizar a atividade do aprendiz, em lugar de contar apenas com sua passividade. Acredito que, com esse trabalho, consegui criar condições que propiciaram uma aproximação entre as aulas experimentais e as teóricas, desafiando os estudantes a explorar, desenvolver e avaliar as suas próprias ideias, permitindo uma discussão aberta das limitações que permearam cada atividade proposta. 


\section{REFERÊNCIAS BIBLIOGRÁFICAS.}

ARQUIVO DO IFNMG < http://www.ifnmg.edu.br/salinas/localizacao>acesso dia 26/08/2015.

AUSUBEL, D. P. Aquisição e retenção de conhecimentos: uma perspectiva cognitiva. Lisboa: Plátano Edições Técnicas, v. 1, 2000.

AZEVEDO, H. L. et al . O uso do experimento no ensino da física: tendências a partir do levantamento dos artigos em periódicos da área no Brasil. VII Encontro Nacional de Pesquisa em Educação em Ciências, 2009.

BAPTISTA, J. P. Os principios fundamentais ao longo da História da Fisica. Revista Brasileira de Ensino de Fısica, v. 28, n. 4, p. 541-553, 2006.

BORGES, A. T. Novos rumos para o laboratório escolar de ciências. Caderno Brasileiro de Ensino de Física, v. 19, n. 3, p. 291-313, 2002.

BRASIL. Ministério da educação, parâmetros curriculares nacionais - Ensino Médio. Áreas de linguagens, códigos e suas tecnologias. Brasília: Secretaria de Educação Média e tecnologia/ MEC, 2000.

DE ARAÚJO, M. S. T.; DOS SANTOS ABIB, M. L. V. Atividades experimentais no ensino de fisica: diferentes enfoques, diferentes finalidades. Revista Brasileira de Ensino de Fısica, v. 25, n. 2, 2003.

DE MELLO ARRUDA, S. Metáforas na física. Caderno Brasileiro de Ensino de Física, v. 10, n. 1, p. 25-37, 1993. 
DOS SANTOS, A. B. et al. Energia e suas transformações: uma discussão utilizando um experimento atrativo. Trabalho Completo apresentado no XVII Simpósio Nacional de Ensino de Física - SNEF, 2007.

DRIVER, R. Psicologia cognoscitiva y esquemas conceptuales de los alumnos. Enseñanza de las Ciencias, 6(3), 291-296, 1988.

DUGAS, R.A. History of mechanics, Dover publications, New York, 1988.

EDUCAÇÃO. <http://g1.globo.com/educacao/noticia/2014/09/precisamos-revero-ensino-medio-diz-ministro-da-educacao-sobre-ideb.html > acesso dia $15 / 04 / 2015$.

GINGRAS, Y. What did mathematics do to physics? History of Science, 39, 383-416, 2001.

GOLDSTEIN, H., POOLE, C., SAFKO, J. Classical Mechanics. 3o ed. USA: Addison-Wesley, 2002.

GREF - Grupo de Reelaboração do Ensino de Física. Leituras de Física Mecânica - Instituto de Física da USP, 1998.

HEWITT, P. G. Conceptual Physics. 11ํed. USA: Addison-Wesley, 2010.

JAMMER, M. Concepts of force: A study in the foundations of dynamics, New York: Dover, 1999.

JAMMER, M. Concepts of mass in classical and modern physics, New York: Dover, 1997. 
KAWAMURA, M. R. D.; HOSOUME, Y. A contribuição da Física para um novo Ensino Médio. Física na Escola, v. 4, n. 2, p. 22-27, 2003.

MALVERN, D. Mathematical models in science. In: (Ed.). Developing Models in Science Education: Springer, 2000.

MOREIRA, M. A., Teorias de Aprendizagem. São Paulo: 2. ed. ampliada EPU, 1999.

MOREIRA, M. A., Mapas Conceituais e Diagramas V. Série Textos de Apoio ao Professor de Física, oㅡ 3. Porto Alegre: Ed. do Autor, 2006.

MOREIRA, M. A. O que é afinal aprendizagem significativa?(after all, what is meaningful learning?). Aprendizagem significativa, organizadores prévios, mapas conceituais, diagramas $v$ e unidades de ensino potencialmente significativas, 2012.

MILLAR, R. A means to an end: The role of processes in science education. Practical science, p. 43-52, 1991.

NOVAK, J. e GOWIN, D. Aprender a aprender (C. Valadares, Trad.). Lisboa: Plátano Editora, 1984.

PIETROCOLA, M. Mathematics as structural language of physical thought. Connecting research in physics education with teacher education, v. 2 , 2008. 
PIETROCOLA, M. A matemática como estruturante do conhecimento físico. Caderno Catarinense de Ensino de Física, v.19, n.1: p.89-109, ago. 2002.

POLITO, A. M. M., POLITO, C. M. M. A natureza do espaço em Leibniz e a Correspondência Leibniz-Clarke. Principia, 2015.

PURRINGTON, R. D. Physics in the Nineteenth Century. Rutgers University Press, New Jersey, 1997.

REALE, G, ANTISERI, D. História da Filosofia, vol. 1, Ed. Paulus, São Paulo, 1990.

SÉRÉ, M.-G.; COELHO, S. M.; NUNES, A. D. O papel da experimentação no ensino da física. Caderno Brasileiro de Ensino de Física, v. 20, n. 1, p. 30-42, 2003.

SOLBES, J., TARÍN, F. La conservación de la energía: un princípio de toda la física. Una propuesta y unos resultados. Ensenãnza de las Ciencias, v.22, n.2, p.185-194, 2004.

TAMIR, P. Practical work in school science: an analysis of current practice. Practical science, p. 13-20, 1991.

TOKARNIA, M. http://www.ebc.com.br/educacao/2013/05/mec-quer-programapara-aprimorar-ensino-medio-diz-mercadante acesso dia 24/10/2015. 
THOMPSON, P. W.; THOMPSON, A. G. Talking about rates conceptually, Part I: A teacher's struggle. Journal for Research in Mathematics Education, $p$. 279-303, 1994.

WESTFALL, R.S. The Construction of Modern Science, Mechanisms and Mechanics. Cambridge University press, Cambridge, 1977.

WIGNER, E. P. The unreasonable effectiveness of mathematics in the natural sciences. Richard Courant lecture in mathematical sciences delivered at New York University, May 11, 1959. Communications on pure and applied mathematics, v. 13, n. 1, p. 1-14, 1960.

WHITE, R. F. The link between the laboratory and learning. International Journal of Science Education, v.18, n. 7, p.761-774, 1996.

YEATTS, F. R.; HUNDHAUSEN, J. R. Calculus and physics: Challenges at the interface. American Journal of Physics, v. 60, n. 8, p. 716-721, 1992.

ZAHAR, E. Einstein, Meyerson and the role of mathematics in physical discovery. British Journal for the Philosophy of Science, p. 1- 43, 1980.

ZIBAS, D. M. Escola pública versus escola privada: o fim da história? Cadernos de Pesquisa, n. 100, p. 57-77, 2013. 


\section{APÊNDICE A \\ PRODUTO EDUCACIONAL}

Essa apresentação do produto educacional é composta por um manual explicativo detalhado sobre a construção e o funcionamento do aparato experimental e de um manual de aplicação no qual consta uma sequência de aprendizagem sugerida para abordagem dos conteúdos pedagógicos envolvendo energia e suas transformações.

\section{A.1 - Aparato experimental}

\section{A.1.1 - Descrição do funcionamento do aparato.}

A estrutura conceitual que está na base do funcionamento do aparato consiste nos processos de transformação de duas energias potenciais, a saber, gravitacional e elástica- respectivamente estocadas em duas configurações independentes -, em energias cinéticas de rotação e translação, com subsequente dissipação da energia mecânica total por forças de atrito produzidas em uma superfície rugosa. A configuração estática que estoca a energia potencial gravitacional consiste em um peso incialmente mantido a uma certa altura. A configuração estática que estoca a energia potencial elástica consiste, inicialmente, em uma mola comprimida. Essas energias potenciais serão parcialmente e independentemente transferidas para um corpo rígido (carrinho), de modo a imprimir nele um movimento combinado de rotação e translação. Em seguida, o carrinho será liberado para movimentar-se livremente sobre uma superfície rugosa, que dissipará toda a sua energia.

Para implementar esse esquema, construímos um aparato experimental capaz de executar os processos mencionados. O arranjo experimental que foi efetivamente construído consiste das seguintes partes, com suas funções convenientemente descritas. Primeiramente, temos um disco que será acoplado em uma haste vertical (eixo rotor). O disco deverá ser munido de quatro pontos 
de apoio (carrinho), formados por pontas de pincéis (marcadores de quadro) que deverão ser tingidas com diferentes cores antes do ensaio. Dessa forma, ao deslizar sobre uma superfície plana, os pés do carrinho desenharão sua trajetória. A haste vertical (eixo rotor) possui, na sua parte superior, uma polia fixa (carretel), encaixada no eixo, na qual se enrola um fio de náilon (figura A.1). Inicialmente, o fio de náilon encontra-se completamente enrolado na polia. $\mathrm{Na}$ outra ponta do fio, encontra-se um peso, suspenso verticalmente com o auxílio de uma segunda polia, móvel. O disco e a haste adquirem um movimento de rotação conjunto que the é transferido por meio do peso, à medida que ele cai sob ação da gravidade. No final de seu curso, a queda do peso terá transferido (parte de) sua energia potencial para o sistema eixo rotor e disco, numa quantidade que pode ser calculada medindo-se apenas a massa do peso e a altura total percorrida por ele.

$O$ carrinho se solta do eixo rotor, no momento em que o peso atinge o final de seu curso, tendo desenrolado todo o fio do carretel. Depois de soltar-se da haste, o carrinho atinge a superfície rugosa com a maior parte do movimento de rotação que adquiriu com a queda do peso. Ao atingir a superfície, o carrinho encontrar-se-á girando apenas em torno de seu próprio eixo. No exato instante em que atinge a superfície, contudo, ele sofrerá um impacto horizontal, de modo a receber um impulso que, combinado com o movimento de rotação, fará com que deslize sobre a superfície rugosa, ou seja, fazendo com que o carrinho adquira um movimento de translação combinado a uma rotação. $O$ dispositivo que o impulsiona é composto por uma haste metálica, acionada por uma mola comprimida (ferrolho), que transfere parte de sua energia potencial elástica para o carrinho. O carrinho movimenta-se sobre a superfície rugosa, desenhando, com os seus pés tingidos, a trajetória que será analisada, até que toda a energia adquirida a partir do conjunto (peso e ferrolho) seja completamente dissipada (de forma irreversível), perdendo velocidade até parar (figura A.1). A massa e a altura do peso, bem como a posição a partir da qual o ferrolho será disparado, podem variar e devem ser escolhidas de acordo com cada ensaio. 


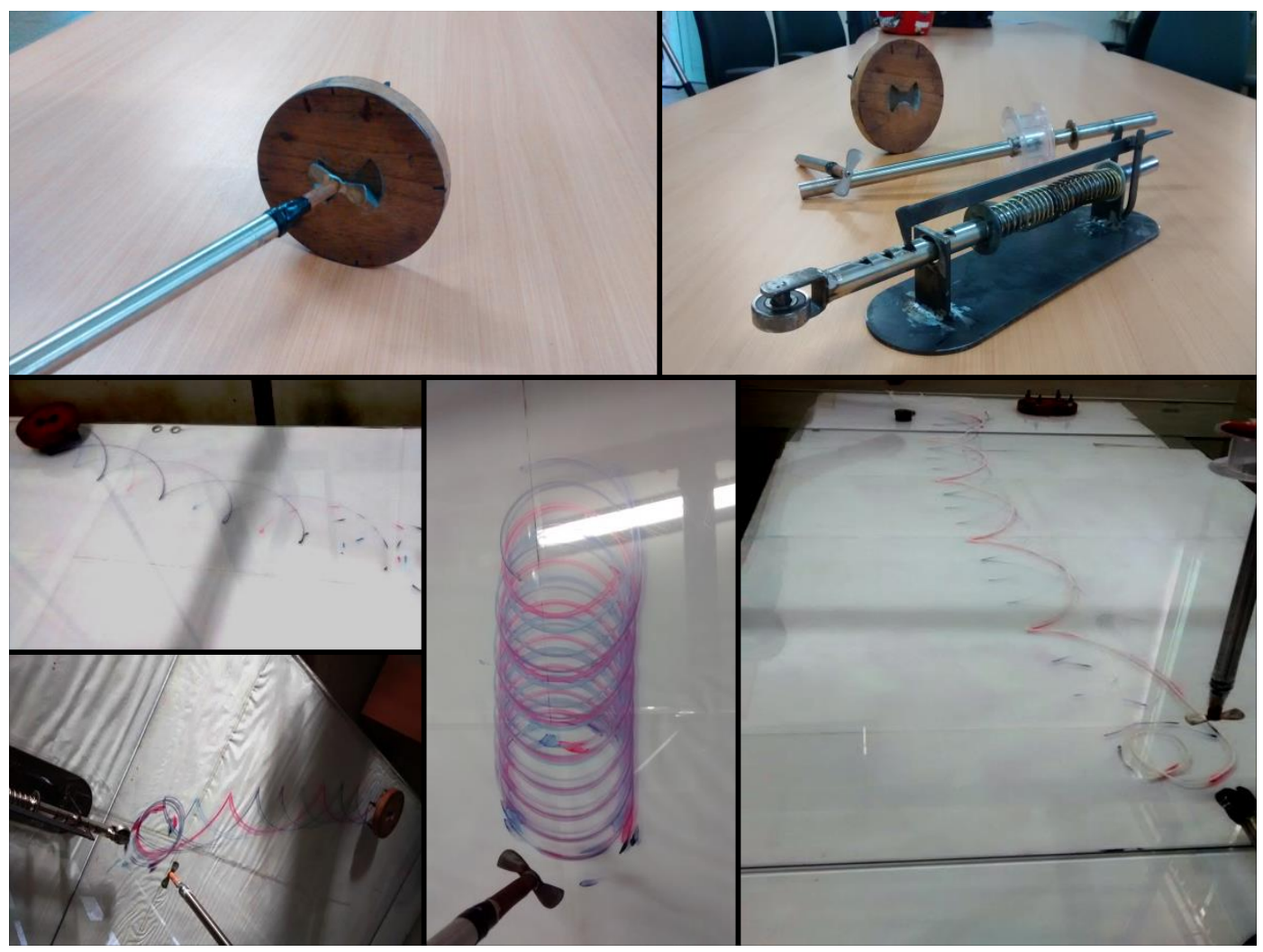

Figura A.1: carrinho, eixo rotor, ferrolho e trajetória traçada pelo carrinho. 


\section{A.1.2 - Descrição dos materiais utilizados.}

Os materiais utilizados para a confecção do aparato experimental foram os seguintes:

- Um cilindro de madeira com quatro pés de apoio (carrinho).

- Uma haste de aço (eixo rotor).

- Um carretel de plástico acrílico (para fixar no eixo rotor).

- Fio de náilon (para conectar o eixo rotor ao peso suspenso).

- Arruelas de ferro de 100 gramas e 200 gramas (para o peso a ser suspenso) e arruela de aço cromado (suspensão).

- Duas polias de ferro (para direcionamento do fio que suspende o peso).

- Tubos e conexões de PVC (para a estrutura de sustentação).

- Mola com uma constante elástica da ordem de $650 \mathrm{~N} / \mathrm{m}$ (parte da estrutura do ferrolho).

- Suporte de madeira e engate de aço.

- Um rolamento (extremidade da haste de impacto do ferrolho).

- Pregos e ferramentas para montagem e fixação.

- Um quadro de vidro (superfície de deslizamento).

- Óleo lubrificante e/ou pó de grafite (lubrificação das partes móveis).

- Folha de isopor.

- Pincéis de quadro branco (para os pés do carrinho).

- Tinta para pincéis de quatro cores diferentes.

- Álcool.

- Ferrolho (dispositivo de travamento e suporte da mola para impacto com o carrinho).

Vamos agora tecer comentários detalhados sobre os materiais utilizados.

a) Cilindro de madeira com quatro pés de apoio (carrinho). $O$ objeto foi feito de madeira. Esse material foi escolhido por ser leve e fácil de ser trabalhado. $O$ formato cilíndrico foi escolhido de modo a que não influenciasse na direção da trajetória descrita, após receber um impacto do ferrolho. Os quatro pés de apoio 
são de madeira e tem um orifício para colocar pontas de pincéis. Coloca-se tintas nestas pontas para marcar a trajetória na superfície deslizante.

b) Haste metálica oca (eixo rotor). A haste foi feita de aço e oca para que ficasse resistente e leve, de modo a que ela gire sem absorver a maior parte da energia potencial do peso suspenso. O eixo rotor deve girar sem travamento dentro do tubo plástico que constitui o suporte horizontal, para diminuir as perdas por atrito. Para isso, deve-se usar lubrificantes. Por outro lado, o eixo rotor deve ficar suficientemente ajustado ao orifício do tubo de sustentação para que sua trepidação natural interfira pouco no movimento rotacional do próprio carrinho.

c) Carretel de plástico. $O$ carretel de plástico, encontrado em lojas de pesca (já vindo com o fio de náilon), foi utilizado por ser leve e possuir um diâmetro adequado para transmitir o movimento para o eixo rotor. Ele deve ficar fixo no eixo rotor.

d) Tubos e conexões de PVC. O suporte de PVC foi utilizado devido às vantagens de acesso, preço e praticidade, pois pode ser montado e desmontado com facilidade.

e) Fio de náilon. Foi escolhido devido sua resistência a choques e por ser bem maleável.

f) Mola de aço. Foi escolhida levando-se em conta sua dureza, para que pudesse proporcionar energia suficiente no impacto com o carrinho e propiciasse o movimento de translação desejado.

g) Arruela de aço. No suporte de PVC será feito um orifício para introduzir o eixo rotor. Para mantê-lo no suporte, sem que deslize e caia, coloca-se a arruela de tal modo que fique presa ao eixo rotor (bastando, para tanto, perfurá-lo de fora a fora e usar essas perfurações como pontos de amarração do eixo à arruela). O conjunto eixo rotor, arruela e carretel estará montado sobre a barra horizontal do suporte (tubo de PVC).

h) Dispositivo de lançamento horizontal do carrinho (ferrolho). Este dispositivo será descrito detalhadamente, mais abaixo, no item d da próxima seção.

i) Superfície deslizante. $O$ vidro foi utilizado para facilitar o deslizamento, devido ao seu relativamente baixo coeficiente de atrito. Uma superfície total de aproximadamente $1 \mathrm{~m}^{2}$ nos foi suficiente, embora isso dependa, em outras 
montagens, da configuração total do aparato. Seu tamanho deve ser, portanto, ajustado em cada caso. Para facilitar a visualização da trajetória, é conveniente colocar papel branco por debaixo do vidro.

\section{A.1.3 - Etapas de confecção e montagem do aparato.}

a) Primeira etapa - confecção do corpo rígido ("carrinho") que será posto para deslizar sobre a superfície com atrito. Esse carrinho pode ser convenientemente confeccionado como um disco de madeira, com quatro pés de apoio. Na parte superior ele deverá ter uma reentrância que servirá para o engate do eixo rotor. Essa reentrância deve ter a sua forma e dimensões ajustadas para que o engate do eixo rotor se dê por simples justaposição. Por isso, deve-se tomar cuidado para que os espaços internos dessa reentrância sejam largos o suficiente para que a aleta de travamento do eixo rotor não fique presa, impedindo que o carrinho se desacople do eixo no momento oportuno (o sistema e o processo de desacoplamento serão descritos abaixo). Na parte inferior do carrinho, serão postos quatro pés de apoio, cada um deles com um orifício. Cada orifício servirá para introduzir pontas de pincéis (marcadores de quadro branco), visando desenhar as trajetórias percorridas pelos pés sobre a superfície de deslizamento. O carrinho que foi efetivamente construído e utilizado possuía as seguintes dimensões: massa de 170 gramas, 2 centímetros de altura, 13,8 centímetros de diâmetro. A posição dos pés, na parte inferior distou 4 centímetros um do outro. Tais medidas não precisam ser necessariamente essas, ficando a critério do experimentador escolhê-las do modo mais conveniente. Contudo, é aconselhável que o carrinho não seja muito mais pesado do que o que utilizamos e nem possua um raio muito maior ou menor, pois isso tudo poderá influenciar no desempenho de seu movimento (figuras A-2).

b) Segunda etapa - confecção de uma haste (eixo rotor) que será posta para girar introduzida verticalmente em um suporte (descrito abaixo) e apoiada por uma arruela. Essa haste deve estar suficientemente livre para girar sem travamento. O eixo rotor foi construído com um tubo oco de aço cromado, possuindo as seguintes dimensões: $42,1 \mathrm{~cm}$ de comprimento, $1,6 \mathrm{~cm}$ de 
diâmetro e $0,15 \mathrm{~cm}$ de espessura. No eixo rotor deve ser colocado um carretel de plástico, fixo. Esse carretel foi fixado no eixo rotor a aproximadamente $14 \mathrm{~cm}$ de sua parte superior, deixando espaço para que o eixo possa ser introduzido no suporte horizontal, com o carretel posicionado por debaixo dele. $O$ carretel que foi utilizado foi possui as seguintes dimensões: diâmetro $62,77 \mathrm{~mm}$, largura 34,95 $\mathrm{mm}$ e peso $36,92 \mathrm{~g}$ (figura A-2). A função desse carretel é permitir que um peso seja conectado ao eixo rotor, por intermédio de um fio de náilon que, ao ser enrolado no carretel, permitirá imprimir a rotação ao sistema composto pelo eixo rotor e pelo carrinho, durante a sua queda. A conexão entre a extremidade inferior do eixo rotor e o carrinho deve ser feita por uma aleta horizontal dupla em forma de borboleta, que se encaixará na reentrância, de formato análogo, construída na parte superior do carrinho. O objetivo é que essa aleta se encaixe de forma justa, mas sem que ela fique travada na reentrância do carrinho. $O$ sistema de desacoplamento consiste no aproveitamento da inércia do próprio carrinho. Ao final do curso vertical do peso, o eixo rotor sofrerá uma brusca parada, mas o carrinho, que, inicialmente, girava impulsionado pelo eixo rotor, tenderá a continuar seu movimento. Isso é suficiente para que a aleta se desconecte da reentrância, permitindo que o carrinho caia. 

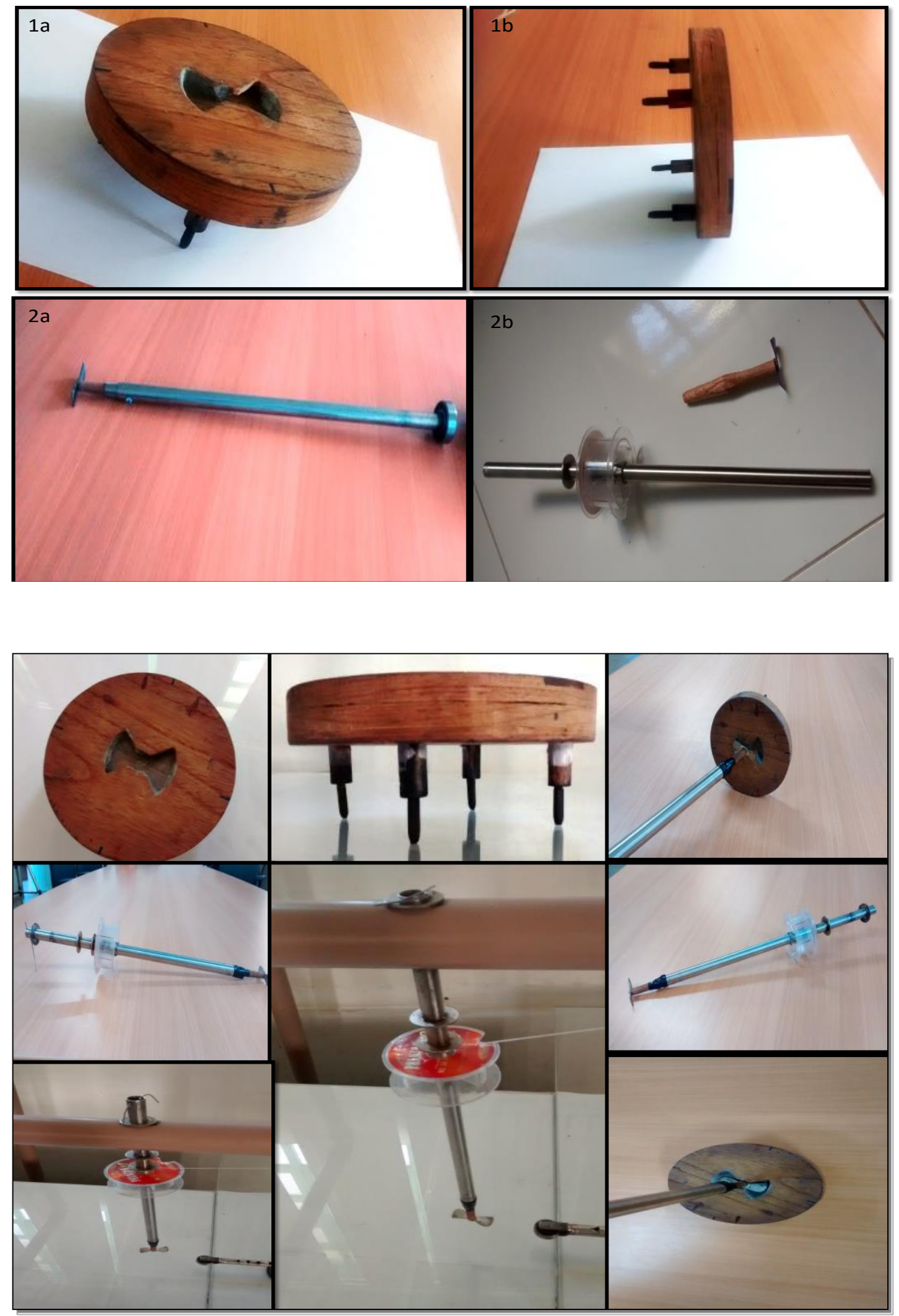

Figuras A-2: partes do aparato experimental: 1-carrinho e 2-eixo rotor. 
c) Terceira etapa - confecção de um suporte para sustentar o eixo rotor. $O$ suporte foi construído como um T horizontal, sustentado por três pés. Isso permite que ele fique por sobre a mesa onde será posta a superfície na qual o carrinho deslizará e na qual também ficará apoiado o ferrolho. Os pés do suporte devem ficar apoiados diretamente no solo. As alturas, tanto do suporte, quanto da mesa, devem ser adaptadas para que a base do disco (corpo do carrinho) fique suficientemente próxima da superfície de deslizamento (mais o menos 5 $\mathrm{cm}$ ), possibilitando um tempo razoável para o mais eficiente acionamento do ferrolho, no momento em que o carrinho atinge a superfície. O material utilizado foram canos e conexões de PVC, de $50 \mathrm{~mm}$, num total de, aproximadamente, 5 $\mathrm{m}$. O suporte completo possuía as seguintes dimensões aproximadas: $1 \mathrm{~m}$ de comprimento, $1 \mathrm{~m}$ de largura e $1 \mathrm{~m}$ de altura. Os objetos que deverão estar fixados na barra central do suporte são o eixo rotor, duas polias e o peso suspenso, nessa ordem. Nessa barra de sustentação horizontal devem ser feitas as devidas perfurações para afixação do eixo rotor e das polias. A perfuração destinada a introduzir e sustentar, verticalmente, o eixo rotor deverá atravessar a barra de sustentação de tal forma que lhe seja possibilitado um giro com o menor grau de travamento possível. É importante, entretanto, que não seja permitida folga excessiva, pois o eixo rotor sofrerá, necessariamente, trepidações causadas por pequenas não-uniformidades na sua distribuição de massa, bem como do próprio carrinho. Uma das polias tem como função apenas servir de guia para o fio de náilon que sai do carretel do eixo rotor e se conecta com o peso. A segunda polia, posicionada exatamente sobre o peso suspenso, tem como função redirecionar a força do peso para promover o giro do eixo, durante sua queda. O fio do náilon deve ser amarrado no carretel sem que permita qualquer escorregamento, ao ter o peso atingido o final de seu curso. Para isso, é suficiente travá-lo em uma ranhura, feita na borda do carretel. Outra preocupação é a de fazer com que o peso suspenso, ao atingir o final de seu curso, atinja algum suporte amortecedor, para evitar que oscile e perturbe 0 movimento do eixo rotor e do carrinho. Esse suporte amortecedor pode ser construído de caixa de papelão e folhas de isopor. O peso efetivamente utilizado foi composto de pilhas de arruelas de ferro de 100 gramas e 200 gramas. Isso permite versatilidade na variação da quantidade de energia transmitida para a 
rotação do carrinho. Evidentemente, fica à critério do experimentador adequar as medidas de acordo com as suas necessidades, de modo que $o$ aparato possa funcionar da melhor maneira possível (figuras A-3 e A-4).

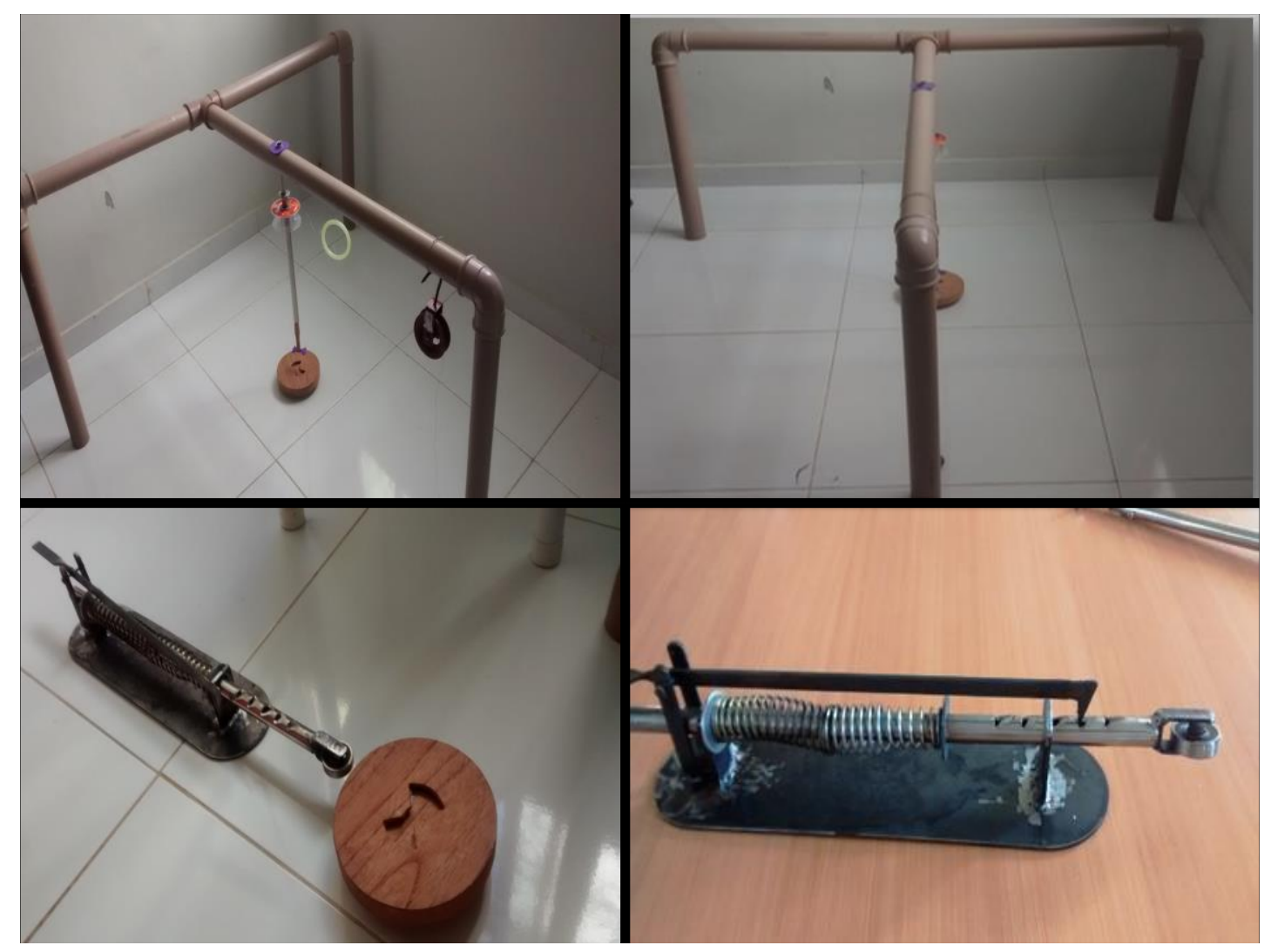

Figura A-3: suporte de PVC e ferrolho. 
d) Quarta etapa - Confecção de um dispositivo de lançamento horizontal para o carrinho (ferrolho). O dispositivo que foi efetivamente construído e utilizado foi feito em uma tornearia. Consiste em um chassi de ferro, no qual são montados uma mola, um dispositivo de trava e uma haste de impacto que, impulsionada pela mola após a operação de destravamento, colidirá com o carrinho, impulsionando-o horizontalmente, sobre a superfície de deslizamento. $O$ dispositivo de trava deve possuir três ou mais pontos de travamento, permitindo alguma versatilidade na escolha de diferentes compressões da mola. A haste metálica de impacto deve possuir um curso livre até o ponto em que a mola atinge o seu comprimento natural. Na extremidade de impacto dessa haste, deve ser colocado um rolimã para que, durante o impacto com o carrinho, sejam minimizadas as perdas por friç̧ão. A mola proverá a energia potencial elástica que deverá ser transmitida ao carrinho, fazendo com que ele adquira um movimento de translação (figuras A-3, A-4 e A-5).

e) Quinta etapa - A superfície escolhida para o carrinho deslizar foi o vidro. Ele foi colocado sobre uma mesa de aproximadamente $1 \mathrm{~m}$ de comprimento e $2 \mathrm{~m}$ de largura. Para facilitar a visualização da trajetória, a mesa foi coberta de papel branco. A superfície por onde o carrinho vai deslizar deve ficar a critério do experimentador, mas é aconselhável que seja uma superfície com baixo atrito e que possibilite a marcação das trajetórias para sua visualização. 


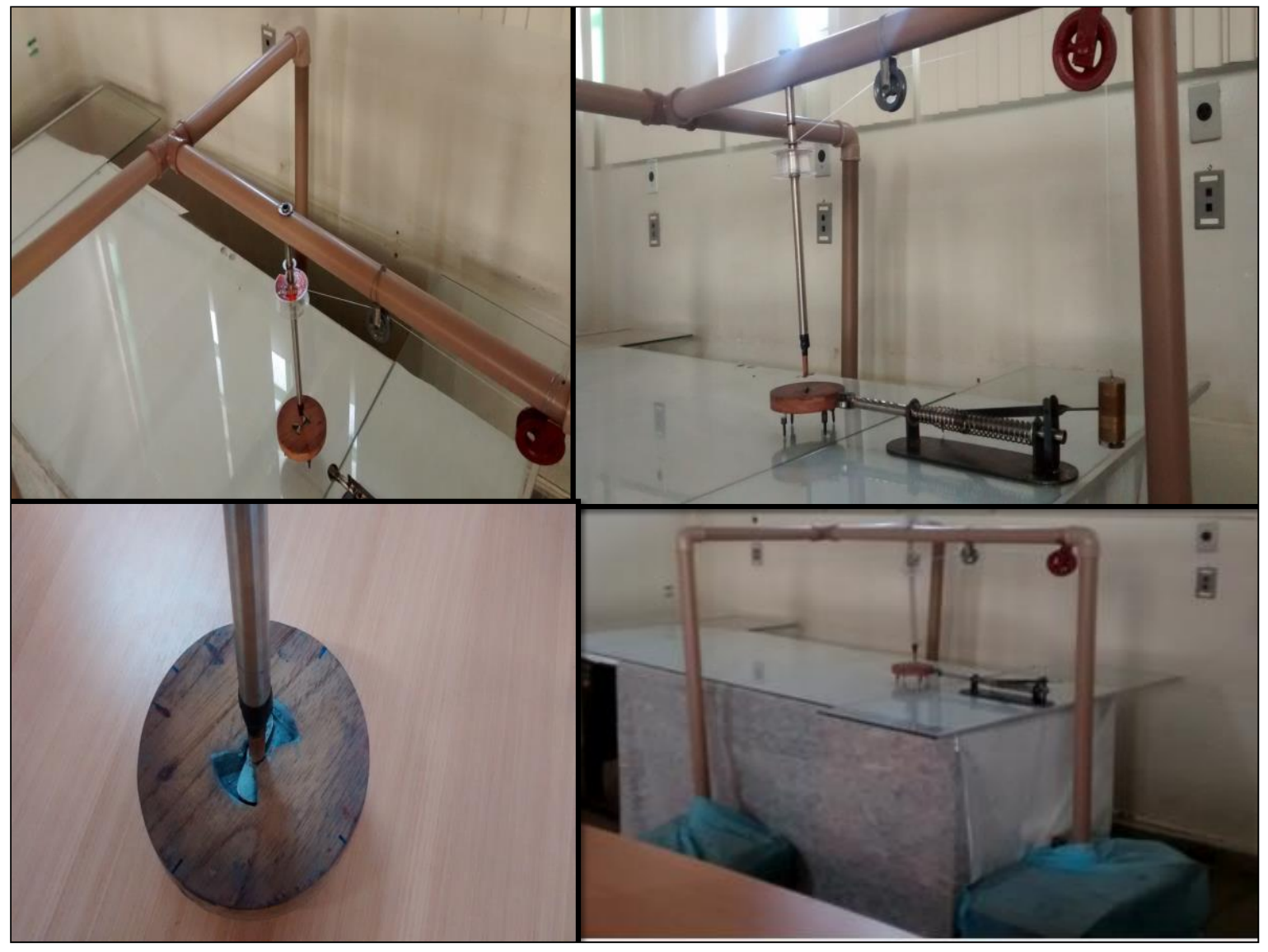

Figura A-4: montagem do aparato 


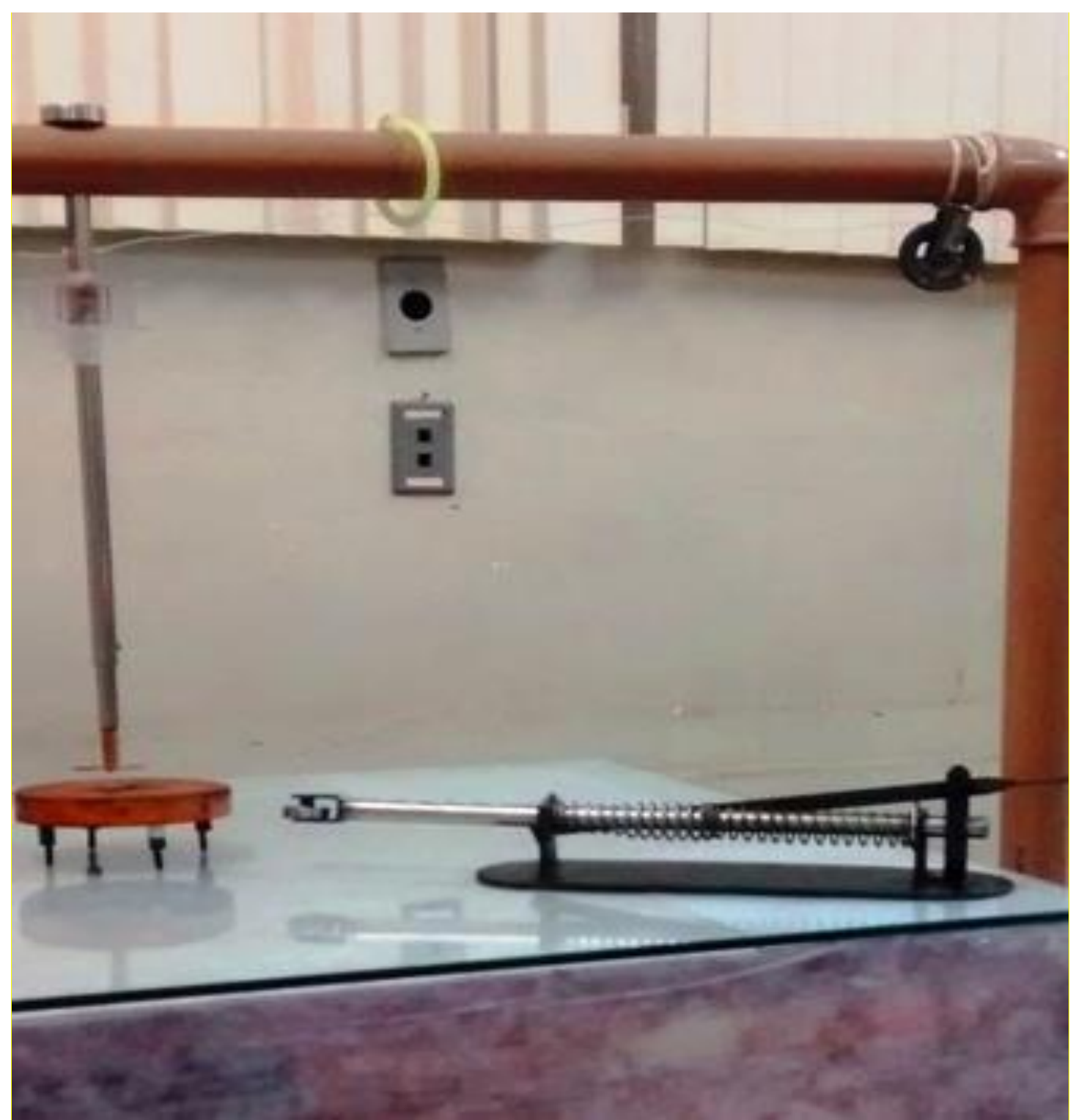

Figura A-5: montagem do aparato 


\section{A.2 - Sequência de Aprendizagem}

Com o uso do aparato experimental, visamos abordar temas relacionados com o ensino do conceito de energia e suas transformações, com enfoque na discussão sobre processos de conservação e de dissipação.

Ao longo da aplicação do produto, fazem-se necessárias diversas estratégias para que esses conteúdos sejam ministrados de maneira a propiciar uma aprendizagem realmente significativa e o que realmente fará a diferença é como este recurso será explorado pelos professores.

Antes de iniciar a sequência, os professores devem fazer os alunos atentarem para os instrumentos de medidas que deverão ser utilizados: uma balança (digital ou analógica), uma régua, uma trena, um ou mais dinamômetros e, eventualmente, um paquímetro. Talvez seja necessário mostrar aos alunos como alguns desses instrumentos funcionam e ensiná-los alguns conceitos básicos de metrologia envolvendo dimensões, unidades, escalas, erros, etc. Dentre esses instrumentos, o dinamômetro e a balança analógica requerem, por sua vez, alguma teoria física que permita a compreensão de seu funcionamento.

Igualmente importantes são equipamentos auxiliares ao uso dos instrumentos e ao trabalho em um laboratório, tais como caderno de anotações, fios e cabos para suspensão, barbante, tinta para os pincéis, álcool para remoção de tintas, etc.

Para a análise quantitativa, faz-se necessário obter algumas quantidades físicas por meio de medidas diretas e obter outras indiretamente por meio de cálculos a partir das suas definições matemáticas. As medidas diretas a serem realizadas para a execução de qualquer ensaio do procedimento são apenas 0 raio e a massa do carrinho. As quantidades físicas a serem obtidas indiretamente, antes da realização de cada ensaio, são o momento de inércia do carrinho, o coeficiente de atrito da superfície de deslizamento, a constante elástica da mola, a energia potencial gravitacional do peso e a energia potencial elástica da mola. As medidas diretas que devem ser realizadas para cada ensaio são a altura do peso em relação à superfície de apoio, a massa do peso, a deformação da mola na posição que foi travada para o ensaio. 
Por fim, uma vez realizado o ensaio, deve-se medir o comprimento da trajetória descrita pelos pés do carrinho em todo seu percurso e o comprimento da trajetória do seu centro de massa, para obter o trabalho total realizado pela força de atrito no processo de dissipação.

A discussão e a análise conceitual, tanto qualitativa quanto quantitativa, serão realizadas após se colocar o aparato em funcionamento e este desenhar uma trajetória sobre a superfície rugosa. Esse desenho pode ser bem variado, a depender dos valores dos parâmetros escolhidos em cada ensaio, mas todas resultam de um acoplamento entre dois movimentos, a saber: um movimento de rotação, que está diretamente relacionado com a energia potencial gravitacional estocada no arranjo, e outro de translação, que está diretamente relacionado a energia potencial elástica estocada no arranjo.

Portanto, a sequência completa de aprendizagem deve ser composta por três etapas: uma etapa pré-experimental, uma etapa experimental e uma etapa de análise do experimento.

\section{A.2.1. Etapa pré-experimental.}

Utiliza-se o aparato para explicar o que se pretende com a sequência. Deve-se expor os objetivos e verificar se os alunos já possuem algum conhecimento prévio sobre o tema. Se necessário, portanto, deve-se fazer uma abordagem teórica que contemple os seguintes temas, ainda que, de início, apenas qualitativamente:

- Energia potencial elástica.

- Energia potencial gravitacional.

- Energia cinética de rotação.

- $\quad$ Energia cinética de translação.

- Momento de inércia.

- Forças de atrito.

- Força elástica da mola.

- $\quad$ Trabalho e teorema do trabalho-energia.

- $\quad$ Princípio de conservação da energia. 
- Dissipação de energia.

O tempo necessário para cumprir essa etapa é variável, mas considerase que duas a três aulas de 50 minutos sejam suficientes.

\section{A.2.2. Etapa experimental}

Para esta etapa o tempo previsto é de aproximadamente quatro aulas de 50 minutos. Nessa etapa, os alunos devem realizar todas as medidas prévias necessárias e realizar um ou mais ensaios com o aparato, anotando, por fim, os resultados. O professor deve atuar como orientador e incentivador para que os trabalhos sejam feitos com o mínimo de percalços.

Se supusermos que as forças de atrito presentes nas diversas partes do arranjo experimental são desprezíveis, o princípio de conservação da energia mecânica implica, necessariamente, que a energia potencial gravitacional estocada no peso suspenso deverá ser convertida em energia cinética de rotação do carrinho, energia cinética de rotação do eixo rotor e polias e energia cinética adquirida pelo próprio peso suspenso, no final de seu curso. Da mesma forma, se supusermos que o choque entre a haste do ferrolho e o carrinho é perfeitamente elástico, a energia potencial elástica estocada na mola deverá ser transformada em energia cinética de translação do carrinho e em energia cinética adquirida pelo pistão do ferrolho e pelo próprio ferrolho, durante o seu recuo. Assim, utilizando as expressões matemáticas adequadas, pode-se calcular a velocidade de rotação inicial, ou seja, a velocidade de rotação que o carrinho possuirá no momento em que é desacoplado. Analogamente, as expressões adequadas nos permitem calcular a velocidade de translação inicial, ou seja, a velocidade de translação que o carrinho possui no momento em que é impulsionado pelo pistão do ferrolho.

$\mathrm{Na}$ verdade, sabemos que todas as suposições acima mencionadas não são verdadeiras. De fato, em primeiro lugar, as forças de atrito presentes entre as partes móveis do arranjo não são desprezíveis. Em segundo lugar, o impacto entre o pistão do ferrolho e o carrinho não é perfeitamente elástico. Esse é um ponto importantíssimo a ser destacado, pois ilustra o grau de afastamento que modelos ideais apresentam com relação ao comportamento real. Isso também 
ilustra o fato de que a maior parte dos avanços tecnológicos modernos envolvidos com o funcionamento de máquinas mecânicas, termodinâmicas e eletromecânicas está relacionada com o esforço de diminuir os efeitos de dissipação. Esse ponto pode e deve ser explorado didaticamente. A partir dele, os estudantes podem começar a perceber que a física (e a ciência, em geral) está envolvida com a obtenção de leis gerais que devem ser obedecidas em casos ideais cuja possibilidade de verificação está condicionada ao grau de controle que se pode ter das condições (reguladas por parâmetros externos) que não são levadas em consideração por essas leis.

A forma correta para se computar o trabalho total efetuado pelas forças de atrito é medir o comprimento da trajetória real em todo o percurso, que é a média dos comprimentos das trajetórias descritas por cada um dos pés do carrinho. (A média aparece quando se soma os trabalhos efetuados sobre cada pé do carrinho, supondo que cada pé sustenta um quarto de seu peso total.) Como dissemos acima, na ausência de deformações e de processos dissipativos nas partes móveis do arranjo, o princípio de conservação da energia mecânica implica que a soma do trabalho total realizado pelas forças de atrito da superfície de deslizamento sobre o carrinho e das energias cinéticas adquiridas pelo peso suspenso, pelo eixo rotor, pelas polias e pelo ferrolho deve ser igual à energia mecânica inicial estocada na configuração do sistema. O objetivo final de toda a análise é verificar em que grau essa igualdade é violada.

Nesse ponto, é interessante realizar uma consideração simplificadora muito útil. Para todos os efeitos práticos e, principalmente, didáticos, o mais importante é analisar todo o aparato como sendo uma máquina cujo objetivo é estocar energia que deverá ser o mais eficientemente possível transferida para o carrinho. Dessa forma, é irrelevante considerar, separadamente, as perdas de energia ocorridas por atrito daquelas ocorridas pela aquisição de energia cinética de todas as demais partes móveis do sistema. Aliás, essas partes móveis também terão, ao fim, suas energias cinéticas dissipadas por forças de fricção, internas ao próprio aparato. Portanto, a diferença entre a energia potencial total estocada e o trabalho executado pelo atrito da superfície deve ser igual à soma de todas as energias dissipadas no arranjo. As forças de atrito presentes entre 
as partes móveis do sistema fazem parte do conjunto das condições que não estão sendo consideradas - e, portanto, não estão sendo controladas - na situação teórica envolvida na validade estrita da conservação da energia mecânica.

Desse modo, é preciso salientar que o modelo teórico é um limite que, embora não possa ser alcançado, pode ser aproximado na medida em que se passe a controlar as condições que não foram consideradas. Isso se traduz, em parte, na eliminação, tanto quanto possível, dessas forças de atrito, por meio de procedimentos de otimização de funcionamento como, por exemplo, lubrificação.

A etapa experimental pode ser dividida em três partes: medidas dos parâmetros do ensaio, ensaio e medida das trajetórias.

\section{a) Primeira parte: medidas dos parâmetros do ensaio.}

Para realizar as medidas diretas das grandezas físicas relevantes podese utilizar apenas os seguintes instrumentos simples: régua, trena, balança e dinamômetro. Dentre as medidas a serem tomadas antes de iniciar qualquer ensaio do experimento, estão as massas do carrinho $\left(\boldsymbol{m}_{c}\right)$ e do peso $\left(\boldsymbol{m}_{p}\right)$ que será suspenso. A massa do peso suspenso pode ser escolhida à vontade. As massas podem ser medidas com o uso da balança ou mesmo do dinamômetro. Da mesma forma, o raio do carrinho $\left(\boldsymbol{R}_{c}\right)$ pode ser medido diretamente com uma régua, ou mesmo utilizando-se a expressão matemática do comprimento da circunferência: $C=2 \pi R$. Deve-se medir também a altura a que peso será suspenso $(\boldsymbol{h})$ com o uso da régua ou de uma trena. Essa altura também pode ser escolhida à vontade.

Antes de cada ensaio, é conveniente já estar de posse dos valores da constante elástica da mola $(k)$ e do coeficiente de atrito estático $(\mu)$ entre 0 carrinho e a superfície de deslizamento.

A constante elástica da mola é o coeficiente de proporcionalidade $k$ na expressão

$$
F=k x
$$


onde $F$ representa o módulo da força a qual está submetida a mola quando comprimida de uma distância $x$. Para obtê-la, é mais conveniente usar um dinamômetro acoplado à mola do ferrolho, comprimindo-a e tomando nota de sua deformação em função da força aplicada. Esse procedimento pode ser executado em algumas posições de deformação diferentes, para aumentar a acurácia da medida, adotando-se uma média aritmética simples como valor final. A ideia por trás desse procedimento pode ser facilmente explicada para os alunos e, em exposições cujo foco é sobretudo os conceitos, e não os procedimentos, quaisquer abordagens estatísticas mais sofisticadas são desnecessárias.

O coeficiente de atrito estático relativo entre a superfície de deslizamento e os pés do carrinho é a constante de proporcionalidade $\mu$ na expressão:

$$
F_{a t}=\mu N,
$$

onde $F_{\text {at }}$ representa o módulo da força de atrito que se opõe ao movimento do carrinho e $N$ representa a força normal, ou seja, o peso do carrinho. À rigor, o coeficiente de atrito que deve ser utilizado é o cinético. Entretanto, devido às maiores dificuldades envolvidas na sua obtenção, pode ser mais conveniente usar o coeficiente de atrito estático, sobretudo quando se constata que outros erros inerentes ao experimento são (possivelmente) bem maiores do que 0 envolvido nessa aproximação. Para calculá-lo, basta usar o dinamômetro acoplado ao carrinho, puxando-o sobre a superfície rugosa até que ele esteja prestes a iniciar o movimento. Nesse instante, toma-se nota do valor da força. É conveniente que esse procedimento seja executado várias vezes, com diferentes pesos sobre o carrinho, para aumentar a acurácia da medida, de modo que o valor a ser adotado seja a média aritmética simples dos vários resultados. Outra maneira interessante de se fazer essa medida é colocar o carrinho sobre a superfície de vidro, mas com inclinação variável. A medida das alturas com as quais o carrinho (com e sem peso) entra em movimento são um indicativo direto, proporcionando, ainda, uma boa justificativa para se revisitar os conceitos de estática e mostrar sua utilidade em outros contextos. 
Daqui em diante, todas as quantidades físicas devem ser obtidas matematicamente, pelo uso de suas expressões. O momento de inércia ( $I$ ) do carrinho deve ser calculado pela expressão

$$
I=\frac{1}{2} m_{c} R_{c}^{2}
$$

Esse é o momento de inércia de um cilindro, calculado em relação ao seu eixo de simetria. O eixo rotor, ao qual o carrinho está acoplado, e as polias também possuem momentos de inércia, que podem ser calculados por uma expressão análoga. Entretanto, em uma abordagem preliminar, pode-se desprezar 0 momento de inércia do eixo rotor, já que é bem menor do que o momento de inércia do carrinho.

A energia potencial gravitacional estocada no peso suspenso é dada por:

$$
E_{\text {potg }}=m_{p} g h
$$

onde $g$ é a aceleração da gravidade local.

A energia potencial elástica estocada na mola é dada por:

$$
E_{p o t k}=\frac{1}{2} k x^{2}
$$

A energia cinética de rotação adquirida pelo carrinho e pelo eixo rotor é dada, em função de seu momento de inércia total, pela expressão:

$$
E_{\text {cinrot }}=\frac{1}{2} I \omega^{2}
$$

onde $\omega$ é a velocidade angular adquirida pelo carrinho, aproximadamente aquela com a qual ele tocará a superfície, após desacoplar-se do eixo rotor. Evidentemente, para se obter essa energia de forma direta (e mais acurada), seria necessário efetuar a medida da velocidade angular diretamente. Essa é uma medida que requereria ou instrumentos e dispositivos mais complicados (e 
caros) ou o uso de aplicativos de computador. Entretanto, como o foco da sequência de aprendizagem está menos voltado para a precisão e mais para os conceitos que estão por trás dos processos de transformação (e dissipação) da energia, optamos por avaliar a energia cinética (e, indiretamente, a própria velocidade angular) através de sua igualdade com a energia potencial gravitacional, conforme descrito mais abaixo.

A energia cinética de translação adquirida pelo carrinho é dada pela expressão:

$$
E_{\text {cintrans }}=\frac{1}{2} m_{c} v^{2},
$$

onde $v$ é a velocidade linear inicial adquirida pelo carrinho. Evidentemente, para se obter essa energia de forma direta (e mais acurada), seria necessário efetuar a medida da velocidade linear diretamente. Da mesma forma que no caso anterior, essa é uma medida que requereria ou instrumentos e dispositivos mais complicados (e caros) ou o uso de aplicativos de computador. E, pelos motivos já expostos, optamos por avaliar a energia cinética (e, indiretamente, a própria velocidade linear) através de sua igualdade com a energia potencial elástica, conforme descrito mais abaixo.

O resumo das atividades dessa primeira parte pode ser observado no guia A-1.

\section{b) Segunda parte: Procedimentos para execução dos ensaios.}

Após todas as medidas feitas, é hora de colocar o aparato para funcionar. Para executar cada ensaio, deve-se escolher o peso que será utilizado e conectá-lo ao fio de náilon. Antes de acoplar o carrinho à extremidade do eixo rotor, é importante nivelar suas pontas de apoio (pontas de pincéis) e colocar tintas com cores diferentes nessas pontas. Em seguida, deve-se enrolar o fio de náilon no carretel até o peso a ser suspenso atingir a altura desejada para 0 ensaio. Nesse momento, deve-se segurar o eixo rotor com uma das mãos e engatar o carrinho. 
A posição na qual ficará fixado o chassi do ferrolho depende da posição na qual cairá o carrinho. Antes de iniciar o ensaio, é conveniente posicionar o tripé sustentador de tal modo que a reta definida pela haste de impacto do ferrolho venha a passar pelo centro geométrico do carrinho, no ponto em que cairá, de modo a conseguir um impacto frontal, ou seja, com parâmetro de impacto zero. Uma segunda pessoa deve estar presente para realizar cada ensaio. Essa segunda pessoa será responsável por travar a mola do ferrolho de acordo com a energia potencial elástica que deseje estocar e transferir para o carrinho no seu movimento horizontal. A mola deverá ser destravada no momento em que o carrinho tocar o solo.

Ao soltar o eixo rotor, o peso suspenso descerá e o conjunto (eixo rotor, carretel e carrinho) vai adquirir um movimento de rotação. No momento em que o peso atingir a superfície de amortecimento, o carrinho se desengatará do eixo rotor e atingirá a superfície de deslizamento, mantendo a maior parte do movimento de rotação que adquiriu por meio da queda do peso. Quando o carrinho atingir a superfície, girando, o ferrolho deverá ser destravado manualmente. Espera-se que haja suficiente sincronia para que o impacto da haste horizontal do ferrolho se dê com o menor atraso possível, evitando que o carrinho gire muito sobre o mesmo ponto. Isso não é exatamente relevante para a análise conceitual, mas trajetórias mais fáceis de serem analisadas serão descritas através desse procedimento.

\section{c) Terceira parte: medidas das trajetórias.}

Após a realização de cada ensaio, quatro trajetórias terão sido desenhadas pelos pés do carrinho na superfície de deslizamento. $O$ trabalho total da força de atrito da superfície deve ser calculado a partir de:

$$
W=F_{a t} d,
$$

onde $d$ é a distância escalar total percorrida pelos pés do carrinho. $O$ carrinho é freado pela ação das forças de atrito sobre cada um dos seus quatro pontos de apoio. Em um carrinho completamente simétrico, cada ponto de apoio sustenta exatamente um quarto do peso do carrinho. Portanto, para obter 0 trabalho total, é necessário computar, separadamente, o comprimento das 
trajetórias desenhadas pelos pés do carrinho, somando-as, ao final. Isso, evidentemente, é equivalente a calcular o trabalho usando a expressão acima com $d$ sendo obtido como a média aritmética desses comprimentos e com a força normal sendo avaliada a partir da massa total do carrinho. Para efetuar a medida do comprimento de cada trajetória, é conveniente usar um cabo flexível (por exemplo, barbante) ao longo do desenho deixado por cada pé, medindo-se, em seguida, o comprimento do cabo.

O resumo das atividades das segunda e terceira partes ser observado no guia A-2.

\section{A.2.3. Etapa de análise do experimento.}

Para essa etapa, prevê-se a utilização de duas aulas de 50 minutos. Em uma situação ideal, pode-se supor que não existem forças dissipativas interferindo no funcionamento do aparato. Desse modo, o princípio de conservação da energia mecânica implicaria que toda a energia potencial estocada na configuração do aparato seria transformada em energia cinética (do carrinho e das partes móveis do aparato alimentadas pela energia potencial gravitacional). O primeiro passo da análise consiste em mostrar que se pode estimar as velocidades iniciais do carrinho com base na aplicação desse princípio.

Nessas condições, toda a energia potencial gravitacional será convertida em energia cinética de rotação, adquirida pelo carrinho, e em energia cinética das partes móveis ( $\left.E_{\text {movPeso }}\right)$ :

$$
E_{\text {potg }}=E_{\text {cinrot }}+E_{\text {movPeso }} \Rightarrow m_{p} g h=\frac{1}{2} I \omega^{2}+E_{\text {movPeso }}
$$

de onde se pode fazer uma estimativa superior da velocidade de rotação do carrinho no momento que ele se solta do eixo rotor e atinge a superfície de deslizamento. Da mesma forma, a energia potencial elástica da mola seria toda convertida em energia cinética de translação, adquirida pelo carrinho logo após 
o impacto efetuado pelo eixo do ferrolho, acrescida da energia cinética fornecida para o próprio ferrolho (EmovMola):

$$
E_{\text {potk }}=E_{\text {cintrans }}+E_{\text {movMola }} \Rightarrow \frac{1}{2} k x^{2}=\frac{1}{2} m_{c} v^{2}+E_{\text {movMola }}
$$

de onde pode-se estimar um limite superior para a velocidade de translação inicial do carrinho.

O segundo passo da análise consiste em analisar a validade do teorema do trabalho-energia. Novamente, se supusermos que as únicas forças que atuam sobre o carrinho são aquelas aplicadas pela superfície rugosa, então toda a energia cinética adquirida pelo carrinho deveria ser dissipada apenas pelo trabalho dessas forças de atrito. Assim, um tratamento idealizado implica que o trabalho calculado deve ser igual à soma das energias cinéticas de rotação e de translação do carrinho:

$$
W=F_{a t} d=\frac{1}{2} I \omega^{2}+\frac{1}{2} m_{c} v^{2}
$$

ou, de forma equivalente, o trabalho calculado deveria ser igual à soma das energias potenciais, descontadas as parcelas de energia fornecidas para 0 movimento do próprio peso suspenso e da mola:

$$
W=F_{a t} d=m_{p} g h+\frac{1}{2} k x^{2}-E_{m o v M o l a}-E_{m o v P e s o}
$$

Sabemos, contudo, que existem forças de atrito agindo entre as partes móveis do aparato, o que significa que a situação real deve ser diferente da situação ideal. É fácil observar que tais forças de atrito são, na sua maior parte, aquelas provenientes, primeiramente, da rotação do eixo rotor contra o orifício da barra horizontal de suporte e, em segundo lugar, da fricção da haste de impacto do ferrolho contra a carcaça metálica que a sustenta. É óbvio que todas essas partes móveis que friccionam dissipam parte da energia potencial, diminuindo a eficiência do dispositivo. Tais perdas podem ser minoradas com o 
uso de lubrificantes e, principalmente, através de soluções mais sofisticadas, mas não podem nunca ser completamente eliminadas.

Uma estimativa das parcelas de energia entregues para os movimentos do próprio peso e do ferrolho ( $E_{\text {movPeso }}+E_{\text {movMola }}$ ) pode ser feita. Porém, como o interesse está em observar o aparato como uma máquina cujo objetivo é fornecer a energia estocada para suprir o movimento do carrinho, essas parcelas podem ser consideradas como parte das perdas internas do próprio dispositivo. Isso, evidentemente, aumenta ainda mais a estimativa de sua ineficiência. Isso, contudo, não é irreal, já que perdas análogas a essas estão envolvidas em quaisquer máquinas que, para funcionar, apresentem partes móveis internas. $\boldsymbol{A}$ estimativa do percentual da energia que é perdida desses modos, ou seja, a estimativa da real eficiência do sistema para converter energia potencial em energia de movimento útil, é o principal objetivo a ser atingido pelo uso dessa montagem experimental. Essa estimativa pode ser dada pela razão:

$$
\eta=\frac{F_{a t} d}{m_{p} g h+\frac{1}{2} k x^{2}}<1
$$

Portanto, os processos dissipativos e de perdas em geral implicam que o trabalho total efetuado pelas forças de atrito devidas apenas à superfície deve ser substancialmente menor do que a energia potencial mecânica total estocada, inicialmente, no aparato. A diferença tem que ser o cômputo da energia que foi dissipada na forma de calor, no próprio aparato, depois que todo o sistema entra em repouso.

Por fim, uma outra análise interessante que também pode ser feita consiste em calcular, separadamente apenas os trabalhos realizados nos movimentos de translação e de rotação do carrinho. No primeiro caso, computase a distância percorrida pelo seu centro de massa. No segundo, o número de voltas que o carrinho efetuou em torno de seu próprio eixo, deduzindo, daí, a distância total percorrida apenas em rotação pura. O trabalho efetuado sobre 0 centro de massa pode ser comparado com a energia cinética de translação ou, equivalentemente, com a energia potencial elástica da mola. Já o trabalho 
efetuado sobre o movimento de rotação pura pode ser comparado com a energia cinética de rotação ou, equivalentemente, com a energia potencial gravitacional do peso. Espera-se que a diferença entre o trabalho total e o trabalho efetuado sobre o centro de massa seja igual ao trabalho efetuado sobre o movimento de rotação. Com essa análise, podemos, inclusive, estimar qual deveria ser a quantidade total de voltas que o carrinho efetuaria em torno de seu próprio eixo. Essas e outras análises, baseadas em medidas e cálculos baseados em expressões matemáticas, demonstram a versatilidade do aparato para a realização de múltiplas atividades didáticas.

O professor pode avaliar o grau de aprendizagem da maneira que mais Ihe convier. Exemplos de questões que podem ser levantadas.

- Os resultados obtidos estão de acordo com as suas expectativas? Por quê?

- O que você esperava obter supondo a validade do princípio de conservação de energia nos processos?

- Onde você acha que poderiam estar acontecendo perdas de energia?

- Você seria capaz de citar alternativas que pudessem melhorar estes resultados? Quais?

- O que você acha dos valores encontrado para as velocidades de rotação e de translação? Elas são compatíveis com os movimentos observados?

O resumo das atividades de análise conceitual pode ser observado no guia A-3. 


\section{Primeira parte do experimento: medidas dos parâmetros do ensaio}

1 - Medir a massa do peso que vai ser suspenso e a altura da qual ele será solto em relação ao ponto de apoio. Medir o raio e a massa do carrinho. Obs: a medida da altura de deslocamento deve ser realizada sempre usando o mesmo ponto de referência no peso.

2 - Medir a constante elástica da mola. Procedimento: engate um dinamômetro na mola do ferrolho e puxe no sentido de contração da mola, registrando a deformação da mola e a força que o dinamômetro marca em cada deslocamento. Façam no mínimo quatro medidas, montem uma tabela e, utilizando a fórmula da força elástica $(F=k . x)$, calcule a constante elástica da mola. Faça uma média aritmética com os resultados e utilize esse valor, quando precisar da constante elástica da mola $(\mathrm{k})$.

3 - Medir o coeficiente de atrito (estático) da superfície por onde o carrinho deslizou. Procedimentos: (i) escolha um peso, coloque sobre o carrinho, engateo no dinamômetro e tente puxar o carrinho sobre a superfície até o momento que você conseguir tirá-lo do lugar, (ii) registre esta força e a massa do peso que foi puxado. Este procedimento deve ser repetido no mínimo quatro vezes com pesos diferentes. Calcule o coeficiente de atrito da superfície utilizando a formula $(\mathrm{F}=\mu . \mathrm{N})$ e monte uma tabela. Faça uma média aritmética com os resultados e utilize esse valor quando precisar do coeficiente de atrito estático da superfície.

\section{Guia A-1}




\section{Segunda e terceira partes do experimento: ensaio e medidas das trajetórias.}

4 - Amarre o peso que deseja levantar no fio, enrole o fio no carretel até que o peso atinja a altura desejada para o ensaio, segure com uma mão o eixo rotor (abaixo do carretel) e engate o carrinho.

5 - Posicione o ferrolho em uma posição que favoreça atingir o carrinho no momento que ele tocar a superfície rugosa, use ventosas para fixá-lo nesta posição e trave a haste do ferrolho, comprimindo a mola na posição desejada para o ensaio.

6 - Solte o eixo rotor. No momento em que o carrinho se soltar e atingir a superfície de deslizamento, acione o ferrolho.

Obs: Para executar o ensaio será necessária a participação de, no mínimo, dois alunos, um para colocar o peso, enrolar o fio no carretel, segurar o eixo rotor, engatar o carrinho e depois soltar o eixo rotor no momento adequado, e outro para posicionar e fixar o ferrolho, travar a haste do ferrolho e desengatá-lo no momento adequado. Este processo de desengate/liberação do ferrolho tem que ser treinado com antecedência para melhorar o tempo de reação de modo que a haste do ferrolho bata no carrinho assim que ele cair sobre a superfície.

7 - Com a trajetória marcada, ligar os quatro pontos de saída deixada pelos pés do carrinho e marcar o centro do carrinho, repetir o mesmo processo nos pontos de chegada. Estime, com o auxílio do desenho marcado na superfície rugosa, quantas voltas o carrinho pode ter executado.

8 - Medir a distância entre o centro do carrinho, no ponto de saída, até o ponto de chegada da trajetória descrita por ele. Essa distância será utilizada para calcular o trabalho da força de atrito do movimento de translação.

9 - Coloque barbante sobre o desenho traçado na superfície rugosa, acompanhando o formato do desenho e meça o comprimento traçado por cada pé separadamente. Calcule a média dessas medidas. Essa distância será utilizada para calcular o trabalho envolvendo o movimento de translação e rotação, ou seja, o trabalho total. 


\section{Análise Conceitual:}

1 - Realize as seguintes tarefas:

a) Calcule a energia potencial gravitacional do peso suspenso.

b) Calcule a energia potencial elástica da mola.

c) Calcule o trabalho da força de atrito no deslizamento do carrinho.

d) Relacione as energias calculadas nos itens a e b com o trabalho calculado.

e) Discuta os resultados com os colegas e anote as possíveis conclusões.

2- Considere, nas tarefas abaixo, a situação ideal na qual as energias são completamente conservadas nos respectivos processos de transformação.

a) Calcule o momento de inércia do carrinho.

b) Estime a velocidade de rotação do carrinho no instante que atinge a superfície rugosa.

c) Estime a velocidade de translação do carrinho no instante que recebe o impacto da haste do ferrolho.

\section{Guia A-3}




\section{APÊNDICE B}

\section{RELATÓRIO DE MINICURSO APRESENTADO.}

\section{Aplicação do trabalho em um minicurso, ministrado na II SELFIS (Semana da Licenciatura em Física), no Instituto Federal do Norte de Minas Gerais.}

Este trabalho foi apresentado em um minicurso, tendo a participação de 22 pessoas, sendo 14 alunos de licenciatura em física do IFNGM- Salinas. Dois alunos de licenciatura de Biologia do IFNGM-Salinas, 4 alunos de licenciatura de física do IFNGM- Januária e 2 professores da rede pública estadual de SalinasMG. Dentre os participantes, 12 integrantes já trabalhavam como professores.

\section{Objetivo do minicurso.}

-Demonstrar as estratégias utilizadas para construir o aparato experimental.

-Compartilhar ideias sobre alguns conteúdos que podem ser abordados com ajuda do arranjo experimental.

-Apresentar as estratégias que foram utilizadas para aplicar o trabalho em sala de aula.

-Propor avaliações e sugestões para melhoramento do produto.

\section{Estratégias do minicurso.}

Apresentei o aparato aos participantes e fiz um relato detalhado dos procedimentos realizados para a construção e a montagem do arranjo experimental.

Destaquei os objetivos gerais da utilização desse arranjo experimental em sala de aula e os objetivos específicos que foram estabelecidos para serem atingidos após a aplicação de uma sequência didática que envolveu 32 alunos do ensino médio. 
Coloquei o aparato para funcionar e destaquei o conteúdo que foi abordado em sala de aula, bem como as estratégias utilizadas para articular um trabalho investigativo e com participação ativa dos discentes. A figura B-1 mostra a trajetória traçada pelo aparato nessa demonstração e a participação dos professores e estudantes do curso de física.

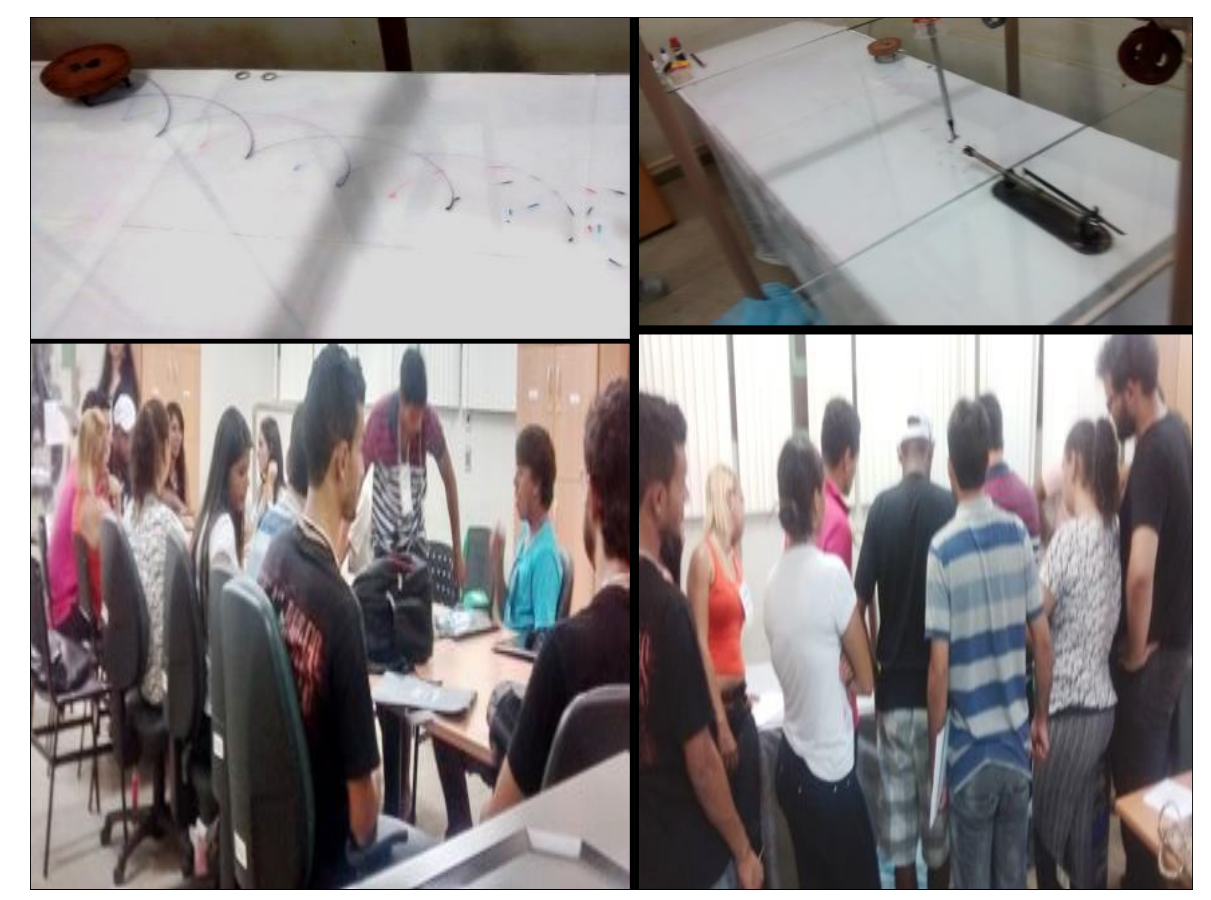

Figura B-1: Apresentação do arranjo experimental no IFNMG-Salinas.

Dando sequência ao trabalho, os participantes receberam as atividades do Guia-2 e de Guia-3, trabalhado em sala de aula, com os alunos do $1^{\circ}$ ano do ensino médio, e foram convidados a discutir sobre o arranjo experimental, a sequência didática utilizada e as estratégias de investigação.

Para finalizar os participantes resolveram e discutiram as atividades do Guia 2 e 3 e fizeram uma avaliação do produto educacional (Figura B-2). 


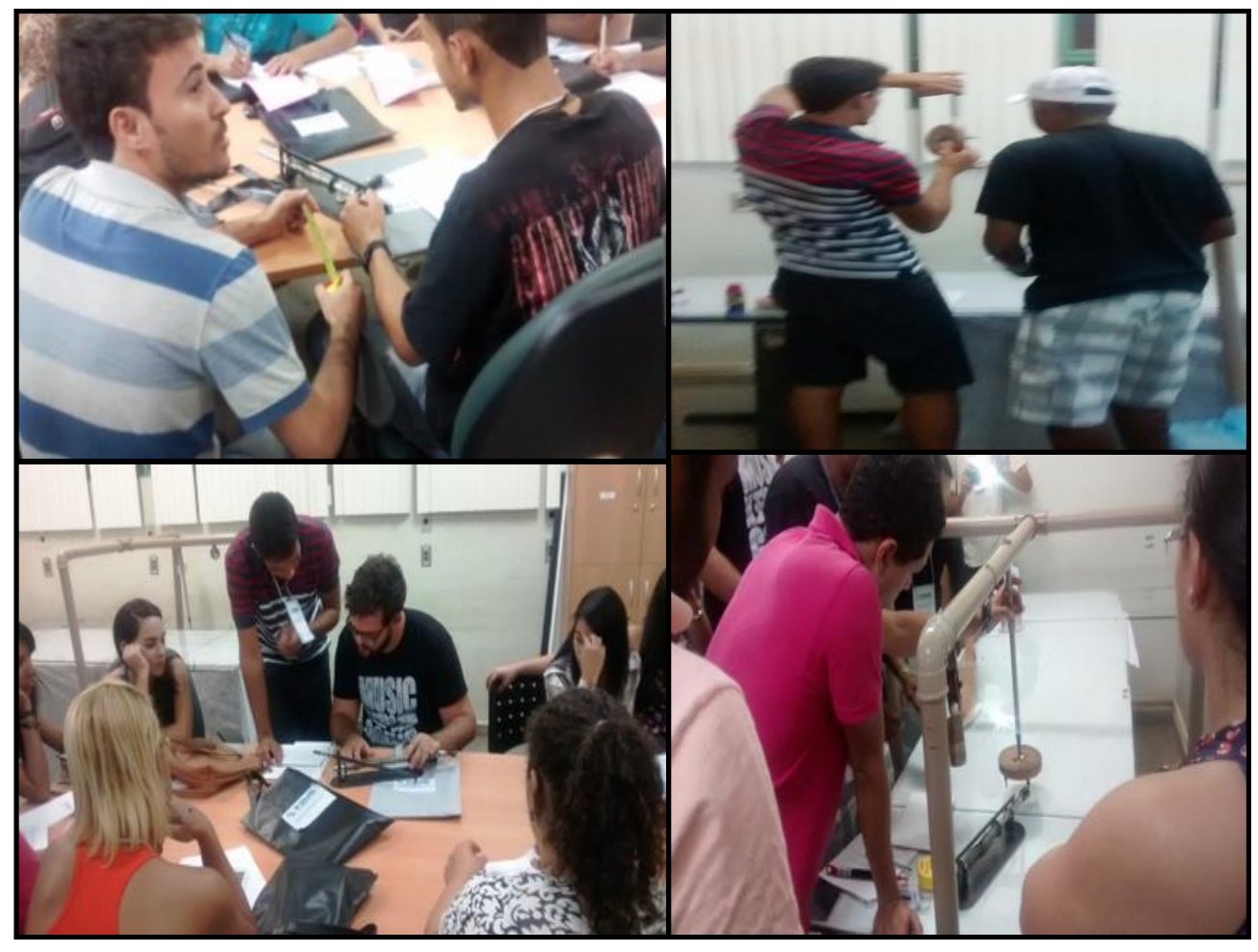

Figura-B-2: Atividades dos participantes do minicurso. 


\section{Questionário avaliativo}

Aos participantes do minicurso. Contamos com a sua ajuda no que tange a responder o formulário abaixo, em relação a sua avaliação diante da aplicação da sequência didática e do arranjo experimental trabalhado pela professora de física Maria da Penha de Laia.

1- Você usaria este arranjo experimental em suas aulas, visando um ensino/aprendizagem mais significativo e menos mecânico?
( ) $\operatorname{sim}$
( ) às vezes
( ) não
( ) sempre que possível

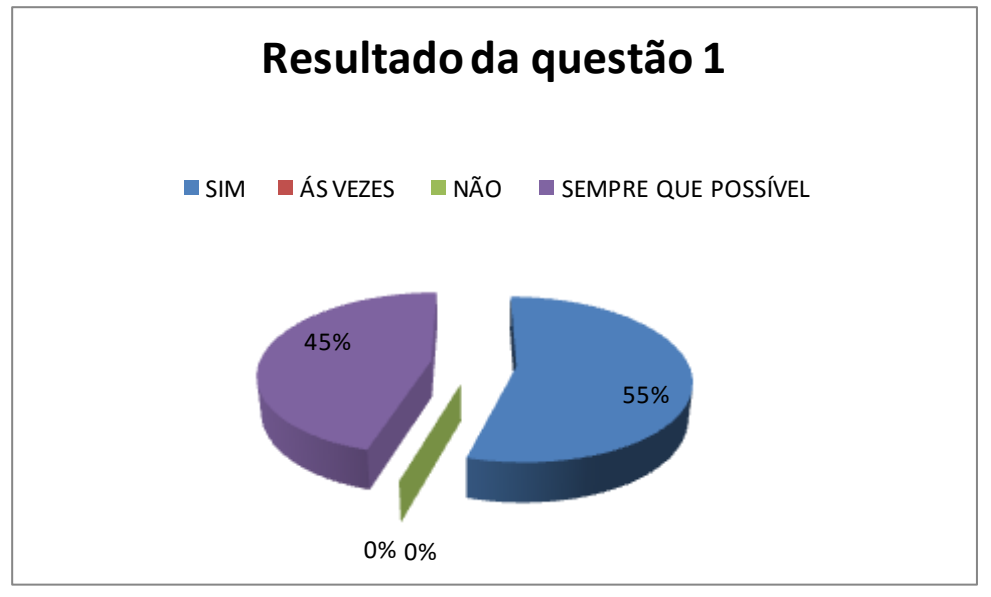

2- Você classifica o método utilizado pela professora para abordar este conteúdo em:

( ) péssimo. ( ) regular. ( ) bom. ( ) muito bom. ( ) excelente

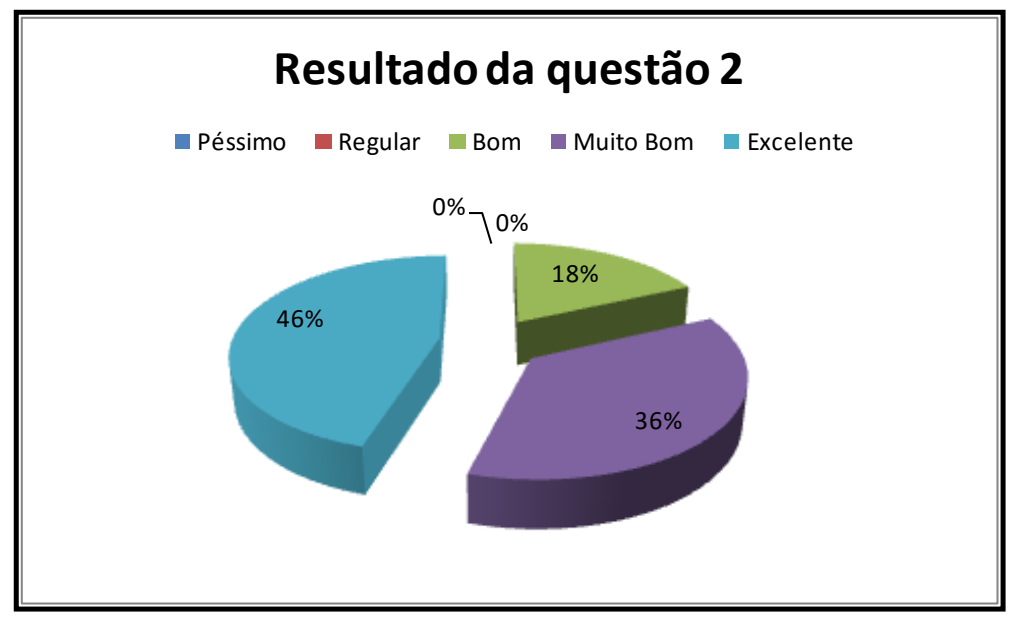


3-O estudo do conteúdo abordado (energia) com a ajuda do aparato é importante para a formação dos alunos.

( ) discordo plenamente. ( ) concordo com restrições.

( ) concordo plenamente. ( ) concordo. ( ) discordo.

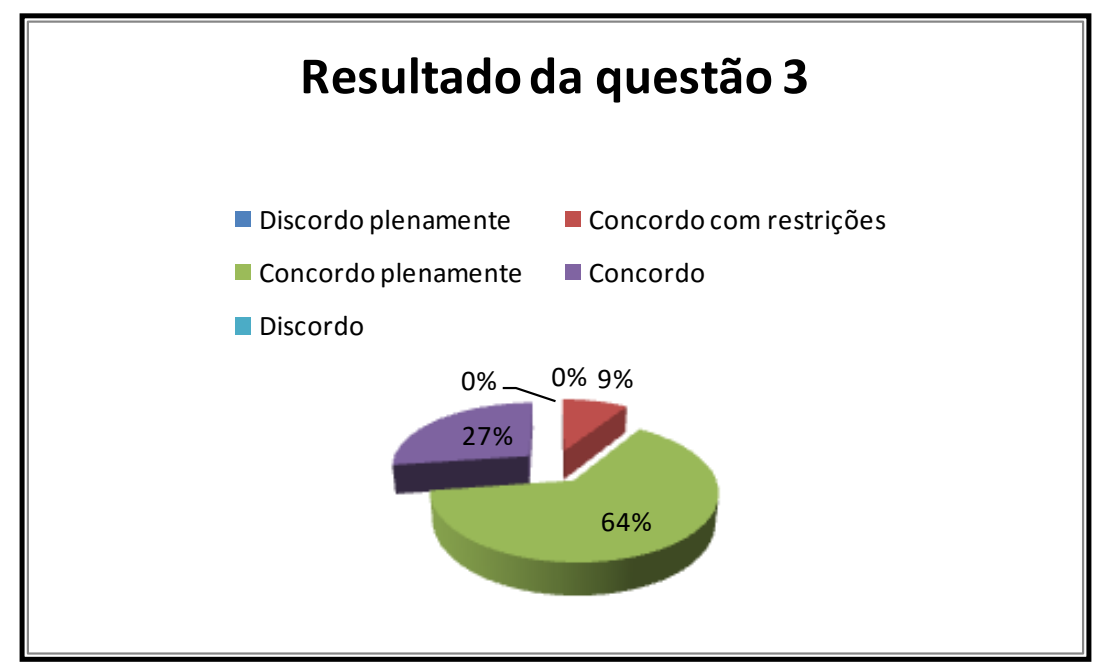

4- Acredito que, se os professores de Física utilizassem com mais frequência, aulas experimentais, onde os alunos pudessem manusear o aparato, fazer medidas, construir tabelas e gráficos e principalmente discutir sobre as observações e resultados encontrados; O ensino/aprendizagem de física tornaria mais fácil.

( ) concordo plenamente. ( ) discordo. ( ) concordo com restrições.

( ) discordo plenamente. ( ) concordo. 


\section{Rsultado da questão 4}
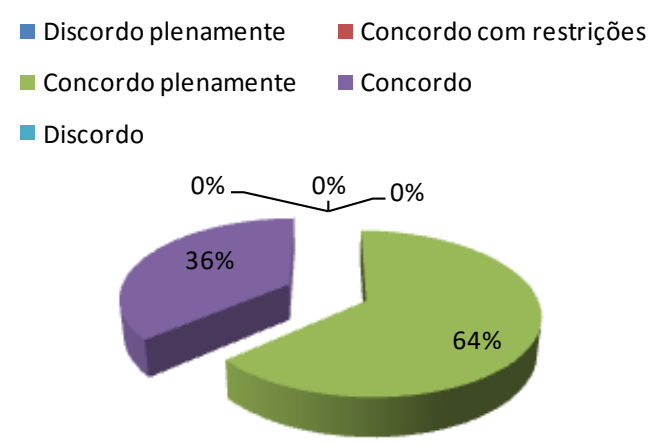

5- Acredito que os alunos participam mais ativamente das aulas, quando os conteúdos são ensinados com ajuda de experimentos e discussões em grupo, desta maneira, a relação entre expressões matemática e conceitos físicos estudados são ensinados dentro de um contexto.
a) discordo.
b) concordo com restrições.
c) discordo plenamente.
d) concordo.
e) concordo plenamente

\section{Resultado da questão 5}
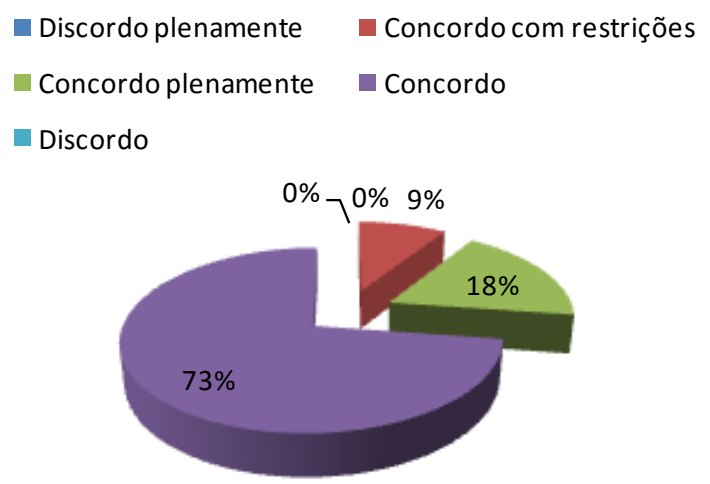
6- O arranjo experimental e a sequencia didática utilizado pela professora, com a participação ativa dos alunos, tem potencial para desenvolver nos discentes um ensino-aprendizagem mais significativos, do que se os mesmos fossem representados por desenhos no quadro e explicado de maneira tradicional.

a) discordo plenamente.

b) concordo com restrições.

c) concordo plenamente.

d) concordo. e) discordo.

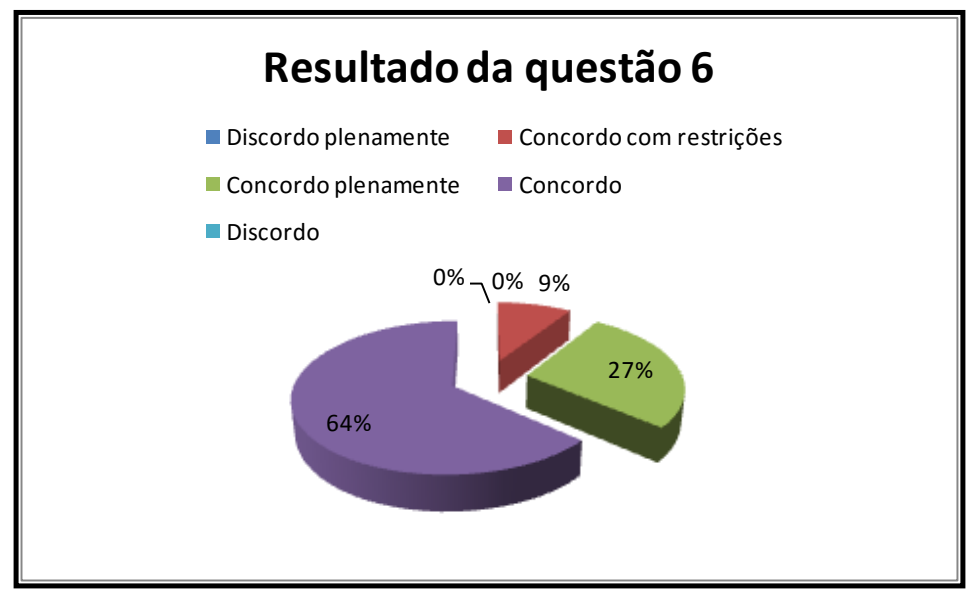

7- O que você mudaria neste arranjo experimental e na sequencia didática?

Respostas:

Tamanho da polia, o pé do carrinho, Nada.

Nada, estava muito interessante a didática apresentada.

Não mudaria nada nem no arranjo experimental nem na sequencia didática utilizada.

Nada, estava muito interessante. 
No arranjo mudaria a base de sustentação e colocava um rolamento em cada parte que roda.

Não mudaria nada, apenas faria revisões diárias no experimento buscando aperfeiçoar.

Em discussão com os colegas, percebemos que o experimento poderia ser construído com materiais um pouco menores e que fosse mais fácil manusear. Com relação à didática, penso que está condizente e poderá ocasionar uma boa eficácia.

8- Você abordaria outros conteúdos com utilização deste aparato?

Respostas:

Acredito que podemos abordar grande parte da mecânica e terá grande eficácia.

$\operatorname{Sim}$

Não

Abordaria a cinemática, a distância do percurso do carrinho do ponto de saída até a chegada. 